UNIVERSIDADE DE SÃO PAULO

FACULDADE DE FILOSOFIA LETRAS E CIÊNCIAS HUMANAS

DEPARTAMENTO DE GEOGRAFIA

ROVAINE RIBEIRO

As Cidades Médias e a Reestruturação da Rede Urbana Amazônica: a experiência de Marabá no Sudeste Paraense

V. 1 


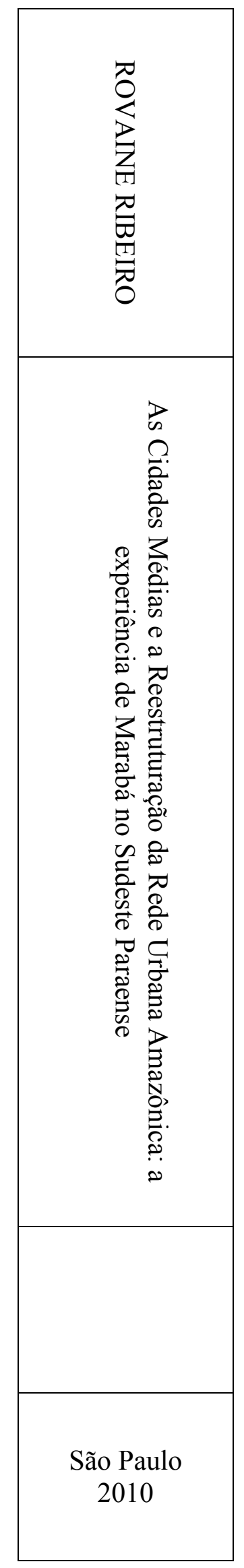




\section{ROVAINE RIBEIRO}

As Cidades Médias e a Reestruturação da Rede Urbana Amazônica: a experiência de Marabá no Sudeste Paraense

V.1

Dissertação apresentada à Faculdade de Filosofia Letras e Ciências Humanas da Universidade de São Paulo para obtenção do título de Mestre em Geografia

Área de Concentração: Geografia Humana

Orientador: Prof. Dr. Hervé Emilien René Théry 
Autorizo a reprodução e divulgação total ou parcial deste trabalho, por qualquer meio convencional ou eletrônico, para fins de estudo e pesquisa, desde que citada a fonte. 
Nome: RIBEIRO, Rovaine.

Título: As Cidades Médias e a Reestruturação da Rede Urbana Amazônica: a experiência de Marabá no Sudeste Paraense

Dissertação apresentada à Faculdade de Filosofia Letras e Ciências Humanas da Universidade de São Paulo para obtenção do título de Mestre em Geografia

Aprovado em:

Banca Examinadora

Prof. Dr.

Instituição:

Julgamento:

Assinatura:

Prof $^{\mathrm{a}}$. Dr ${ }^{\mathrm{a}}$.

Instituição:

Julgamento:

Assinatura:

Prof. Dr. Instituição: Assinatura: 
À Márcio. 


\section{Agradecimentos}

Aos amigos que conheci na cidade onde todos são de algum lugar e lá somos todos "da USP". Àqueles com quem convivi em apenas uma disciplina ou duas (Alberto, Thiago, Lenilton, Edmilson, Marta, Ricardo Gilson, Mariana, entre tantos outros), e especialmente àqueles com quem ainda hoje posso contar (Fabiano e Samarone).

Mais ainda especialmente agradeço aos que me acolheram em suas casas, dividindo as angústias cotidianas de dentro e de fora da universidade (Rodrigo Alta, Fabiano e Tati), e ainda à minha amiga de muitas andanças, Rosi, que como eu vinha de Belém para São Paulo e que compartilhava comigo muitas angústias, e que no caso dela a maior era a falta do açaí e da farinha. À Mayka Danielle, que também compartilhou minha estadia em São Paulo, e que muitas vezes foi minha interlocutora com as burocracias na USP e de suma importância para que pudesse cumprir os "prazos" da FAPESP.

E muito especialissimamente, agradeço aos meus grandes amigos Evandro e Rafael, que sempre foram, sempre são, e desejo que sempre sejam, pessoas que estiveram ao meu lado em minha estadia solitária em São Paulo, aos nossos passeios no Braz, às nossas conversas de madrugada, às nossas brigas pela limpeza da casa, ao caderninho azul, e mais do que isso, à grande amizade que construímos ao longo desse período que desejo que permaneça por todos os anos de nossas vidas.

Aos amigos ainda, àqueles que mesmo à distância foram de suma importância para o conforto de minhas angústias, que nas noites de solidão encontrava pelos espaços virtuais e compartilhava minhas saudades e minhas questões teórico-metodológicas, a Marcos e Mara, muito obrigada. E não poderia deixar de agradecer ao amigo Dawdson, que até na última hora me auxiliou na elaboração de alguns elementos deste trabalho.

Ao meu orientador e amigo professor Hervé Théry, que desde o início sempre confiou e incentivou o desenvolvimento de meu trabalho de pesquisa, antes mesmo de me aceitar oficialmente como sua orientanda, e posteriormente com os contatos com outros professores sobre minha pesquisa para que eu pudesse obter o máximo de diálogo possível com outros pesquisadores sobre meu objeto de estudo. Agradeço a ele ainda, por sua amizade e preocupação durante minha estada em São Paulo.

Às professoras Sandra Lencioni e Mônica Arroyo pelas importantíssimas contribuições para o desenvolvimento deste trabalho através de suas participações em minha banca de exame de qualificação, em que pudemos dialogar sobre meu objeto de estudo e de 
onde parti para a etapa mais difícil deste trabalho, que foi a reelaboração de alguns elementos e as análises da redação final.

À Rede de Estudo sobre Cidades Médias Brasileiras - RECIME, especialmente à professora Maria Encarnação Beltrão Sposito, pelo convite para participar deste importante grupo de pesquisas, e ao professor Saint Clair Cordeiro da Trindade Junior pelo convite a participar do grupo local de Marabá, pesquisa esta que me possibilitou uma maior aproximação com meu objeto de estudo e a experiência de campo por ele conduzida.

À Federação de Órgãos para Assistência Social e Educacional - FASE Amazônia/COMOVA, pelos importantes diálogos durante um ano de pesquisa desenvolvido dentro do projeto "Cidades Pequenas e Médias na Amazônia - construindo uma plataforma socioambiental urbana" no âmbito do Observatório COMOVA, e pelos novos amigos que fiz durante essa experiência.

À Fundação de Amparo à Pesquisa do Estado de São Paulo - FAPESP, pela concessão da bolsa de mestrado e pelo apoio financeiro num período de dois anos, de fundamental importância para a realização desta pesquisa.

E ainda ao CNPq (Conselho Nacional de Desenvolvimento Científico e Tecnológico), uma entidade do governo brasileiro voltada ao desenvolvimento científico e tecnológico, também pelo apoio financeiro através do projeto de pesquisa: "Cidades médias na Amazônia: novos agentes econômicos e novas centralidades urbano-regionais no sudeste paraense", coordenado pelo Prof. Dr. Saint-Clair Cordeiro da Trindade Júnior".

À Prefeitura de Marabá e suas secretarias, bem como a todos os órgãos, entidades e demais informantes, pela concessão de informações imprescindíveis para o desenvolvimento de minha pesquisa.

Por fim, e mais importante, à minha família, que sempre me apoiou para a realização de cada um de meus passos acadêmicos.

E muito mais do que especial, ao meu querido Márcio, pessoa que sempre ao meu lado, contribuiu para que tudo isto pudesse se concretizar, desde minha ida para fazer a seleção do mestrado até a escrita da última linha deste trabalho. 
Não basta abrir a janela

para ver os campos e o rio.

Não é bastante não ser cego

Para ver as árvores e as flores.

Há só uma janela fechada,

e todo mundo lá fora;

e um sonho do que se poderia

ver se a janela se abrisse,

que nunca é o que se vê

quando se abre a janela.

Fernando Pessoa 


\section{Resumo}

RIBEIRO, R. As Cidades Médias e a Reestruturação da Rede Urbana Amazônica: a experiência de Marabá no Sudeste Paraense. 2010. XX f. Dissertação (Mestrado) Faculdade de Filosofia Letras e Ciências Humanas, Universidade de São Paulo, São Paulo, 2010 .

Ao tratarmos da temática da urbanização, e neste caso, da urbanização na Amazônia, devemos levar em conta suas peculiaridades. As cidades devem ser entendidas a partir da maneira como se inserem, em maior ou menor grau na divisão do trabalho, e como historicamente foram afetadas pela divisão inter-regional do trabalho. (SANTOS, 2005) Assim, voltamos nosso olhar para a importância assumida pela cidade de Marabá no sudeste do Pará, tendo em vista sua centralidade na dinâmica de reestruturação socioespacial da região amazônica. Duas questões centrais norteiam esse trabalho: a) qual a importância exercida pela cidade de Marabá, enquanto uma cidade média, na rede urbana e no processo da reestruturação produtiva e espacial, da região amazônica? b) que elementos contribuem para que a cidade de Marabá se torne central nesse processo de reestruturação regional? Dessa forma, buscamos compreender, como, nesse processo de reestruturação da região amazônica, a cidade de Marabá, foi assumindo relevância na dinâmica urbana do sudeste paraense. Entrementes, essa dinâmica urbana regional, nos remete à investigação das possíveis centralidades que algumas cidades da região vêm assumindo nas redes de circulação do território, a partir da reestruturação produtiva regional. Finalmente, nossas preocupações se apresentam como pontos de partida para o entendimento desse conjunto de relações desencadeadas no âmbito da rede urbana regional, em que as especificidades das cidades na Amazônia, a exemplo de Marabá, acabam sendo fundamentais para a compreensão desse processo.

Palavras-chave: reestruturação urbana, cidades médias, Amazônia, Marabá. 


\begin{abstract}
RIBEIRO, R. The Avarage Cities and the Reestructuring of Amazon Urban Network: the experience of Marabá in the southeastern of Pará. 2010. XX f. Dissertação (Mestrado) Faculdade de Filosofia Letras e Ciências Humanas, Universidade de São Paulo, São Paulo, 2010 .

In addressing the theme of urbanization, and in this case, the urbanization in the Amazon, we must take into account their peculiarities. Cities should be understood from the way they fall to a greater or lesser degree in the division of labor, and how historically been affected by inter-regional division of labor. (SANTOS, 2005) Thus, we turn our attention to the importance assumed by the city of Marabá in southeast of Pará, in view of its centrality in the restructuring of sociospatial dynamics of this region. Two central questions guide this work: a) how important is exercised by the city of Marabá, while an average city, the urban network and in the process of productive restructuring and space, the Amazon region? $\mathrm{b}$ ) what factors contribute to the city of Marabá becomes central in this process of regional restructuring? Thus, we seek to understand how, in the process of restructuring the Amazon region, the town of Marabá, assumed significance in the dynamic urban southeastern of Pará. Meanwhile, the urban regional dynamics, leads us to investigate the possible centralities that some cities in the region are taking on the networks of circulation territory, from the regional industrial structure. Finally, our concerns are presented as starting points for understanding this set of relations triggered within the urban area, in which the specifics of the cities in the Amazon, like Marabá, end up being key to understanding this process.
\end{abstract}

Keywords: urban restructuring, avarage cities, Amazon, Marabá. 


\section{LISTA DE SIGLAS}

ACIM - Associação Comercial e Industrial de Marabá

ALPA - Aços Laminados do Pará

ASSIMA - Associação das Indústrias Moveleiras de Marabá

BASA - Banco da Amazônia

BIS - Batalhão de Infantaria de Selva

CDI - Companhia de Desenvolvimento Industrial do Pará

CEFET - Centro Federal de Educação Tecnológica-PA

COHAB - Companhia de Habitação do Estado

COOMIGASP - Cooperativa de Mineração dos Garimpos de Serra Pelada

COOPMASP - Cooperativa da Indústria Moveleira e Serradores de Parauapebas

COSIPAR - Companhia Siderúrgica do Pará

CVRD - Companhia Vale do Rio Doce

DER-PA - Departamento de Estradas de Rodagem do Pará

DIM - Distrito Industrial de Marabá

EAD - Educação A Distância

EMATER - Empresa de Assistência Técnica e Extensão Rural do Estado do Pará

EMBRAPA - Empresa Brasileira de Pesquisas Agropecuárias

FINAN - Fundo de Investimento do Norte

FINOR - Fundo de Investimento do Nordeste

GETAT - Grupo Executivo de Terras do Araguaia - Tocantins

IBAMA - Instituto Brasileiro do Meio Ambiente e dos Recursos Naturais

IBGE - Instituto Brasileiro de Geografia e Estatística

ICMS - Imposto sobre Circulação de Mercadoria e Serviços

INCRA - Instituto Nacional de Colonização e Reforma Agrária

IPI - Imposto sobre Produtos Industrializados

MARGUSA - Maranhão Gusa

MI - Ministério da Integração Nacional

MST - Movimento dos Sem-Terra

MTE - Ministério do Trabalho e Emprego

PEHIS - Plano de Habitação de Interesse Social 
PIB - Produto Interno Bruto

PIC - Plano Integrado de Colonização

PCN - Projeto Calha Norte

PIN - Plano de Integração Nacional

PCN - Projeto Calha Norte

PGC - Programa Grande Carajás

PMM - Prefeitura Municipal de Marabá

PND - Plano Nacional de Desenvolvimento

PNUD - Programa das Nações Unidas para o Desenvolvimento

SEAGRI - Secretaria de Agricultura

SEBRAE - Serviço de Apoio às Micro e Pequenas Empresas

SEIR - Secretaria de Integração Regional

SEMMA - Secretaria Municipal de Meio Ambiente de Marabá

SENAR - Serviço Nacional de Aprendizagem Rural

SEPOF - Secretaria Executiva de Estado de Planejamento, Orçamento e Finanças

SERFHAU - Serviço Federal de Habitação e Urbanismo

SIMARA - Siderúrgica Marabá

SIMASA - Siderúrgica do Maranhão

SINDIFERRO - Sindicato da Indústria de Ferro de Marabá

SINDLEITE - Sindicato das Indústrias de Laticínios do Estado do Pará

SINOBRAS - Siderúrgica Norte Brasil

SNI - Serviço Nacional de Investigação

SUDAM - Superintendência de Desenvolvimento da Amazônia

SUDENE - Superintendência do Desenvolvimento do Nordeste

UEPA - Universidade do Estado do Pará

UFPA - Universidade Federal do Pará 


\section{LISTA DE FIGURAS}

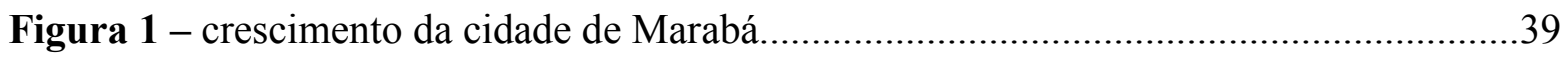

Figura 2 - Planta do Projeto da SUDAM da Nova Marabá.....................................................51

\section{LISTA DE FOTOS}

Foto 1 - Núcleo de Marabá e sua confluência entre os rios Tocantins e Itacaiúnas................30

Foto 2 - Modelo de habitação em Marabá na década de 1950 ..............................................36

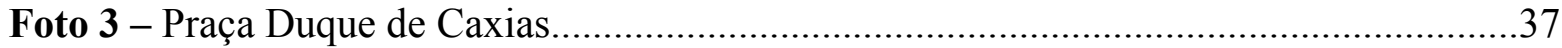

Foto 4 - Enchente na Marabá Pioneira em 1980...................................................................53

Foto 5 - Garimpo nas proximidades de Serra Pelada.........................................................55

Foto 6 - Área de comércio informal no centro do Distrito Marabá Pioneira.........................73

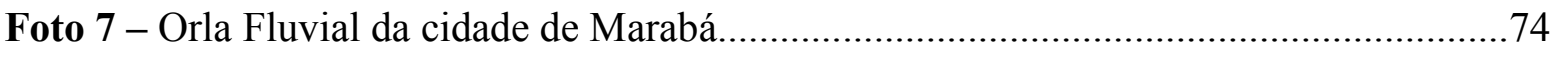

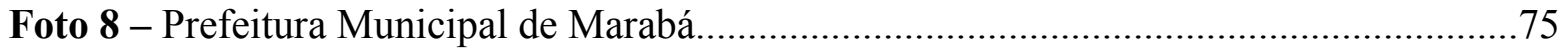

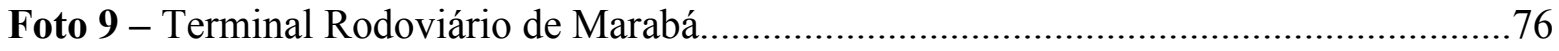

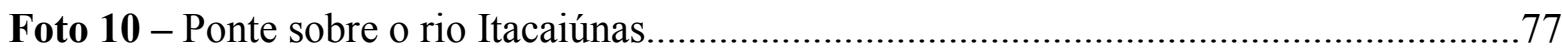

Foto 11 - Loja de departamento no Distrito Cidade Nova.....................................................78

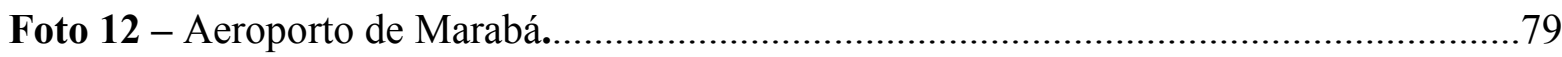

Foto 13 - Pátio da Companhia Siderúrgica do Pará - COSIPAR ............................................80

Foto 14 - Pátio da Siderúrgica Norte Brasil S. A - SINOBRAS........................................... 81

Foto 15 - Caminhões de transporte de Carvão Vegetal..........................................................82

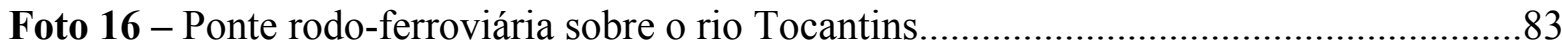

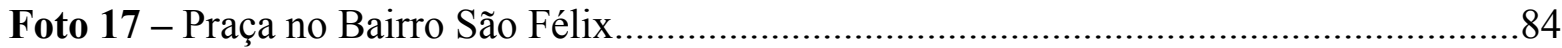

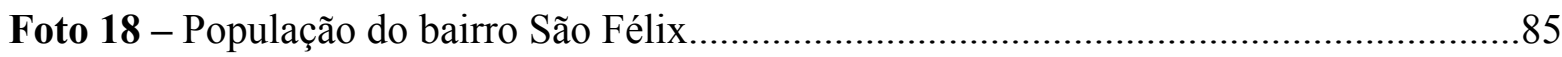

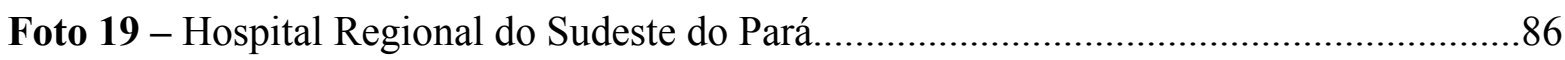

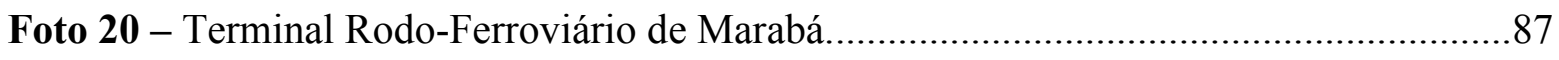

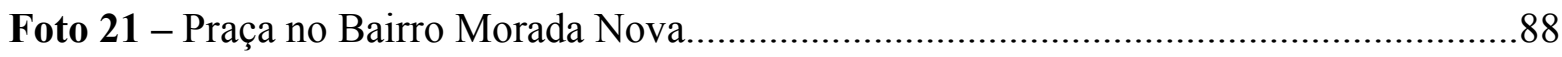

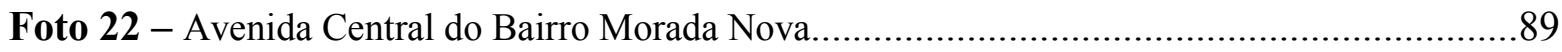




\section{LISTA DE GRÁFICOS}

Gráfico 1 - Participação das Mesorregiões no PIB do Estado do Pará.........................................106

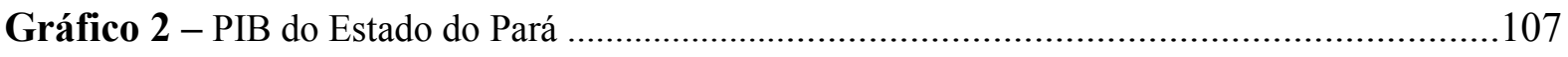

Gráfico 3 - Produto Interno Bruto (VALOR ADICIONADO)................................................116

\section{LISTA DE MAPAS}

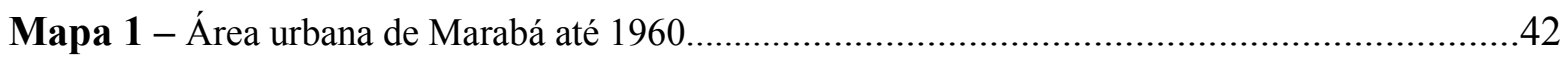

Mapa 2 - Expansão urbana de Marabá a partir de 1970 ..........................................................58

Mapa 3 - Expansão urbana de Marabá após 1990...................................................................68

Mapa 4 - Macrozoneamento Municipal de Marabá..................................................................70

Mapa 5 - Vetores de Expansão Urbana do Município de Marabá..........................................71

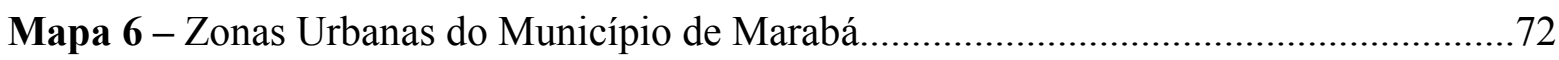

Mapa 7 - localização do Município de Marabá.....................................................................103

Mapa 8 - Vias de circulação no sudeste paraense e a centralidade geográfica da cidade

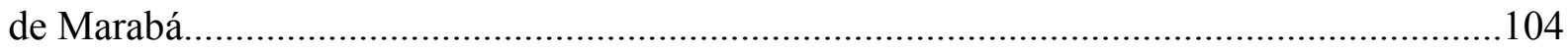

\section{LISTA DE QUADROS}

Quadro 1 - Divisão das regiões de integração em níveis de agregação .66

Quadro 2 - Ranking do PIB dos municípios segundo setores de atividade econômica - Pará, 2002 108

Quadro 3 - Instituições de ensino superior e de formação técnica e seus respectivos cursos no Município de Marabá. 


\section{LISTA DE TABELAS}

Tabela 1 - Distâncias rodoviárias entre Marabá e as principais cidades dentro de sua rede de fluxos 105

Tabela 2 - Movimento Operacional Acumulado do Aeroporto de Marabá (SBMA). 110

Tabela 3 - População, área e densidade demográfica 1980/91/96-2007. 110

Tabela 4 - Produção das Siderúrgicas Instaladas no Distrito Industrial. 117

Tabela 5 - Municípios com maiores repasses de IPI (PRIMEIRO SEMESTRE DE 2008)............118

Tabela 6 - Base econômica do município. 118

Tabela 7 - Evolução do emprego por setor de atividade econômica. 119

Tabela 8 - Arrecadação de ICMS na construção civil por regiões de integração. 121 


\section{SUMÁRIO}

INTRODUÇÃO.

CAPÍTULO I: DO NÚCLEO DO ITACAIÚNAS À MARABÁ POLINUCLEADA.......22

1. A formação socioespacial de Marabá: uma periodização como ponto de partida. .22

1.1. Marabá como centro regional da castanha. .25

1.2. Marabá como base das políticas de desenvolvimento regional da Amazônia Oriental. 43

1.3. Marabá como centro econômico e político do sudeste paraense. .59

1.3.1. O distrito Marabá Pioneira ou Velha Marabá .73

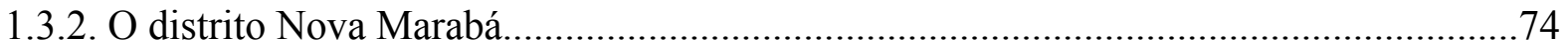

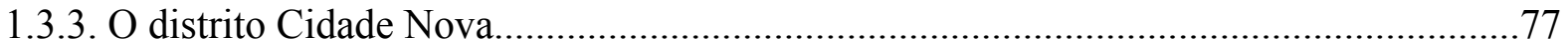

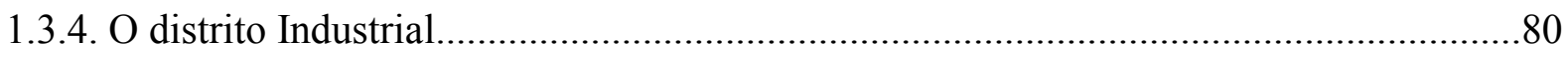

1.3.5. O distrito de Expansão Urbana: São Félix, Km 6 e Morada Nova.................................82

CAPÍtUlO II: A CIDADE MÉdiA E A SUA CENTRALIDADE URBANO-

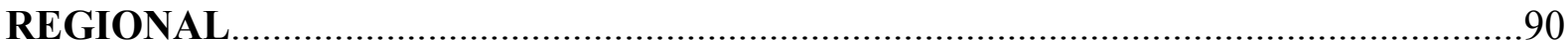

2.1. Reestruturação urbana e cidades médias na Amazônia .......................................90

2.2. Marabá: dinâmica regional e sua área de influência direta..................................102

2.3. As dinâmicas industriais e a centralidade de Marabá no eixo das horizontalidades e das verticalidades

2.3.1. Marabá no centro das transformações socioespaciais. .112

2.3.2. A dinâmica industrial recente e a reestruturação do espaço. 


\title{
INTRODUÇÃO
}

Existem diferentes formas de se chegar à cidade de Marabá, dependendo do caminho e dos meios de locomoção escolhidos para esse fim, pode-se ter uma perspectiva diversa e até antagônica da cidade, pois não se pode dizer que existe apenas uma Marabá, mas várias, condensadas em espaços e tempos diferentes presentes em seus vários núcleos urbanos, um dos elementos que a torna uma cidade singular dentro do universo das cidades com esse nível.

Se existe uma palavra que consegue expressar o mais próximo possível o que seja a cidade de Marabá, essa palavra é entroncamento. Mais do que revelar o cruzamento de vias e artérias, o uso desse termo tem a intenção de expressar o encontro (relações) de diferentes fluxos (de pessoas, de capitais, de informações etc.), com suas histórias e trajetórias, que se imbricam e produzem a diversidade das temporalidades e das espacialidades contemporâneas, sintetizadas em Marabá. Como certa vez expressou Martins (1997), ao tratar da controvérsia existente na compreensão do tempo histórico da frente pioneira e do tempo histórico da frente de expansão:

\begin{abstract}
A bala de seu tiro não só atravessava o espaço entre ele e a vítima. Atravessava a distância histórica entre seus mundos, que é o que os separa. Estão juntos na complexidade de um tempo histórico composto pela mediação do capital, que junta sem destruir inteiramente essa diversidade de situações (MARTINS, 1997, p. 159).
\end{abstract}

Nossa intenção ao apresentar essa citação de Martins (1997) é a de simplesmente dizer que não é possível analisar Marabá em si mesma, pois o que ela é resulta da dinâmica em que esteve envolvida a Amazônia oriental, especialmente, o sudeste paraense ao longo da história. Dessa forma, podemos dizer de imediato, que não se pode fazer uma pesquisa sobre a cidade em questão, sem discutir as transformações regionais e seu papel nesse processo, uma vez que é esse cruzamento que exprime o que é a cidade de Marabá, o resultado de dinâmicas intraurbanas e interurbanas, que nos impõe a necessidade fazer uso de uma abordagem relacional para sua compreensão.

Desta maneira, buscamos analisar o processo de urbanização na Amazônia e as transformações de sua rede urbana, especialmente em sua porção oriental, e o papel desempenhado por Marabá enquanto uma cidade média nesse processo. Assim, partindo das discussões sobre "reestruturação urbana" e "reestruturação das cidades" (SPOSITO, 2000; 2004), e "economia política da urbanização" e "economia política da cidade", procuramos 
mostrar as transformações econômicas ocorridas na Amazônia oriental, principalmente no sudeste, e o papel de centralidade assumido por Marabá.

Para entender a dinâmica urbana e os processos socioespaciais da cidade, é necessário compreendê-la a partir de suas relações com o mundo exterior, seja o seu entorno ou não, mas também, de suas especificidades intra-urbanas. Assim, é fundamental tratar a idéia de rede urbana, entendida à maneira de Corrêa (2006), como "o conjunto de centros urbanos funcionalmente articulados entre si" (CORRÊA, 2006, p.43).

Dessa forma, os processos são, todavia, também desencadeados, pela forma como, na divisão territorial do trabalho, o capital e seus agentes atuam nos espaços regionais, e nesse sentido, é que devemos levar em conta as dinâmicas socioespaciais anteriores a essas ações, ou seja, entender aquilo que Santos (2000) denominou de formações socioespaciais. E assim, compreender também as cidades em seu sentido mais íntimo, a partir da idéia de que trata Sposito (2004) da morfologia intra-urbana, entendida não apenas como as formas urbanas, mas todos os elementos internos e também externos que compõem o interior dos núcleos urbanos em sua relação com a região em que se inserem.

Deve-se ressaltar que ao longo dos anos o capital tem transformado o espaço a partir de suas "necessidades" produtivas. A organização espacial da produção, através das divisões (territorial e regional) do trabalho desse modo, tem se voltado à criação de vantagens locacionais, isto é, a criação de infra-estruturas, isenção fiscal e políticas de crédito, criadas pelo Estado, para atrair o grande capital e seus agentes para lugares em que este ainda não se encontra em sua plenitude, tal como demonstra Santos (2002).

Foi dessa forma que a região Amazônica a partir da década de 1970, principalmente, passou por transformações decorrentes do II Plano Nacional de Desenvolvimento (II PND), que tinha por objetivo a desconcentração industrial, e que desencadeou certa "modernização" na região. Essa modernização se refletiu na mudança da estrutura produtiva da região sudeste do Estado do Pará, e nesse caso, também na cidade de Marabá, que passa de uma estrutura voltada ao extrativismo (caucho e castanha) para a produção mineral e agropecuária. E nesse processo, a ação do Estado transformou não apenas a paisagem regional com a criação dos grandes projetos mínero-metalúrgicos (Programa Grande Carajás, com os projetos Ferro Carajás, Albrás-Alunorte, Hidrelétrica de Tucuruí entre tantos outros), e dos projetos de assentamento e colonização agrícola (criação das agrovilas, agrópolis e rurópolis), bem como a criação de infra-estruturas de suporte a esses projetos, como a abertura de rodovias, ferrovias, portos e aeroportos, a criação de cidades planejadas das companhias, as company towns. Ao mesmo tempo, essa reorganização espacial, com um expressivo crescimento 
populacional, gerou a periferização das grandes cidades e das cidades de médio porte, alterando ainda, um conjunto de relações até então existentes na região, um modo de vida atrelado ao rio, ao tempo lento, e passa para uma vivência da estrada, da rapidez, ao espaço da circulação mais fluida. (SANTOS, 2002)

Diante do exposto, voltamos nosso olhar para a importância assumida pela cidade de Marabá no sudeste paraense, tendo em vista sua relevância para a reestruturação socioespacial da dinâmica urbana da região amazônica. Assim, duas questões centrais norteiam esse trabalho: 1) Qual a importância exercida pela cidade de Marabá, enquanto uma cidade média, na rede urbana e no processo da reestruturação produtiva e espacial, da região amazônica? 2) Que elementos contribuem para que a cidade de Marabá se torne central nesse processo de reestruturação regional?

Tendo essas questões como premissa, procuramos, de modo geral, analisar como no processo de reestruturação urbana da região amazônica, em sua porção oriental, a cidade de Marabá, enquanto uma cidade média foi assumindo uma centralidade na dinâmica urbana do sudeste paraense. E, especificamente buscamos entender de que forma a cidade de Marabá assume uma relevância diante da reestruturação urbana regional na Amazônia oriental e mais especificamente no sul e sudeste paraense; analisar de que maneira a cidade de Marabá acaba convergindo para si a circulação da produção regional e como esse processo acaba transformando sua dinâmica socioespacial, buscando identificar ainda, os elementos que contribuem para que a cidade assuma uma centralidade no processo de reestruturação da rede urbana regional da Amazônia Oriental.

Neste sentido, duas hipóteses foram levantadas. A primeira refere-se à centralidade que Marabá assume como centro dinamizador e centralizador da dinâmica socioespacial do sudeste paraense, em virtude de ter sido alvo de políticas públicas voltadas para a Amazônia Oriental, o que levou à sua emergência como principal cidade comercial e política do sudeste paraense, apresentando-se assim, como fundamental para o estabelecimento da lógica competitiva do capital e de seus agentes na rede urbana regional do sudeste paraense. À segunda, diz respeito aos elementos que contribuem para esta centralidade que a cidade de Marabá exerce na rede urbana regional do sudeste paraense, e nesse caso, dois elementos principais se apresentam. O primeiro refere-se ao fato de alguns centros urbanos tradicionais voltarem a se tornar centrais a partir da abertura de rodovias; o segundo elemento é que estes centros acabaram sendo influenciados pela nova dinâmica regional propiciada pelas ações do Estado a partir da criação de programas de desenvolvimento para a Amazônia, que reforçaram 
a relativa independência de cidades como Marabá aos centros maiores, dando a essa rede certa complexidade.

Foi partindo desse segundo elemento de análise que tomamos a dinâmica industrial da cidade como referência para a abordagem das principais mudanças evidenciadas em Marabá, tanto do ponto de vista produtivo, quanto no seu aspecto socioespacial de sua centralidade urbano-regional no sudeste paraense.

Levando em conta os aspectos anteriormente elencados, a presente pesquisa, em princípio, procurou enfatizar informações de caráter qualitativo, buscando compreender, a partir da análise da relação estabelecida entre Marabá e as cidades com as quais estabelece relações, até que ponto os fluxos de capitais, bens e serviços que dela partem, bem como seu papel político e econômico, influenciam na dinâmica das demais cidades da região em que está inserida. Desse modo, se fez necessário seguir os seguintes procedimentos de pesquisa, expressos em fases distintas: a primeira fase teve como preocupação central estabelecer um ajustamento teórico com vista à interpretação da problemática construída, tendo estabelecido um levantamento bibliográfico de cunho teórico e outro, referente à produção acadêmica sobre o processo de produção do espaço, urbanização, rede urbana e formação de cidades médias de modo geral e, em específico, sobre esses processos na Amazônia, com destaque para Amazônia Oriental, e mais particularmente no sudeste paraense.

$\mathrm{Na}$ segunda fase da pesquisa buscou realizar um levantamento documental voltado especificamente para a região do Sudeste Paraense. Neste momento, foram realizados levantamentos de dados secundários referentes a indicadores sócio-econômicos, demográficos e espaciais, encontrados em publicações do Instituto Brasileiro de Geografia e Estatística (IBGE) - Censo Demográfico (IBGE, 2001), Informações Municipais (IBGE, 2001a), Indicadores Sociais Municipais (IBGE, 2002) -, do Governo do Estado do Pará, através de sua Secretaria Executiva de Estado, de Planejamento, Orçamento e Gestão (SEPOF) e da Secretaria Executiva de Desenvolvimento Urbano e Regional, do Programa das Nações Unidas para o Desenvolvimento (PNUD - Índice de Desenvolvimento Humano), do Ministério da Integração Nacional (Secretaria de Políticas de Desenvolvimento Regional, Secretaria de Programas Regionais etc.), do Instituto de Colonização e Reforma Agrária (INCRA) e da Prefeitura Municipal de Marabá.

Numa terceira fase foram realizados dois trabalhos de campo na cidade em estudo, a fim de buscar informações mais aproximadas da realidade em questão. No primeiro trabalho foram realizados levantamentos de informações secundárias em secretarias da prefeitura, em associações, tais como, associação comercial e industrial, em instituições de ensino superior 
públicas. Ainda nesse primeiro momento foi realizado o georreferenciamento e os registros fotográficos de todos os núcleos urbanos (Marabá Pioneira, Nova Marabá, Cidade Nova, São Felix, Morada Nova e KM-06), mais o distrito industrial, que compõe a cidade. No segundo trabalho de campo, foi realizado o levantamento de informações primárias, através da realização de entrevistas gravadas, junto às instituições públicas (federal e municipal), as associações (do setor formal e informal), os sindicatos (patronais e dos trabalhadores), as indústrias siderúrgicas e as empresas comerciais e de prestação de serviços.

Como última fase da pesquisa foi realizada a sistematização e a análise do material levantado, de maneira a possibilitar a redação final da dissertação.

Por fim, o trabalho ficou estruturado em dois capítulos, sendo que, no primeiro deles buscamos fazer uma discussão teórica sobre formação econômica e social, com base em Godelier (1986), e formação socioespacial, a partir das contribuições de Santos (2005). A intenção em fazer uso dessas discussões teóricas, era a de ter uma referência capaz de mostrar a diversidade dos agentes que produzem o espaço intra-urbano e regional, e que ao mesmo tempo fosse capaz de expressar a complexidade da estrutura espacial da cidade, de maneira a entendê-las como resultado de processos reveladores de tempos diferentes.

Ainda nesse primeiro capítulo fez-se uma discussão teórica sobre periodização, fundamentada em Corrêa (2006), e mostrou-se como ela se processou na realidade estudada. Assim, a formação socioespacial de Marabá foi trabalhada em três grandes períodos: o primeiro, correspondendo ao período em que a cidade esteve sob a égide do capital comercial e mercantil, associado às atividades extrativas do caucho, da castanha e do cristal de rocha, e que configurou a primeira estrutura urbana de Marabá, manifesta na chamada Marabá Pioneira ou Velha Marabá; o segundo período relaciona-se ao papel que a cidade desempenhou como base logística das políticas públicas voltadas ao desenvolvimento regional e que fez com que ela se expandisse muito além do núcleo pioneiro, dando origem a dois novos núcleos principais, Nova Marabá e Cidade Nova. Esse período tem dois momentos distintos, o primeiro deles em que a cidade serviu de base para a política de colonização agrícola do INCRA, e, o segundo momento, em que funcionou como base para a integração econômica regional, por meio de grandes empreendimentos econômicos, tais como, o projeto de ferro de Carajás, o pólo siderúrgico e o garimpo de Serra Pelada. O terceiro período referese a fase atual da formação, que é marcado consolidação da atividade industrial, não somente aquela definida pela dinâmica da globalização como a siderurgia, mas também aquelas de caráter mais regional, como as indústrias da construção civil, leiteira e moveleira, pela maior presença de instituições federais e estaduais que tem a cidade como sede regional, pela forte 
presença de políticas de desenvolvimento regional pensadas e executadas a partir da instância estadual e não mais federal de governo, como no período anterior, a presença do capital imobiliário nacional, a ação dos movimentos sociais do campo e da cidade que tem Marabá como base de sua organização, entre outras dinâmicas. O principal resultado desses novos processos tem sido uma maior modernização da cidade, em outros termos, a cidade passa a apresentar internamente uma maior densidade de atividades comerciais e de serviços modernos, uma melhoria de sua infra-estrutura urbana e uma maior presença de empreendimentos imobiliários horizontais e verticais. 


\section{CAPITULO I}

\section{DO NÚCLEO DO ITACAIÚNAS À MARABÁ POLINUCLEADA}

\section{A formação socioespacial de Marabá: uma periodização ${ }^{1}$ como ponto de partida}

A discussão acerca da formação socioespacial de Marabá, nos remete à duas questões, primeiro, à sua conceituação enquanto categoria analítica no campo da ciência geográfica, e em segundo lugar, à utilização da mesma no âmbito da análise desse trabalho.

A categoria formação socioespacial, tem como ponto de partida a noção de formação econômica e social proposta por Marx, para o qual, de acordo com Godelier (1986) a realidade é um processo contínuo, em que:

(...) toda a realidade não toma forma senão no interior e no fim de um processo particular que dura um certo tempo e lhe confere o seu aspecto, características e propriedades específicas; lembrar que esses processos têm, eles próprios as suas condições de existência e não se reproduzem senão na medida em que tais condições se reproduzem: tais foram, parece-nos, as intenções de Marx quando escolheu a palavra 'formação' para exprimir o seu pensamento. (GODELIER, 1986, p.133)

A formação, parte ainda da relação da forma com outros elementos que constituem sua acepção e que revelam a dinâmica da realidade, quais sejam, processo, estrutura, aparência e essência. Nesse sentido, a forma que especifica um conteúdo - a forma social - tem um aspecto ativo na medida em que, mal começa a existir, já desempenha um papel ativo no desenvolvimento daquele conteúdo. Além disso, para o autor, não é apenas importante estudar

\footnotetext{
${ }^{1}$ A idéia de periodização, conforme aponta Corrêa (2006), "tanto na periodização da organização espacial como nas grandes fases da história, o pesquisador defronta-se com a presença simultânea de heranças do passado e de elementos do futuro. A periodização da organização espacial é, neste sentido, a história espacializada, espacializando-se e a se espacializar. A possibilidade de periodização da organização espacial inclui tanto a organização global como uma organização específica, a rede urbana ou um determinado lugar, uma cidade, por exemplo. A periodização espacial é a reconstrução do tempo espacial, isto é, a colocação em evidência dos momentos diferenciados que caracterizam o processo de elaboração da organização espacial. Na Amazônia, esta diferenciação de tempos espaciais é muito marcante no âmbito da rede urbana. Tão marcante que se pode falar em segmentos 'velhos', que possuem um tempo espacial longo, e segmentos 'novos', como exemplifica-se com as cidades ribeirinhas, de um lado, e as cidades e os embriões urbano, de outro, que surgiram recentemente ao longo dos grandes eixos rodoviários que rasgaram a Amazônia" (CORRÊA, 2006, p. 184). As relações entre periodização e escala espacial são, por sua vez, semelhantes àquelas em que em uma dada escala de tempo, divide-se a história... Semelhantemente, é possível considerar a periodização da organização espacial da rede urbana brasileira, fazendo emergir a rede urbana da Amazônia; em outra escala, a rede urbana da Amazônia pode ser periodizada evidenciando-se os tempos em relação aos quais sua organização espacial fez-se diferenciada" (CORRÊA, 2006, p. 183-185).
} 
a forma acaba dos fenômenos do real, mas, sobretudo, as suas mudanças e seu desenvolvimento. A análise do real deve ainda, fazer a distinção entre a forma real e forma aparente, em que se deve considerar a sua estrutura interna para além da forma visível sob a qual os fenômenos aparecem espontaneamente à consciência dos indivíduos, que são por eles permeados e se tornam prisioneiros de sua aparência. É dessa maneira, que na interpretação de Godelier (1986), a respeito da formação econômica e social, para Marx:

A noção de 'formação social' designa portanto a totalidade das relações sociais (económicas e outras) que compõem uma certa forma de sociedade; mas em si mesma esta noção nada diz sobre a natureza real desta forma, quer dizer, sobre a natureza da articulação [Gliederung] (...) o que a noção designa é um campo de investigações teóricas, o mais difícil que existe nas ciências sociais, visto que o pensamento científico se propõe, depois de ter analisado a realidade social concreta nas suas determinações mais simples e, por conseqüência, as mais abstractas, e de ter descoberto as relações e as articulações recíprocas, recompor, 'reproduzir pela via do pensamento o concreto(...), que é concreto por ser a síntese [Zusammenfassung] de múltiplas determinações e unidade, portanto, do múltiplo'”(p. 137) "Uma 'formação económica (e) social' não é uma realidade que se explique na experiência imediata. É uma realidade que deve ser reconstruída pelo pensamento científico, que não aparece portanto senão no fim, e não antes, do trabalho de análise científica.

A noção de 'formação social' designa portanto a totalidade das relações sociais (económicas e outras) que compõem uma certa forma de sociedade; mas em si mesma esta noção nada diz sobre a natureza real desta forma, quer dizer, sobre a natureza da articulação [Gliederung] que existe entre essas relações sociais (...) O que a noção designa é um campo de investigações teóricas, o mais difícil que existe nas ciências sociais, visto que o pensamento científico se propõe, depois de ter analisado a realidade social concreta nas suas determinações mais simples e, por conseqüência, as mais abstractas, e de ter descoberto as relações e as articulações recíprocas, recompor, 'reproduzir pela via do pensamento o concreto (...), que é concreto por ser a síntese [Zusammenfassung] de múltiplas determinações e unidade, portanto, do múltiplo'. (GODELIER,1986, pp.136-137)

Santos (2005a), em seus estudos sobre a ciência geográfica, se apropria da categoria "formação econômica e social", no intuito de dar a ela um aspecto analítico geográfico para a compreensão dos processos socioespaciais. Dessa maneira, acrescenta a essa análise a dimensão espacial, no sentido de contribuir para a construção de uma abordagem geográfica que compreendesse o espaço a partir das relações sociais e sua historicidade. Assim, para ele, "é preciso definir a especificidade de cada formação, o que a distingue das outras, e, no 
interior da FES, a apreensão do particular como uma fração do todo, um momento do todo, assim, como o todo reproduzido numa de suas frações" (SANTOS, 2005a, p. 25).

Ainda conforme o autor, a formação social compreenderia uma estrutura produtiva e uma estrutura técnica. Refere-se, nesse sentido, a uma estrutura técnico-produtiva que se expressa geograficamente através da distribuição da atividade produtiva. E desse modo, a localização dos sujeitos, das atividades e das coisas no espaço, é explicada, de um lado, pelas necessidades "externas", àquelas referentes ao modo de produção "puro", e de outro lado, pelas necessidades "internas", que são representadas pela estrutura de todas as buscas e pela estrutura de classe, a formação social em sua essência (SANTOS, 2005a).

Para ele, a história dos momentos de produção é também a história da sucessão de formas criadas através da sucessão de diversos modos de produção. A história da "formação social" é a que se refere à superposição de formas criadas pela sucessão destes modos de produção, da sua complexidade sobre "seu território espacial". Desse modo, o valor de cada objeto geográfico no interior da FES, não pode ser atribuído por seu valor próprio, no que se refere à herança de um determinado modo de produção anterior, mas sim como formaconteúdo, que se realiza, pelo modo de produção tal como ele se constitui na e pela formação social (SANTOS, 2005a).

Desse modo é que reconhecemos nesta análise, elementos essenciais para o estudo e compreensão da realidade da região amazônica e em particular da cidade de Marabá, e nesse sentido fez-se a opção metodológica pela categoria "formação socioespacial", de maneira a desenvolver a análise de seus processos socioespaciais, ainda que existam outras categorias analíticas, a exemplo da "formação territorial", proposta por Moraes $(2000)^{2}$.

Esta opção deriva da compreensão de que não há história fora do espaço e nem sociedade a - espacial; que a formação econômica e social contempla as diversas esferas da vida de uma sociedade e expressa a unidade da continuidade e da descontinuidade no seu desenvolvimento histórico; que nos permite entender a relação entre modo de produção e formação econômica e social, em que o primeiro é a possibilidade de realização, a segunda é a possibilidade realizada; o modo de produção é a abstração, a formação é indissociável do concreto; a interdependência entre modo de produção, formação econômica e social e espaço, tendo em vista que o modo de produção é determinado não apenas historicamente, mas

\footnotetext{
${ }^{2}$ Esta abordagem é melhor desenvolvida pelo autor em sua análise sobre a formação do território brasileiro, para o qual a noção de território, é um dos elementos da análise geográfica enquanto totalidade. Sendo, pois, uma escala, mas também um espaço que possui uma historicidade específica, e para sua compreensão enquanto, três dimensões são fundamentais: a econômica, a política e a cultural.
} 
também espacialmente; das especificidades no interior de uma FES, em que estas são associadas às especificidades espaciais; o modo de produção só se concretiza por meio de uma base territorial historicamente determinada, que revela a diferença entre os lugares, nesse sentido, múltiplos arranjos espaciais que resultam da articulação entre as necessidades externas (do modo de produção) e necessidades internas (definidas pela FES) - nessa perspectiva não há oposição entre história e estrutura, dado que o modo de produção só se realiza na e pela formação econômica e social; e ainda que o termo socioespacial deriva da idéia de que não há separação entre sociedade e espaço tanto no plano teórico como no real. Por fim, o conceito marxista de FES aplica-se a uma sociedade, o que não necessariamente corresponde a um Estado-Nação, de outro modo, o conceito de formação socioespacial de Santos possibilita de um lado, considerar o espaço como uma dimensão constitutiva do momento histórico e não apenas palco, e por outro, o múltiplo dimensionamento da análise, considerando as escalas geográficas em que os processos e dinâmicas se desenvolvem desigual e combinadamente (SPOSITO, 2004).

\subsection{Marabá como centro regional da castanha}

Por mais que a origem de Marabá seja imputada como tendo ocorrido no final do século XIX, é possível verificar, segundo Almeida (2002), que os rios Tocantins e Araguaia já eram conhecidos desde muito antes, quando bandeirantes paulistas realizavam expedições para essa região, quando aventureiros singravam esses rios em busca de drogas do sertão e quando padres jesuítas com o objetivo de catequizar e atrair tribos indígenas para suas missões próximas a Belém.

Esse fato indicado por Almeida pode ser confirmado por EMMI (1999), quando afirma que várias incursões à região próxima a Marabá tinham sido realizadas por colonizadores e seus descendentes que, fundaram no trecho entre Belém e Marabá, diversos núcleos populacionais, dentre os quais Cametá (1635), Baião (1694), Mocajuba (1853) e Alcobaça (atual Tucuruí), que funcionavam como entrepostos ligados à navegação do rio Tocantins - já que esta era muito difícil, devido à existência de sucessivos trechos encachoeirados - e que desenvolviam práticas agrícolas, principalmente de subsistência.

De acordo com Velho (1972), foi a partir do Sul, mas principalmente do Leste que a região foi sendo penetrada. A expansão da frente pecuarista, que em meados do século XVIII atingiu o sul do Maranhão, numa região denominada de Sertão dos Pastos Bons foi responsável pela ocupação efetiva do Tocantins, pois de Pastos Bons saíam expedições de criadores de gado para todas as direções, que ao estabelecer "invernadas", foram dando 
origem a diversos núcleos populacionais ao longo do Tocantins, principalmente entre o Maranhão e Goiás. Dentre os núcleos surgidos nesse período o autor destaca: Riachão (1808), Porto da Chapada (1811 - origem da cidade de Grajaú), Carolina (1810) e Boa Vista do Tocantins (1825).

Foi essa expansão pecuarista da frente pastoril do Maranhão e do norte de Goiás que atingiu no final do século XIX o sul e o sudeste paraense, promovendo a formação do burgo do Itacaiúnas em 1895. Este tem sua origem relacionada a lutas partidárias nacionais ${ }^{3}$ e a conflitos políticos e religiosos entre facções partidárias em Boa Vista do Tocantins em 1892, conforme aponta Emmi (1999).

Com o fim do conflito da Boa Vista, o grupo perdedor (florianistas), abandou o local seguindo em subgrupos para o Leste e para o Norte. Para o Norte foram criadores e comerciantes ligados ao Coronel Carlos Gomes Leitão, descendo o Tocantins em direção ao Itacaiúnas, onde estabeleceram uma colônia agrícola, o Burgo de Itacaiúnas. (EMMI, 1999) A população em 1896 era de 222 habitantes, sendo 55 famílias, em sua maioria vaqueiros, agricultores, comerciantes e antigos proprietários de terras de Goiás e do Maranhão, além de indígenas das matas próximas. As primeiras atividades além da agricultura eram o extrativismo da castanha em virtude da abundância do produto naquela localidade e em suas proximidades, a criação de gado e ainda a extração do látex. Esta última atividade acabou alterando as relações no burgo: a agricultura deu lugar ao extrativismo; primeiro período de migração para o local (maranhenses, goianos e cearenses), mudando ainda o primeiro núcleo de ocupação para outro, na confluência do Tocantins e do Itacaiúnas ${ }^{4}$ devido à facilidade para o escoamento da produção e para as trocas de mercadorias (EMMI, 1999).

Ainda de acordo com a autora, o fim da colônia é dado pela transferência para esta outra área denominada então de povoado de Marabá, sendo um centro eminentemente comercial, com uma economia baseada no extrativismo e secundariamente com uma pequena agricultura.

A outra frente fundamental para o surgimento de Marabá está relacionada ao extrativismo da borracha, que já vinha se desenvolvendo em outras regiões da Amazônia, e que a partir de 1897 alcança a região do Tocantins, ainda que a área não fosse das mais privilegiadas nesse aspecto. Para Velho (1972), os fundadores do Burgo tiveram muita

\footnotetext{
${ }^{3}$ Segundo Emmi (1999, p. 29), “... os anos que se seguiram imediatamente à Proclamação da República, foram profundamente marcados pelas rivalidades entre partidários do Marechal Deodoro da Fonseca e do Marechal Floriano Peixoto. O Estado do Pará não podia ficar alheio à dinâmica nacional."

${ }^{4}$ Tocantins e Itacaiúnas são os dois rios que margeiam a cidade de Marabá, formando um triângulo, conforme figura 4.
} 
dificuldade em manterem-se fiéis à criação e à agricultura, pois com a descoberta do caucho os objetivos iniciais foram se transferindo da agricultura para a extração da goma. Nas palavras de Emmi (1999):

O caucho veio assim contribuir para o despovoamento do Burgo uma vez que a facilidade de comunicação levou os caucheiros a se localizarem na ponta de terra situada entre o Tocantins e o Itacayuna, e aos comerciantes a armarem seus barracões que forneceriam as mercadorias necessárias para o internamento na mata. (EMMI, 1999, p. 36)

Antes de avançar nessa discussão do novo núcleo surgido na confluência dos rios Tocantins e Itacaiúnas, é importante, ainda que sem aprofundamento, falar do período áureo da economia da borracha Amazônia, cuja frente alcançou a área que posteriormente daria origem a Marabá.

De acordo com Corrêa (2006), o período que se estende de 1850 a 1920 caracteriza-se pelo boom do extrativismo da borracha que promoveu o revigoramento, tanto da economia, quanto da rede urbana da região. Dentre as condições por ele indicadas, com base na obra de Roberto Santos, para a expansão do extrativismo da borracha, destacam-se: a forte e crescente demanda externa de borracha; a superação do problema do sistema de transporte e da escassez da mão-de-obra e; a oferta de capitais para o financiamento da produção. A primeira está relacionada à crescente demanda externa de borracha, decorrente de sua utilização na indústria, principalmente pneumáticos. Dessa forma, a Amazônia se inseriu na divisão internacional do trabalho por meio da produção de borracha, que chegou a contribuir com $90 \%$ da produção mundial em 1890. A segunda condição se realizaria no que se refere ao sistema de transporte, pela criação da Companhia de Navegação e Comércio do Amazonas, pertencente ao Barão de Mauá, que depois foi substituída pela Amazon Steamship Navegation Company Limited, de capitais ingleses; já no que se refere à escassez de mão-de-obra, a solução encontrada foi a imigração, principalmente de nordestinos, que contribuiu para um grande aumento da população regional. A terceira condição foi realizada, tanto com capital estrangeiro, quanto com capital nacional, sendo que este se vinculou ao financiamento das importações de bens de consumo e instrumentos de trabalho, e àqueles em atividades vinculadas à produção e ao transporte da borracha.

Quanto à rede urbana, Corrêa (2006) destaca, de um lado, a expansão da própria rede urbana e o revigoramento demográfico e econômico dos núcleos preexistentes e, de outro lado a intensificação por meio de "aviamento", das relações entre os núcleos de povoamento. Além disso, enfatiza a transferência de riquezas para as cidades de Belém e Manaus, observadas por meio dos melhoramentos urbanos. 
Para Machado (1999) é nessa fase da borracha que se localiza a origem da urbanização regional, antes desse período, as missões religiosas e as pequenas vilas e fortificações concebidas pelos portugueses e construídas com o trabalho indígena ainda que fossem funcionais ao domínio territorial, quase nada tinham a ver com a gênese do urbano na região ${ }^{5}$. Segundo ela o surgimento de novas aglomerações e o desenvolvimento, ainda que precário, da forma urbana estão relacionados à espacialmente extensiva cadeia comercial de exportação da borracha natural e a importação de bens de consumo: a hierarquia urbana regional é dada pela posição dos núcleos dentro da rede de comércio, constituindo, assim, uma "protourbanização".

Munidos dessa caracterização geral a respeito do período áureo da borracha, podemos então voltar à discussão do extrativismo do caucho para Marabá.

De imediato três fatos importantes sobre a extração na área do Itacaiúnas são destacados por Velho (1972). O primeiro deles refere-se ao fato de que desde o início da fundação do burgo de Itacaiúnas, a extração já se constituía em tentação para os colonizadores como uma atividade viável e rentável; o segundo fato diz respeito a que mesmo no auge do período da borracha, a exploração na área ainda era bastante modesta; o terceiro fato diz respeito a que a castanha mesmo sendo um produto mais modesto disputava a preferência dos extrativistas.

A certeza da existência do caucho na área atraiu um intenso fluxo de pessoas de diversas partes, especialmente do Maranhão e do norte de Goiás, remanescentes ainda da frente pecuarista; e ainda dos Estados do Piauí, Ceará, Paraíba, Pernambuco, Bahia entre outros.

Conforme aponta Velho (1972), desde o início aparece a figura do comerciante. Numa região em que a terra não constituía bem escasso, não aparecia a figura do latifundiário como "poderoso por excelência". Nas regiões mais distantes, o bem escasso eram o capital e os meios de comercialização. O comerciante tinha interferência em dois momentos, primeiro, na venda dos produtos necessários para que os trabalhadores pudessem permanecer por longo período na mata para a extração, e depois, na compra do produto coletado por esses trabalhadores.

Por essa razão, Velho (1972) afirma que Marabá surge como iniciativa de comerciantes, para ele:

\footnotetext{
${ }^{5}$ Nesse ponto a autora diverge de outros analistas do processo de urbanização da Amazônia, principalmente Corrêa (2006).
} 
Sua fundação é um caso exemplar a demonstrar que mesmo em região onde o meio parece dominar de modo tão absoluto o homem, a influência geográfica só pode ser entendida quando mediatizada pelas forças sociais envolvidas, as quais podem ter origem bastante remota e transcendente em relação à própria área. (VELHO, 1972, p. 42)

Diferentemente do Burgo, a principal função de Marabá era o comércio. O núcleo rapidamente prosperou e acabou se tornando centro de polarização e atração para uma grande área, por um lado no sentido de atração populacional e, por outro em virtude do abastecimento, tendo em vista as particularidades da atividade extrativa (VELHO, 1972).

$\mathrm{O}$ aspecto urbano de miséria opunha-se ao esplendor e riqueza da borracha. Porém, o crescimento de sua importância, fez com que em seguida casas melhores fossem aparecendo mais distantes da beira do rio e aos poucos fossem dando origem a uma pequena cidade (VELHO, 1972).

A importância do comércio para Marabá vincula-se também à sua posição geográfica estratégica, que segundo Dias (1958) passa a se fortalecer nesse momento atraindo comerciantes de várias áreas da região, a exemplo de Francisco Coelho, maranhense vindo do Grajaú, que:

(...) viera estabelecer-se no povoado, verificou a importância, para o comércio do caucho, que teria o pontal formado pela conjunção do Itacaiúnas com o Tocantins. Para lá mudou sua casa de comércio, instalando-se em uma barraca, a que deu o nome de Marabá. Isto a 7 de julho de 1898. Dêste modo pôde facilmente comerciar com os caucheiros; a êstes era mais interessante vender logo o produto a ter que remar contra as correntezas do Tocantins. (DIAS, 1958, p.393)

De acordo com Dias (1958), Marabá é um típico exemplo de como o fator posição pode influenciar na vida de um aglomerado urbano. Ainda que o sítio urbano apresentasse condições de adversidade decorrentes em grande medida das enchentes que sempre assolaram essa parte da cidade. A autora deixa claro que a cidade sempre voltava - passado o período das chuvas e das enchentes - para o mesmo lugar, devido o papel privilegiado por ele assumido no extrativismo.

Segundo ela nesse período do extrativismo do caucho a cidade foi crescendo à montante dos rios, pelas vantagens da topografia do sítio. A margem do Tocantins ganhou em importância pela maior presença de casas comerciais e armazéns de depósito de castanha, devido principalmente à presença do "porto", que tornava essa parte da cidade mais valorizada. 
Ainda sobre o sítio urbano de Marabá, Almeida (2002) aponta que este era condicionado aos acidentes geográficos, tendo em vista que se tratava de uma península cercada pelos rios Tocantins e Itacaiúnas, sendo por isso, uma área sempre afetada pelas enchentes, o que de acordo com a autora, foi um dos motivos que levaram, posteriormente, ao desmembramento da cidade em mais dois núcleos: o do Amapá na margem esquerda do rio Itacaiúnas e o de São Félix, na margem direita do Tocantins. (Foto 1)

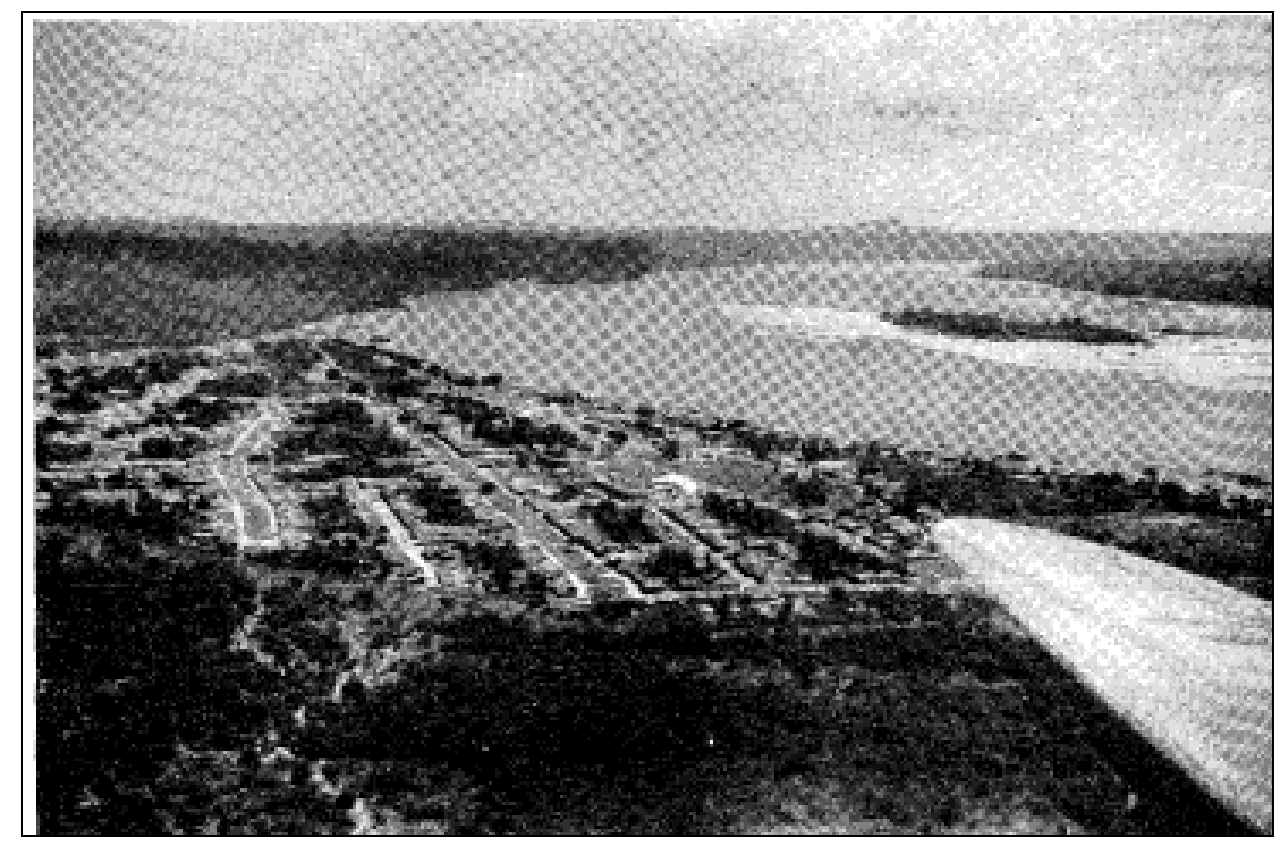

Foto 1: Núcleo de Marabá e sua confluência entre os rios Tocantins e Itacaiúnas Fonte: Dias, 1958.

Comentário: A foto 1 representa os aspectos físico-geográficos que permitiram a Marabá surgir como entreposto para a circulação de produtos e pessoas na região.

Dias (1958) chega mesmo a afirmar que a rede hidrográfica constituiu e ainda constitui a principal via de povoamento da cidade, além de proporcionar o desenvolvimento econômico regional. O Itacaiúnas e seus tributários produziam a quase totalidade da produção que era exportada pelo Tocantins. Nesse sentido, Marabá funcionava como um ponto estratégico, tanto para a produção quanto para a circulação, pois, a cidade tinha um domínio absoluto sobre as regiões circunvizinhas, uma vez que tanto o Araguaia, Tocantins, quanto o Itacaiúnas, escoavam a produção na altura da cidade. Além disso, a influência de Marabá alcançava o baixo Tocantins (até Baião) e o médio Tocantins (atingindo o norte de Goiás e o oeste do Maranhão). Em virtude dessa posição entre os rios Tocantins e Itacaiúnas, local estratégico para o domínio do escoamento da produção regional 
O crescimento econômico da cidade, em virtude da exploração e comércio do caucho, segundo Almeida (2002), fomentou o interesse pela emancipação, que ocorreu no ano de 1913, através da Lei Estadual $\mathrm{n}^{\mathrm{o}} 1.278$ de 27 de fevereiro do respectivo ano, pelo desmembramento do município de São João do Araguaia. Em 1923, conforme estabelecido pela Lei no 2.207, Marabá foi alçada à condição de cidade.

A forte dinâmica desencadeada pelo caucho, porém, teve seu declínio, primeiro em função da forma de extração da seiva que levava ao sacrifício das árvores e assim contribuindo para o desaparecimento das áreas de caucho, e em segundo lugar, pela brusca queda da demanda pela borracha, no período pós I Guerra Mundial, fator esse que ratificou a estagnação dessa atividade econômica na região (ALMEIDA, 2002).

Segundo Corrêa (2006), o período que vai de 1920 a 1940, aproximadamente, se caracteriza pela decadência do extrativismo da borracha, pelo aumento da dívida pública interna e externa, pelo refluxo populacional para as áreas de origem, pela relativa autarcização dos seringais, e pela diminuição absoluta da população das pequenas cidades. É importante destacar que mesmo nesse período de crise geral, algumas áreas restritas da região alcançaram prosperidade urbana, decorrente da produção da juta - o caso das cidades do médio Amazonas, principalmente Santarém -, e da castanha-do-pará - na região do Tocantins e Itacaiúnas, com destaque para a cidade de Marabá, que se tornou o centro de comércio mais importante dessa área.

Interpretação semelhante a essa é encontrada em Velho (1972), que afirma que a queda da borracha fez com que a Amazônia caísse num período de depressão, observado principalmente na sua dinâmica populacional que apresentou entre 1920 e 1940 uma taxa de crescimento inferior ao crescimento vegetativo, o que tornou a região uma área de repulsão. Deve-se destacar, no entanto, que essa estagnação não foi uniforme em toda a imensa região, pois é possível verificar em diversas áreas da Amazônia a busca por produtos de exportação com o intuito de minorar os efeitos da crise, não resta dúvida, porém, que a exploração da castanha concentrada especialmente no médio Tocantins tenha sido a que logrou maior sucesso, transformando Marabá no segundo município do Estado.

Para Dias (1958), a exploração da castanha foi reativada em 1920 e a partir dessa época sua influência foi fundamental na vida do município de Marabá, apresentando reflexos profundos também na economia de todo o médio Tocantins e Araguaia. A cidade de Marabá, que desde o período do caucho se constituiu num mercado consumidor dos produtos agrícolas e pecuários do sertão, intensificou ainda mais a importação dessas regiões. Deve-se destacar que ao mesmo tempo com o avanço de sua praça comercial constituiu um porto de 
intercâmbio intenso com todo o médio Tocantins. Além disso, a cidade se configurou num centro de redistribuição de produtos para Goiás e Maranhão; produtos que chegavam de Belém, Rio de Janeiro, São Paulo, Recife e Fortaleza

De imediato é importante afirmar que a exploração da castanha se dava em moldes oligárquicos, em que o poder dessa oligarquia estava assentado inicialmente sob a égide do capital mercantil e que progressivamente se firmou a partir da apropriação da terra, facilitada pela posição exercida na hierarquia administrativa que permitiu o exercício da dominação, traduzida em relações de exploração de tipo paternalista sobre caucheiros, castanheiros, barqueiros, tropeiros e trabalhadores da castanha, que assumiam posições diferenciadas na estrutura social local (EMMI, 1999).

De acordo com Velho (1972) a infraestrutura que tinha sido montada na época da borracha (de 1898 a 1919 aproximadamente) foi gradativamente sendo transferida para a exploração da castanha, o que foi possível devido ao fato de serem atividades econômicas fundamentalmente do mesmo tipo. Este fato levou o autor em questão a considerar que não se trata de um novo período, mas sim de um novo sub-período ou de uma fase dentro do mesmo período, que exigiu apenas alguns ajustes, mas que manteve na essência as mesmas relações de trabalho, de modo que "a Marabá da borracha já é, em grande parte, contemporânea da Marabá de hoje [a Marabá da castanha]" (VELHO, 1972, p. 48).

Podemos dizer que, num primeiro momento (até o início da década de 1920), a exemplo do que ocorreu com o caucho, a extração da castanha era realizada de maneira livre, no sentido da organização do trabalho, que se dava sem a dependência de um "patrão" e na base puramente familiar, e do acesso a terra. Aos poucos essa extração livre foi se tornando difícil, pois o Governo acabou transferindo os principais castanhais de acesso facilitado para particulares, que os exploravam ao seu bel prazer, e que obrigou os coletores autônomos a buscar áreas muito distantes onde se pudesse exercer a colheita livre (VELHO, 1972; EMMI, 1999). O trabalho "livre" também não escapou da exploração comercial, pois os indivíduos que desejavam sair à cata da castanha poderiam ser "aviados" pelos comerciantes, dentre os quais, ao lado dos nacionais, os de origem sírio-libanesa, que os aprisionavam em sua teia de relações.

Mas como os abutres seguem a caravana, um 'regatão', ou negociante ambulante, também vai, após cada longa fila de montarias, em viagem para o castanhal. Instala seu depósito de mercadorias não distante de um grupo de barracas, e lá, como uma aranha no centro de sua teia, à espera, por traz de sua bateria de garrafões cheios de cachaça, cercada de algumas peças de pano vistoso, de molhos de tabaco, de saccas de sal, latas de kerosene e até 
caixas de inferior cerveja, attrae os apanhadores de castanha que não podem deixar de se tornar sua presa. Pouco a pouco todas as colheitas se acumulam no armazem preparado junto à sua loja. No fim da estação, os pobres caboclos estão endividados, sentido-se felizes se podem para se quitarem, ajudar o regatão, tornado 'patrão' a carregar suas embarcações e conduzi-las até o porto mais próximo. (LE COINTE apud EMMI, 1999, p. 69)

Antes de discutir a fase do monopólio da exploração da castanha, queremos destacar dois elementos importantes para o entendimento desse processo: o primeiro refere-se ao processo produtivo da castanha, que compreende a colheita e o beneficiamento primário voltado a exportação, em Belém, e aos serviços necessários no período entressafra (conservação de estradas, limpeza de igarapés, conservação de pastagens, de roçados e de armazéns). A coleta do ouriço ocorre no período do "inverno", o tempo das chuvas, que contribuem para a queda das castanhas e facilitam o seu transporte por via fluvial nas várias etapas de comercialização, uma vez que os igarapés enchem e os trechos mais perigosos do Tocantins tornam-se mais fáceis de serem transpostos (VELHO, 1972). No início do período os castanheiros voltam-se apenas à coleta dos ouriços, transportando-os em paneiros ${ }^{6}$ para um local em que se encontram o restante do grupo de coletores; depois desse momento passa-se ao corte dos ouriços reunidos e segue a catação dos frutos que continuam a cair (EMMI, 1999). De acordo com essa autora:

As sementes retiradas dos ouriços são amontoadas em depósitos rústicos sem cobertura, apenas para impedir o contato com o chão, até que sejam transportadas para a sede do castanhal. O transporte da castanha é feito em tropas de burros dos depósitos para o barracão. Ao chegar ao barracão, ela é levada em paneiro e passada na água corrente do igarapé, separando-se as sementes podres. A castanha armazenada no barracão, sede do castanhal, sofre novo transporte para o centro primário de comercialização, a cidade de Marabá, onde a castanha é armazenada. (EMMI, 1999, p. 70)

$\mathrm{O}$ segundo elemento refere-se ao financiamento da produção da castanha. O financiamento dos castanhais é conhecido na região como "aviação", ou seja, o "camarada" recebe um adiantamento de aviação (alimento, roupas, tabaco, terçado, querosene e dinheiro), necessários para seu abastecimento no período em que estiver envolvido na coleta da castanha. Esse adiantamento, por sua vez, será descontado na produção por ele realizada, ficando também pactuado a venda da castanha ao próprio "patrão", que na maioria das vezes, para financiar o castanheiro também vendia a produção antecipadamente ao comércio (não

\footnotetext{
${ }^{6}$ Paneiros são cestos de palha trançados, muito utilizados na região para o transporte de frutos, tais como: açaí, pupunha, castanha etc.
} 
raramente esse "patrão" era também comerciante de Marabá) (DIAS, 1958). Segundo a autora:

A exploração da castanha estando intimamente dependente da cidade de Marabá, faz com que para ela seja escoada tôda a produção do médio Tocantins. E êste é o motivo porque a exportação em sua grande totalidade se faça pelo "porto" de Marabá, que durante a safra tem intenso movimento. (DIAS, 1958, p. 84)

Para fugir dessa cadeia de exploração os castanheiros procuravam manter-se durante a safra o mais auto-suficiente possível, de modo a evitar a contração de dividas junto aos barracões do castanhal. Sua alimentação constituía-se em grande parte da caça, da castanha e do seu leite, do açaí, do cupuaçu entre outros. Ainda assim, tinham que recorrer ao barracão em busca dos produtos que não poderiam ser adquiridos na floresta tais como, munição, querosene, sal, açúcar, café, fumo, farinha etc.; a não ser que estivessem próximos a Marabá, o que se tornava cada vez mais difícil (VELHO, 1972). Esse autor destaca ainda que as condições de trabalho eram as piores possíveis, os trabalhadores ficavam suscetíveis à chuvas, às doenças, aos animais e ao choque com grupos indígenas. Viviam em abrigos muito simples, uma cobertura de palha sobre estacas onde armavam suas redes. Muitas vezes o que ganhavam não era o bastante para cobrir as dívidas contraídas no aviamento e no barracão, em alguns casos ainda ficavam devendo, o que os obrigavam a ficarem presos num regime de "servidão por dívidas". A alternativa era fugir, mas tinha o risco de serem pegos e assassinados pelos capangas do patrão. Quando conseguiam obter saldo positivo, esse dinheiro era freqüentemente gasto em farras (numa espécie de compensação pelos meses de isolamento), quando não era tomado pela polícia local. De qualquer forma, esse recurso constituía boa parte do numerário proveniente da castanha, gasto na cidade de Marabá, pois os lucros dos comerciantes e arrendatários eram investidos ou gastos fora da cidade.

Ainda falando sobre o financiamento da produção, Velho (1972) destaca o papel da cadeia de exploração da castanha em que no topo estão os grupos importadores no estrangeiro, principalmente Inglaterra e Alemanha, com destaque para o porto de Liverpool, e durante a segunda Guerra Mundial os Estados Unidos se tornaram praticamente o único mercado, especialmente Nova Iorque e Los Angeles. No segundo escalão da cadeia encontram-se os grupos exportadores de Belém, que eram cerca de seis (6) e que mantinham o oligopólio sobre essa atividade e que descarregavam as oscilações dos preços do mercado externo nos grupos de Marabá, que por sua levavam o processo de extorsão dos castanheiros às últimas conseqüências. O terceiro elo da cadeia era formado pelos comerciantes de Marabá e/ou arrendatários de castanhal, que buscavam manter certa unidade, o que era favorecido pela 
associação de castanheiros e pela Maçonaria, que tinham papel fundamental na reunião e integração da elite local, o que não significa dizer que não existiam rivalidades e conflitos, seja no aspecto econômico ou político. Era muito comum a invasão de castanhais por arrendatários de outros castanhais, também era comum a compra de castanha retirada clandestinamente de algum castanhal por comerciantes, o que levava algumas vezes à ocorrência de assassinatos. $\mathrm{Na}$ base da cadeia encontra-se o elo mais frágil, os castanheiros, que estavam submetidos a toda sorte de exploração e violência.

$\mathrm{Na}$ fase do monopólio da exploração da castanha, denominada por Emmi (1999) de “oligarquia do Tocantins", a autora destaca que a economia extrativa da castanha que permitiu o controle do trabalho e da produção, também irá possibilitar a formação de uma sociedade local em que os grupos representantes do capital mercantil passaram a exercer a apropriação econômica, seja pela extração do lucro comercial, seja pela exploração dos trabalhos nos castanhais, oferecendo condições para o exercício da dominação política local, um mecanismo de controle sobre a apropriação da terra nas áreas de castanhais. Nas palavras da autora:

\begin{abstract}
Alguns desses grupos locais que não eram apenas comerciantes financiadores, e que passaram também a 'donos' ou 'arrendatários' de castanhais, detinham também o controle das comunicações por meio dos rios. Eram, na maioria dos casos, proprietários dos barcos usados no transporte da castanha; controlavam não só o comércio da castanha, como também grande parte do comercio de gêneros alimentícios. Por meio da apropriação da terra, passaram a controlar toda a atividade produtiva. (EMMI, 1999, p.75)
\end{abstract}

Nessa fase do monopólio é importante ressaltar três aspectos: primeiro, o processo de concentração da propriedade pela oligarquia latifundiária mercantil expropriou pequenos e médios arrendatários de castanhais; segundo, os coletores livres, aos poucos, vão perdendo suas áreas de Servidão Pública ou "castanhais do povo", tanto pela apropriação de fato por donos de castanhais, quanto por dispositivos legais. A apropriação não se deu de forma pacífica, uma vez que existem registros do uso da violência pelas oligarquias, mas também reações de defesa por parte dos expropriados, que não reconheciam os novos donos. Além desses fatores, o desaparecimento desses castanhais do povo está relacionado ao crescimento da cidade, à expansão da agropecuária e à apropriação pelos chefes políticos locais. Terceiro, os indígenas que alem de terem seus territórios invadidos, tiveram também seus castanhais arrendados para particulares e em alguns casos foram transferidos em função das atividades econômicas desenvolvidas pelos grupos dominantes (EMMI, 1999). 
Para se ter uma idéia mais precisa da importância da castanha para a cidade de Marabá. Deve-se ressaltar, de acordo com Dias (1958), que ainda na economia do caucho Marabá não passava de um abarracamento de palha, e que essa situação teria permanecido não fosse pela descoberta da castanha, que viriam a modificá-la completamente a partir do desenvolvimento dessa atividade econômica. (Foto 2)

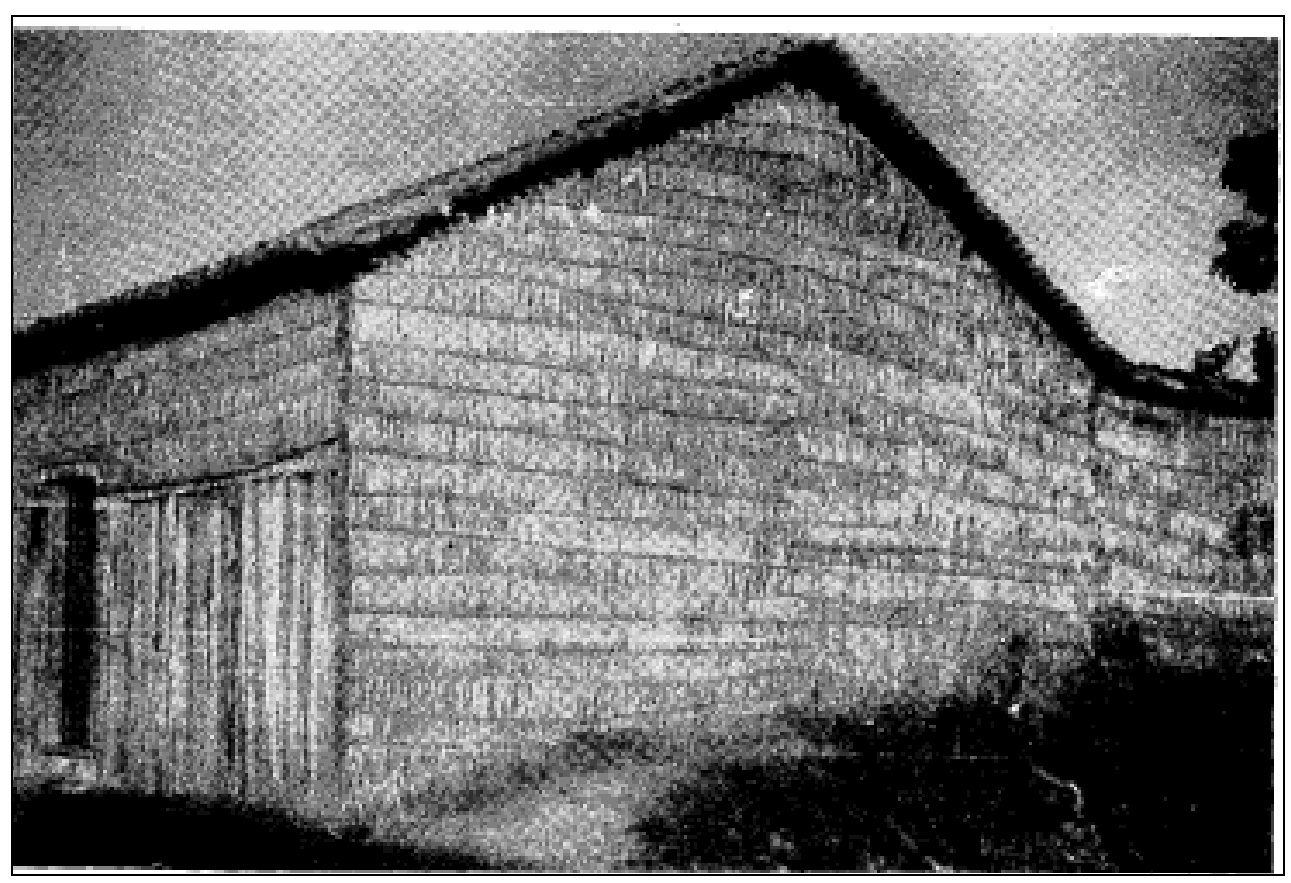

Foto 2: Modelo de habitação em Marabá na década de 1950

Fonte: Dias, 1958.

Comentário: Conforme aponta a autora, o material comumente usado nas residências, no período anterior à castanha, eram: palha, taipa, madeira e tijolo para as paredes; palha e telha para a cobertura; madeira, ladrilho, tijolo, cimento ou de terra batida. O material era todo produzido em Marabá ou na região próxima, à exceção do cimento, isso em virtude da produção das olarias do Itacaiúnas, que era toda empregada em Marabá, fator que contribuiu para a substituição da palha como material de construção (DIAS, 1958).

Dias (1958), destaca que para o estudo da expansão urbana de Marabá, deve-se levar em conta as enchentes que assolaram o município, tendo em vista que elas marcam nitidamente as fases de mudanças e de desenvolvimento da cidade. A autora demonstra que o crescimento da cidade ocorreu no sentido da montante dos rios Tocantins e Itacaiúnas pelas facilidades e vantagens de sua topografia. A margem do Tocantins ganhou importância à medida que iam se estabelecendo casas comerciais e depósitos de castanha, isso em virtude do "porto" para o escoamento da produção, o que levou a uma crescente valorização dos terrenos nessa área da cidade. 
No período de 1929 a 1947 a cidade mudou sua fisionomia, com o surgimento de ruas paralelas à Avenida Antônio Maia ${ }^{7}$ e com a criação de largas avenidas, além disso, passava a perder uma característica até então muito marcante, a instabilidade de sua população, o que se refletia nas casas de palha que ainda existiam, e foram aos poucos sendo substituídas por outras de tijolos (DIAS, 1958).

O crescimento da cidade acompanhou as margens do Tocantins, entretanto agora para uma região mais alta, onde raramente era afetada pelas enchentes, inclusive com a transferência das instituições públicas para essa área - as instituições foram alocadas na avenida 5 de julho, atual Praça Duque de Caxias - , em detrimento da extremidade do pontal, onde as enchentes causavam transtornos todos os anos (DIAS, 1958). (Foto 3)

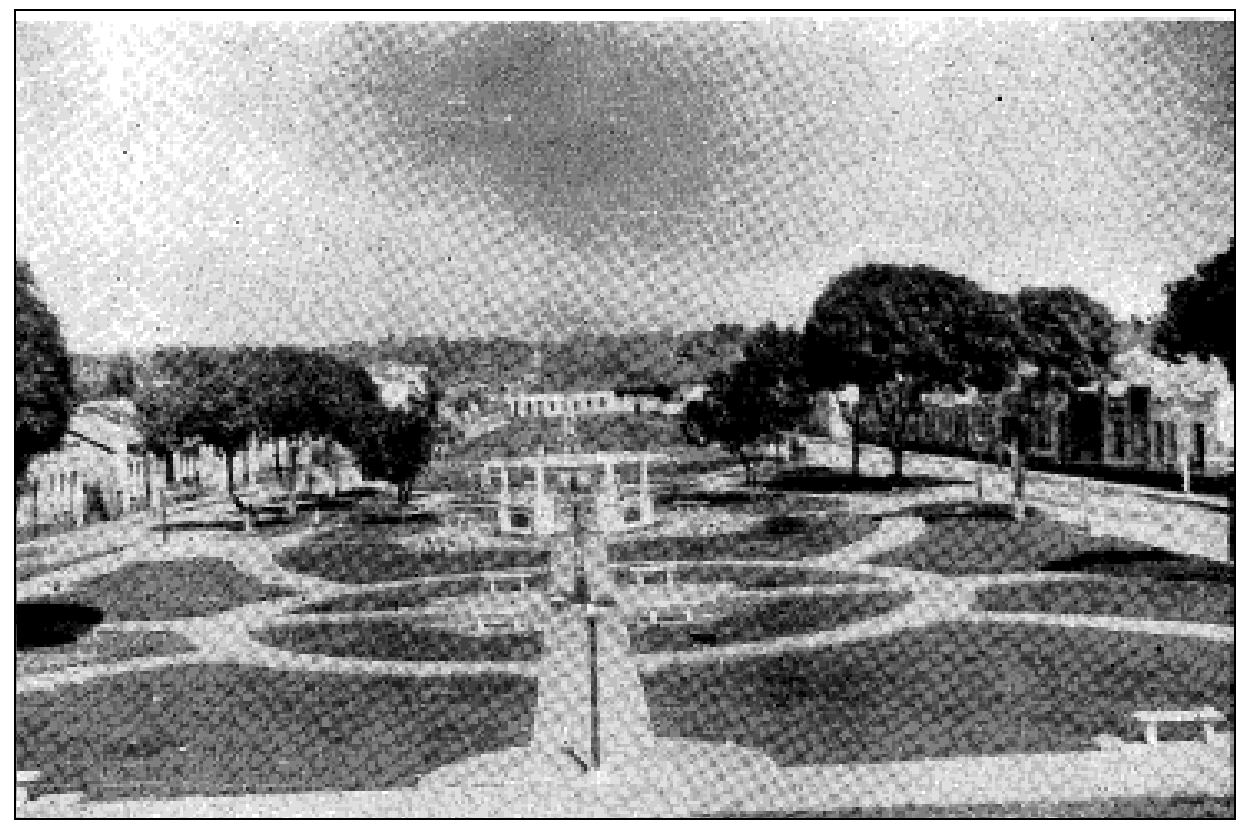

Foto 3: Praça Duque de Caxias

Fonte: Dias, 1958.

Comentário: a praça marca um importante momento da expansão urbana de Marabá, estando localizada em área mais alta, passou a concentrar os prédios públicos da cidade, que saíram da área alagadiça da extremidade da confluência do Tocantins com o Itacaiúnas.

No segundo período de crescimento da cidade apontado por Dias (1958), de 1947 a 1954, a área urbana chegou a atingir a zona rural a partir da fazenda Santa Rosa, a partir da constituição de um novo bairro que conservou o antigo nome da fazenda, trata-se atualmente de uma área do subúrbio de Marabá.

Outra área ocupada a partir da expansão urbana até 1954 é a que vai no sentido sudeste do rio Tocantins. Área que se constituiu, tal com àquela da fazenda Santa Rosa, por

\footnotetext{
${ }^{7}$ A Avenida Antônio Maia era até então a principal via da cidade de Marabá.
} 
populações que vinham para a atividade da castanha e que ali se estabeleciam pela maior possibilidade de conseguirem emprego no período da entressafra em outras atividades, como a do garimpo, por exemplo, as chamadas "atividades de verão". A ocupação se dava também, pelo fato de que nessa área os terrenos eram os menos valorizados da cidade, onde se tinha maiores dificuldades de abastecimento de água e de alimentos, em virtude da distância do rio e do centro comercial da cidade (DIAS, 1958). (Figura 1) 


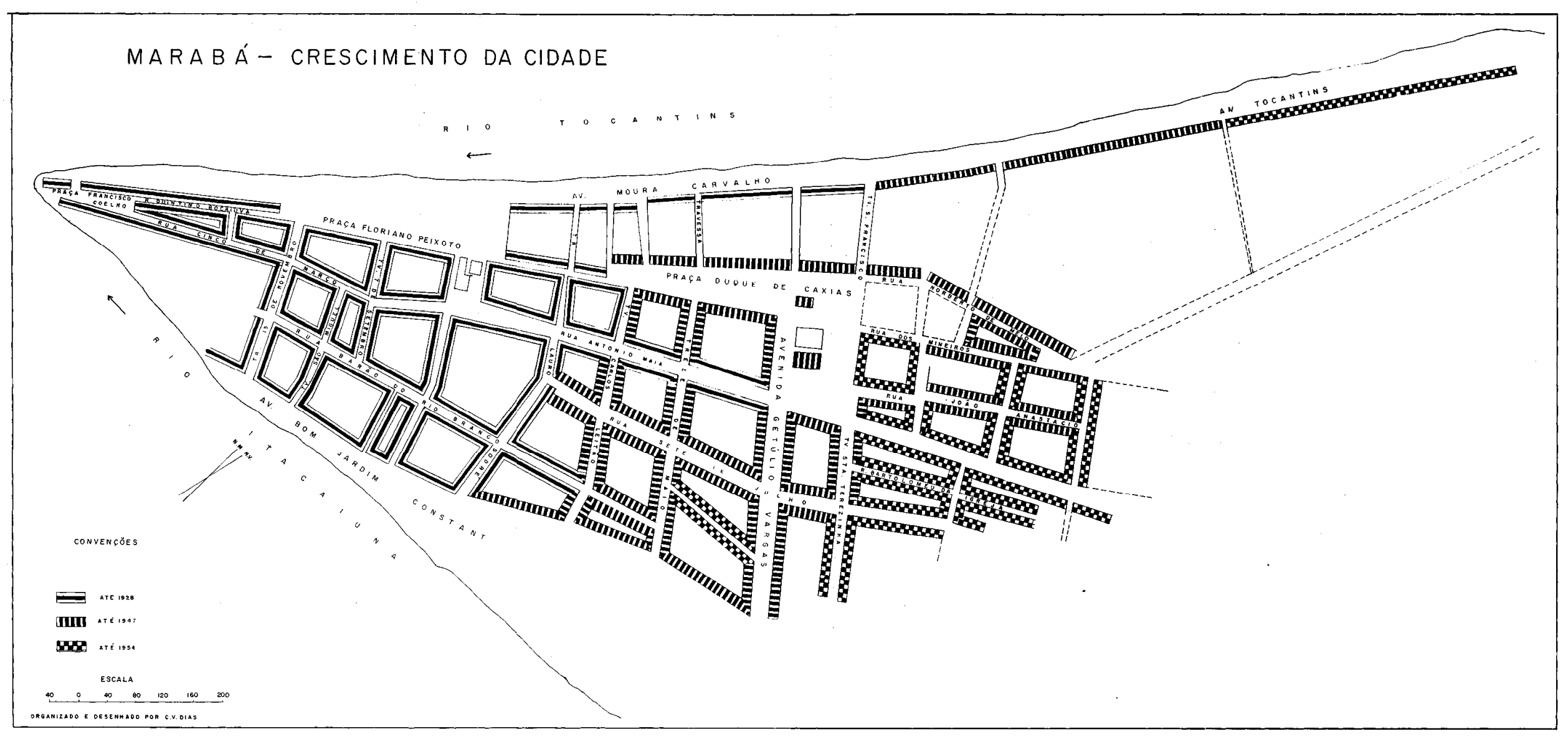

Figura 1: crescimento da cidade de Marabá Fonte: Dias, 1958.

Comentário: a figura 1 ilustra o crescimento da cidade de Marabá, caracterizando a importância da atividade da castanha como fomentadora do dinamismo econômico do município, que contribuiu fortemente para as mudanças no caráter urbano de Marabá. 
Paralelamente à exploração da castanha, em Marabá desenvolvia-se ainda a atividade mineradora associada à exploração de diamantes e do cristal de rocha, que de acordo com Dias (1958), começou a ser explorado durante a segunda guerra mundial, e foi exatamente essa atividade que ajudou a cidade a se recuperar da crise econômica desencadeada pela queda do preço da castanha no mercado internacional.

Velho (1972) identifica nesse momento o que ele denomina de uma "frente mineradora norte-goiana", que se conforma a partir da decadência das minas no Centro-Sul, ainda no período colonial, o que contribui para o aumento do interesse pelo Norte e pela busca de recursos minerais, agora em escala mais reduzida. Essa busca por minérios, aproximou essa frente de Marabá, por onde, a partir do final da década de 1930, surge um interesse maior pela exploração de diamantes. As atividades de exploração da castanha e a busca por diamantes eram concomitantes, tendo em vista que a segunda era desenvolvida apenas no "verão", quando as águas dos rios baixavam. Isso serviu ainda, como um importante fator para a fixação de mão-de-obra na região.

Além da exploração de diamantes, segundo Velho (1972), no período da II guerra mundial, surge o interesse por outra atividade mineradora, a do cristal de rocha. Nesse momento a exploração do cristal torna-se relevante, já que os mercados consumidores da castanha reduziram-se até 1944. A exploração era realizada, ora em terra "livre", ora através também, do sistema de "patrão", pela necessidade do aviamento.

As atividades mineradoras diminuíram ainda mais o interesse pelo desenvolvimento da agropecuária, pela necessidade do abastecimento das "corrutelas", o que permitiu a alguns indivíduos certa acumulação nesse setor. Com o final da Guerra, a atividade mineradora, em especial a do diamante, permanece, ainda que com lento declínio. Até a primeira metade da década de 1950, têm ainda grande importância enquanto uma atividade complementar à da extração vegetal (VELHO, 1972).

Dias (1958) aponta ainda que:

Até 1940, à proporção que diminuía a safra da castanha, a ausência de trabalho forçava os emigrantes a regressarem parceladamente às regiões de onde haviam partido. Marabá atravessava vida pacata, contrastando com os dias buliçosos da safra. A descoberta do diamante e a exploração do cristal de rocha no Tocantins trouxeram uma nova função urbana: o abastecimento dos garimpos. Marabá constituiu-se em ponto obrigatório de parada das embarcações, devido à praça comercial que possui. A cidade oferecia uma série de vantagens, e assim de regresso dos garimpos os indivíduos fixam residência em Marabá. (DIAS, 1958, p.395) 
A área urbana de Marabá até os anos 1960 estava concentrada na margem do rio Tocantins, de um lado e de outro, em virtude de estarem ali alocadas as atividades de comércio e dos serviços, ainda que precários à época, mas que eram de suma importância, para o abastecimento das populações que ali se estabeleceram, bem como para os trabalhadores dos castanhais, que a tinham como base para a comercialização de seus produtos. E nesse sentido, a atividade de exploração da castanha na região, contribuiu diretamente para a consolidação desse primeiro núcleo urbano de Marabá. (mapa 1) 


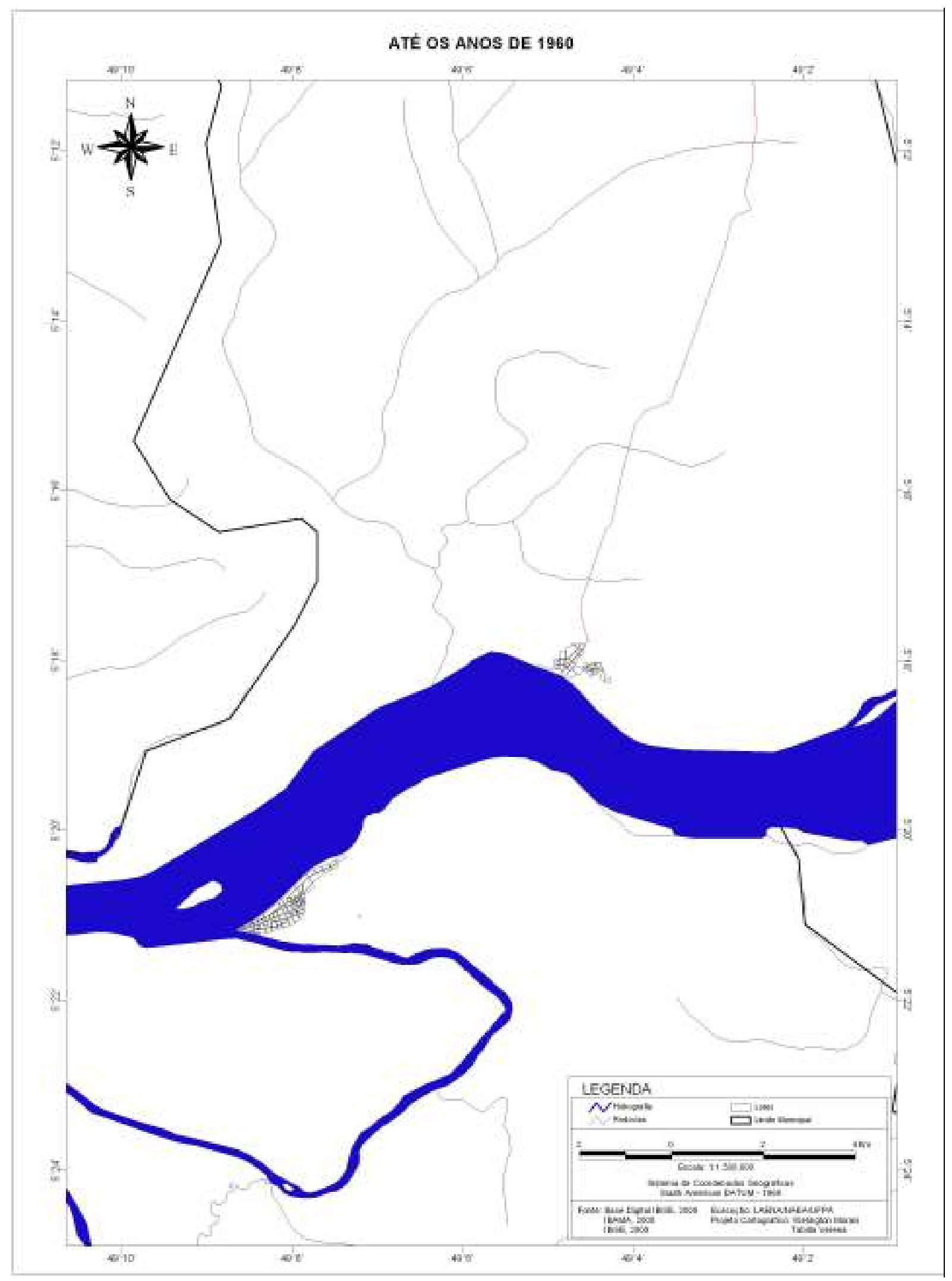

Mapa 1: Área urbana de Marabá até 1960 
Para finalizar esse momento do trabalho é importante afirmar que a cidade de Marabá teve seu surgimento e desenvolvimento associados à função comercial da indústria extrativa do caucho e posteriormente em virtude da exploração da castanha, e mais recentemente do cristal de rocha e diamante. Pelo papel que desempenha, junto ao sudeste do Pará, o oeste do Maranhão e o norte de Goiás, Marabá pode ser considerada de acordo com Dias (1958), como uma verdadeira capital regional.

\subsection{Marabá como base das políticas de desenvolvimento regional da Amazônia Oriental}

A partir de meados de 1960, a realidade de Marabá começa a passar por uma profunda transformação decorrente da integração da Amazônia à modernização capitalista, que modificou as relações existentes na região. Segundo nos indica Emmi (1999), Marabá nesse período, não é mais apenas uma terra de castanhais, como fora conhecida até os fins dos anos 1950, ainda que as análises devam considerar as áreas de castanhais, estas vão deixando de ser o centro dos interesses econômicos. Marabá, aos poucos, vai se integrando ao restante do Brasil pela via rodoviária, e para o município convergem novos interesses, especialmente do capital industrial e financeiro, cuja riqueza está relacionada à exploração mineral, e também agropecuária.

Ainda segundo essa autora, a nova concorrência estabelecida em torno da propriedade da terra, prefigurou o declínio do poder político das famílias oligárquicas de Marabá, pois com a política de integração nacional a terra deixou de ser monopólio dos comerciantes da castanha para servir, por um lado, de base às atividades produtivas das empresas capitalistas estatais, como é o caso da Companhia Vale do Rio Doce (CVRD), e das empresas capitalistas privadas, como é o caso do Banco Bamerindus, e por outro lado, ser apropriada para a construção da rodovia BR - 230 (Transamazônica) com o objetivo de promover a colonização agrícola, através do Instituto Nacional de Colonização e Reforma Agrária (INCRA), e servir

de suporte às ações empreendidas pelo Grupo Executivo de Terras do Araguaia-Tocantins (GETAT), ou ainda para ser tomada pelos garimpeiros, fiscalizados pelo Serviço Nacional de Investigação (SNI), como em Serra Pelada.

Esse novo período da formação socioespacial de Marabá e da Amazônia oriental, pode ser definido como de expansão da fronteira, entendida na acepção de Becker (1998). Para esta autora, a fronteira não deve ser entendida como sinônimo de terras devolutas, em que a apropriação econômica está franqueada a pioneiros ou camponeses, tratando-se de um espaço 
social e político, que pode ser definido "como um espaço não plenamente estruturado, potencialmente gerador de realidades novas" (BECKER, 1998, p. 11). A fronteira, nesse sentido, funciona para a nação como símbolo e fato político de primeira ordem, uma vez que é o espaço de projeção para o futuro. Para o capital, essa fronteira, tem um valor de espaço em que se pode implementar velozmente novas estruturas, além de servir como reserva energética. Essa potencialidade econômica e política da fronteira foi que a tornou uma região estratégica para o Estado, que se esforça para promover sua rápida estruturação e controle (BECKER, 1998).

A partir dos anos 1970, é o Estado brasileiro que assume a responsabilidade por um novo e ordenado projeto de "devassamento amazônico", tal projeto está vinculado a um novo padrão de inserção do Brasil na ordem planetária, que por sua vez é moldada por um vetor científico-tecnológico moderno. Nesse sentido, a ocupação da Amazônia vai se tornando uma prioridade máxima com os militares, que fundamentados na doutrina de segurança nacional, promovem a implantação de um projeto de modernização nacional, neste projeto a Amazônia assume uma posição central face às prioridades econômicas e geopolíticas. Internamente é vista como um mecanismo para solucionar as tensões sociais do nordeste e para ajudar a dar continuidade ao crescimento do centro dinâmico do país, por meio da possibilidade de se ter um novo espaço para investimentos, para recursos e para mercados. No plano externo, devese destacar, a vulnerabilidade da imensa e isolada região quanto à organização de focos revolucionários, o dinamismo interno dos países vizinhos que, por mais que sejam menos industrializados, têm projetos de fazer investimentos e de incentivar o movimento da população para suas amazônias. Somem-se a isso, as preocupações do Brasil em assegurar a exploração dos recursos naturais (BECKER, 1998).

Segundo Becker (1998), para colocar em prática o projeto acima indicado, e promover a ocupação da Amazônia, o governo federal adotou três estratégias principais: a primeira delas refere-se à implantação de redes de integração espacial, tais como, a rede rodoviária que foi ampliada com a construção de grandes eixos transversais como a Transamazônica e a Perimetral Norte, mas também, intra-regionais, como Cuiabá-Santarém e Porto Velho Manaus; a rede de telecomunicações por satélite, que permitiu a difusão da televisão e do telefone; a rede urbana, que funcionava como sede das instituições do Estado e organizações privadas; e a rede hidroelétrica, que fornece energia para a nova fase industrial na região.

A segunda alude a superposição de territórios federais sobre os estaduais, em que, o governo federal, foi se apoderando de terras estaduais, por meio de decretos que criaram territórios sob sua jurisdição absoluta e por direito de propriedade. O primeiro grande 
território, segundo a autora, foi o da Amazônia Legal, e se sobrepôs à região Norte, aumentando assim os limites da atuação governamental. Em seguida (1970 - 1971), o governo determinou uma faixa de $100 \mathrm{~km}$ de cada lado de todas as estradas federais, que pertenciam à esfera pública, que usou como justificativa para sua apropriação a distribuição de terras para camponeses em projetos de colonização. Mais adiante (depois de 1974), o Estado vai implantar uma estratégia seletiva, o Polamazônia, que criou 15 pólos de desenvolvimento que recebiam investimentos voltados para as atividades de produção especificas de cada pólo especializado, pois, como o governo considerou a colonização lenta e custosa, passou então a estimular imigrantes com melhor poder aquisitivo, o que resultou na expansão de empresas agropecuárias e de mineração. Por fim, no final dos anos 1970, com a crise econômica e a ampliação dos conflitos, o governo mais uma vez, muda sua estratégia de atuação, buscando reduzir as despesas públicas, aumentar rapidamente as exportações e desenvolver tecnologia, de modo a concentrar recursos em poucas e grandes áreas selecionadas, bem como ampliar a ação militar, como forma de solucionar os conflitos. Nessa direção é que se inserem o Programa Grande Carajás (PGC) e o Projeto Calha Norte (PCN), os novos territórios produzidos.

A terceira estratégia do governo federal, diz respeito aos subsídios voltados ao fluxo de capital e indutores dos fluxos migratórios para a região. Trata-se da criação de recursos fiscais e creditícios subsidiados pelo Estado, por meio de bancos oficiais, especialmente o Banco da Amazônia (BASA), ao capital, principalmente do Sudeste. Ao mesmo tempo, foram induzidas migrações por meio de diferentes mecanismos, com o objetivo de promover o povoamento e a formação de mão-de-obra (BECKER, 1998).

Segundo indica Machado (1999), essa intervenção estatal no povoamento da região e com a conseqüente valorização das terras amazônicas, foi fundamental no período de 1966 a 1985. Destaca por um lado, a subordinação dos projetos de colonização regional ao projeto maior, de modernização institucional e econômica, por outro lado destaca o uso de redes técnicas modernas, com o intuito de estimular e viabilizar a mobilização de capitais e de migrantes para essas novas frentes de povoamento. O mais importante, porém, não é destacar que na experiência amazônica a aglomeração urbana serviu de base logística para a ocupação do território - o que já era comum desde o processo pioneiro de ocupação - também, não é o fato de o Estado intervir diretamente na criação de cidades. O que a experiência amazônica oferece de singular, segundo a autora, é a gênese quase instantânea nesse imenso território, de um sistema urbano que é, simultaneamente, a condição e o produto do sistema de povoamento da região. Devendo-se destacar que esse sistema urbano é produto de duas ordens, uma ordem 
intencional, direcionada pela ação governamental, das empresas e das instituições, e uma ordem espontânea (auto-organizativa) produzida pelo mercado (de terras, de trabalho, de bens, de serviços etc.), pela ação das estruturas sociais coletivas e pelos indivíduos.

Antes de entrar na discussão da formação socioespacial de Marabá nesse período, resta ainda falar da fronteira urbana, ou da urbanização como estratégia de ocupação territorial. Nessa direção, Becker (1998) afirma que:

Uma fronteira urbana é a base logística para o projeto de rápida ocupação da região, acompanhando e mesmo se antecipando à expansão de várias frentes. Trata-se de uma feição original da fronteira contemporânea. A urbanização não é aí uma conseqüência da expansão agrícola: a fronteira já nasce urbana, tem um ritmo de urbanização mais rápido que o resto do Brasil. E esta feição está intimamente associada à migração (BECKER, 1998, p. 44).

Ainda segundo essa autora, a importância da urbanização como estratégia de ocupação do território, está relacionada a três papéis fundamentais exercidos pelos núcleos urbanos: o núcleo urbano como um poderoso fator de atração de migrantes, como base da organização do mercado de trabalho e como lócus da ação político - ideológica do Estado.

Por mais que Machado (1999) não considere que a aglomeração urbana como base logística da ocupação territorial, seja uma novidade e uma singularidade histórica na Amazônia, não podemos deixar de ressaltar a importância desse processo para o sudeste paraense e principalmente para Marabá, que esteve no centro das políticas de desenvolvimento regional direcionadas para a Amazônia oriental.

Com a abertura da rodovia Transamazônica e o projeto de colonização dirigida implementado pelo governo federal no início da década de 1970, bem como as medidas de segurança nacional e os incentivos aos grandes empreendimentos agropecuários e minerais, vão impactar diretamente a dinâmica de Marabá e do sudeste paraense (TOURINHO, 1991).

Nesse período, Marabá vai ser declarada como área de segurança nacional e território de atuação direta do governo federal. Ela passou a servir como base para o exército brasileiro na luta contra a guerrilha do Araguaia, o que exigiu a ampliação de seu aeroporto e a instalação de destacamentos militares, como o Batalhão de Infantaria de Selva (BIS), elevado, repentinamente, à sede da Brigada de Infantaria de Selva, cuja instalação inicial estava prevista para a cidade de Santarém, no médio Amazonas (TOURINHO, 1991; YOSHIOKA, 1986).

Para Emmi (1999), essa passagem do município para área de segurança nacional, acaba acelerando ainda mais a perda de influência da oligarquia na política local. Os prefeitos 
que foram nomeados nessa época estavam comprometidos com o regime autoritário e desvinculados dos grupos locais, pois os interventores escolhidos não pertenciam a esses grupos, o que acabou contribuindo, em muitos casos, para a desapropriação de terras das famílias oligárquicas. Deve-se ressaltar, contudo, que essa oligarquia tem tentado se rearticular, com o intuito tanto de defender seu domínio fundiário, quanto do poder político que vem perdendo, desde que o capital mercantil, que era sua base de sustentação, cedeu lugar ao capital financeiro e industrial com seus representantes.

É importante destacar que as transformações econômicas ocorridas na região, que fizeram com que novos sujeitos sociais (empresários de diferentes setores, fazendeiros individuais e migrantes) fossem nela introduzidos, não significou o fim dos conflitos fundiários. À população tradicional que era composta de antigos trabalhadores dos castanhais, de ex-coletores independentes e de pequenos posseiros desterritorializados, vieram se somar grande número de migrantes sem-terra e de colonos atraídos pelo projeto de colonização agrícola da Transamazônica. Esse processo de ocupação tem sido, desde o início, violentamente marcado por conflitos sociais, que se expressam em conflitos espaciais/territoriais (COELHO, 2005). Emmi (1999) chega a afirmar que esses conflitos opõem grupos de trabalhadores rurais recém chegados a área, ou moradores antigos e grupos indígenas aos representantes da oligarquia da castanha e aos componentes da empresa capitalista que se expande na área, principalmente pecuaristas do centro-sul e grupos ligados ao capital financeiro.

No que se refere à política de colonização agrícola desenvolvida na rodovia Transamazônica pelo INCRA, principalmente entre 1970 e 1974, em áreas selecionadas de Altamira e Marabá, pode-se afirmar que seguiu o modelo do "urbanismo rural" 8 , que colocava no topo da hierarquia urbana as chamadas rurópolis, cidades de até vinte mil habitantes, localizadas a cada $200 \mathrm{~km}$, para servir como centros administrativos e comerciais da região; seguida pelas agrópolis, uma camada média de centros administrativos intermediários, localizadas num intervalo de $100 \mathrm{~km}$, que polarizavam em média vinte agrovilas, contavam com uma cooperativa, um posto de assistência social e de saúde, um posto de assistência técnica e serviços urbanos de infraestrutura; e pelas agrovilas, compostas de quarenta e oito (48) a sessenta e quatro (64) famílias, cada uma, localizando-se a cada $10 \mathrm{~km}$ ao longo da

\footnotetext{
${ }^{8}$ Trata-se do modelo de urbanismo rural do Instituto Nacional de Colonização e Reforma Agrária (INCRA) e que articula um sistema de núcleos urbanos configurados em localidades centrais hierarquizadas, aproveitando a estrutura urbana pré-existente para a configuração desse sistema de cidades, que por sua vez é baseado em uma estrutura social complexa: colonos, funcionários, comerciantes (bens, terras, força de trabalho), extrativistas, antigos moradores, burocracia, fazendeiro, migrantes etc.
} 
rodovia, possuíam em geral, uma escola primária, um posto de saúde e um pequeno comércio local. No seu entorno, a uma distância de $500 \mathrm{~m}$ a $5 \mathrm{~km}$ estavam localizados os lotes rurais, que em geral possuíam 100 há (VICENTINI, 2004).

Em Marabá foi implantado experiências de assentamento de colonos e de instalação de agrópolis e agrovilas, em que a sede municipal foi selecionada como núcleo de apoio ao Plano Integrado de Colonização dirigida (PIC), do INCRA. O núcleo pioneiro ou Velha Marabá, passou a exercer a função de rurópolis e a área localizada próximo ao aeroporto passou a funcionar como agrópolis, onde estava a sede do INCRA e uma vila de moradias para os funcionários desse órgão. Esta área, depois vai ser incorporada à cidade por meio do núcleo denominado de Cidade Nova, que já era ocupada desde 1947, por barracas construídas próximas ao que era à época o campo de aviação, no chamado "bairro Amapá", que abrigava 1.450 pessoas, que foram atingidas pelas enchentes (DIAS, 1958).

De acordo com Becker (1990), o núcleo Cidade Nova deve ser visto como lócus da ocupação espontânea da força de trabalho móvel que sustenta os grandes projetos, os garimpos e as fazendas, e dos colonos em trânsito, de modo que a cidade cresce horizontalmente, a cada dia, ao longo da Transamazônica, onde tem-se observado um comércio mais dinâmico e o início de uma diferenciação interna em meio ao amontoado de casas de madeira. A respeito dessa área, Tourinho (1991) faz a seguinte afirmação:

Do outro lado do rio Itacaiúnas, a ampliação do aeroporto, a instalação de
uma vila para abrigar os funcionários do INCRA, a abertura de um
loteamento (Vila Transamazônica), bem como, a intensificação da ocupação
do bairro do Amapá deram um ar mais urbano à antiga aglomeração
populacional, que desde então passou a ser conhecida pela denominação de
COMPLEXO INTEGRADO CIDADE NOVA. Essa área, embora não
dispusesse de serviço de abastecimento de água, energia elétrica,
pavimentação asfáltica nas vias etc.; atraía grandes contingentes de
imigrantes que não conseguiam pagar pela valorização fundiária das áreas
mais bem dotadas de serviços e equipamentos urbanos do Núcleo Pioneiro,
mas que não aceitavam residir nas menos onerosas áreas alagadas ou
facilmente alagáveis daquele núcleo (TOURINHO, 1991, p. 271)

No período em discussão, é importante destacar a implantação do núcleo de Nova Marabá, que seria o principal centro de apoio às políticas que vinham sendo desenvolvidas na região. Esse núcleo estava destinado a receber fluxo migratório, devendo-se estruturar física e administrativamente para abastecer as populações com sua produção agropecuária, e a prestar serviços de apoio à microrregião. Segundo indica YOSHIOKA (1986), visando implantar o Plano de Integração Nacional (PIN), o Serviço Federal de Habitação e Urbanismo (SERFHAU), elaborou o plano de desenvolvimento para o Norte e o Nordeste, sendo que 
cada município ficava obrigado a elaborar Plano de Desenvolvimento Municipal. Neste contexto, Marabá recebeu entre os meses de janeiro e fevereiro de 1970, uma equipe interdisciplinar composta por estudantes de economia, sociologia e engenharia resultante do convênio entre SERFHAU e o grupo de trabalho do Projeto Rondon. O relatório preliminar, de março de 1970, sugeriu como hipótese que a região seria atingida pelas descobertas e pelo potencial do minério de ferro de Carajás. Além disso, estabeleceu assistência técnica, crédito rural e títulos de posse de terra aos agricultores, de maneira a garantir a sua fixação no campo e criando uma motivação para a produção.

Ainda sobre esse plano, Almeida (2002) afirma que não se pode perder de vista que o mesmo decorre do Projeto Carajás, que o município de Marabá era parte integrante, pois concentrava a mão-de-obra necessária a esse empreendimento. Sob o discurso de produzir espaço de habitação para os atingidos pelas enchentes, a Nova Marabá tinha como intuito principal receber a corrente migratória necessária à exploração mineral, com destaque para o ouro do garimpo de Serra Pelada.

O plano de desenvolvimento urbano de Marabá estabelecia que a cidade deveria ter em torno de 50.000 habitantes, num modelo que buscava conciliar o projeto, a ecologia, e as particularidades regionais, considerando ainda, o nível social das populações, como afirmou o superintendente do SERFHAU apud YOSHIOKA (1986), a implantação desse projeto permitiria um modelo experimental controlado, de cidades de tipo amazônico, obedecendo às características regionais, a exemplo de modelos já desenvolvidos em outros países.

De acordo com Almeida (2002), o plano desenvolvido pelo SERFHAU, tinha um caráter amplo, pois estabelecia parâmetros substanciais para todas as necessidades básicas de um núcleo urbano em processo de formação, tais como, sistema viário, sistema de esgoto, água potável, sistema de coleta de lixos, etapas para locação habitacional etc. Como forma de obter o apoio da população local para o projeto, foi realizada uma intensa propaganda com a intenção de que a Nova Marabá pudesse ser vista como único meio de desenvolvimento futuro para o município.

A demora no desenvolvimento das ações referentes à construção da Nova Marabá residiu em fatores que vão além da simples discordância com a solução habitacional e as etapas de implantação apresentadas em parecer técnico por funcionários da Superintendência de Desenvolvimento da Amazônia (SUDAM), sobre o plano de desenvolvimento urbano. Na verdade, os reais fatores são, de um lado, a crise que atingiu o País depois de 1973, com o choque do petróleo, e por outro lado, a transição do governo Médici para o governo Geisel, que provocou uma mudança na tecnocracia do Estado e nas ações do governo para a região, 
inclusive privilegiando a colonização privada e extinguindo a SERFHAU, órgão que estava acompanhando o planejamento urbano marabaense (TOURINHO, 1991; YOSHIOKA, 1986).

Nesse momento, em que todos os fatores pareciam indicar que a idéia de implantação de uma nova cidade em Marabá estaria fadada ao discurso oficial, o núcleo Pioneiro de Marabá foi atingido por uma grande enchente, que inundou cerca de $80 \%$ dos prédios existentes na Velha Marabá, o que levou a uma forte pressão local junto à SUDAM, para dar continuidade ao projeto de construção da nova cidade e/ou resolver os problemas de moradia dos ocupantes das áreas inundadas e dos imigrantes que chegavam à cidade (TOURINHO, 1991).

No lugar do plano de desenvolvimento urbano municipal, veio se instalar, sob a direção da SUDAM, o Plano de Expansão Urbana de Marabá. A primeira atitude da SUDAM ao assumir a responsabilidade do planejamento foi rechaçar as propostas de estruturação e de desenho urbano presentes no plano da SERFHAU, contratando uma empresa de consultoria sediada no Rio de Janeiro. Segundo YOSHIOKA (1986),

O plano urbanístico (PDUMAR) anteriormente contratado pelo SERFHAU mostrou-se inadequado, por estarem suas características principais desassociadas dos princípios do sistema ecológico regional e das condições sócio - econômicas da população. A rigor, o plano anterior estaria superado pelos atuais prognósticos de incremento populacional, uma vez que se destinava a uma população de apenas 50.000 habitantes, segundo uma estrutura urbana rígida, dificilmente capaz de atender a uma demanda populacional maior, ou a um crescimento orgânico sistematizado. Razão pela qual foi ele reestruturado de acordo com os novos princípios e diretrizes preconizados neste documento. (SUDAM apud YOSHIOKA (1986, p. 103104)

Por fim, podemos afirmar que o núcleo de Nova Marabá, fruto da ação do Estado, planejada pela SUDAM, em forma de folhas de castanheira ${ }^{9}$ (figura 2), onde a área urbana sucede a áreas verdes para onde se transferiram as sedes do governo e das atividades estatais, os bancos. Somente no início da década de 1980 vem sendo povoada, pela venda dos lotes e por "invasões" (BECKER, 1990). O desenho urbano, considerado "excêntrico" nunca foi de fato assimilado pela população, o que leva a prefeitura a, constantemente, inaugurar pontes

\footnotetext{
${ }^{9}$ De acordo com Almeida (2002), a folha seria uma comunidade básica, que disporia de um núcleo de comércio e serviços, composto de mercearias, padarias, bares, açougues, farmácias, posto de saúde, escolas, cabeleireiros, telefones públicos, e alguns pequenos comércios. Com a junção de duas ou mais folhas, o núcleo de comércio e serviços ganharia maiores proporções, com supermercados, farmácias, laboratórios, postos de gasolina, pequenos clubes, cinemas, corpo de bombeiro, delegacia e correio. O centro localizado no entroncamento da Transamazônica teria função principal de apoio à cidade e à região, dispondo de grandes empresas, órgãos governamentais etc.
} 
interligando as folhas, como são denominadas as áreas internas ao desenho urbano (VICENTINI, 2004).

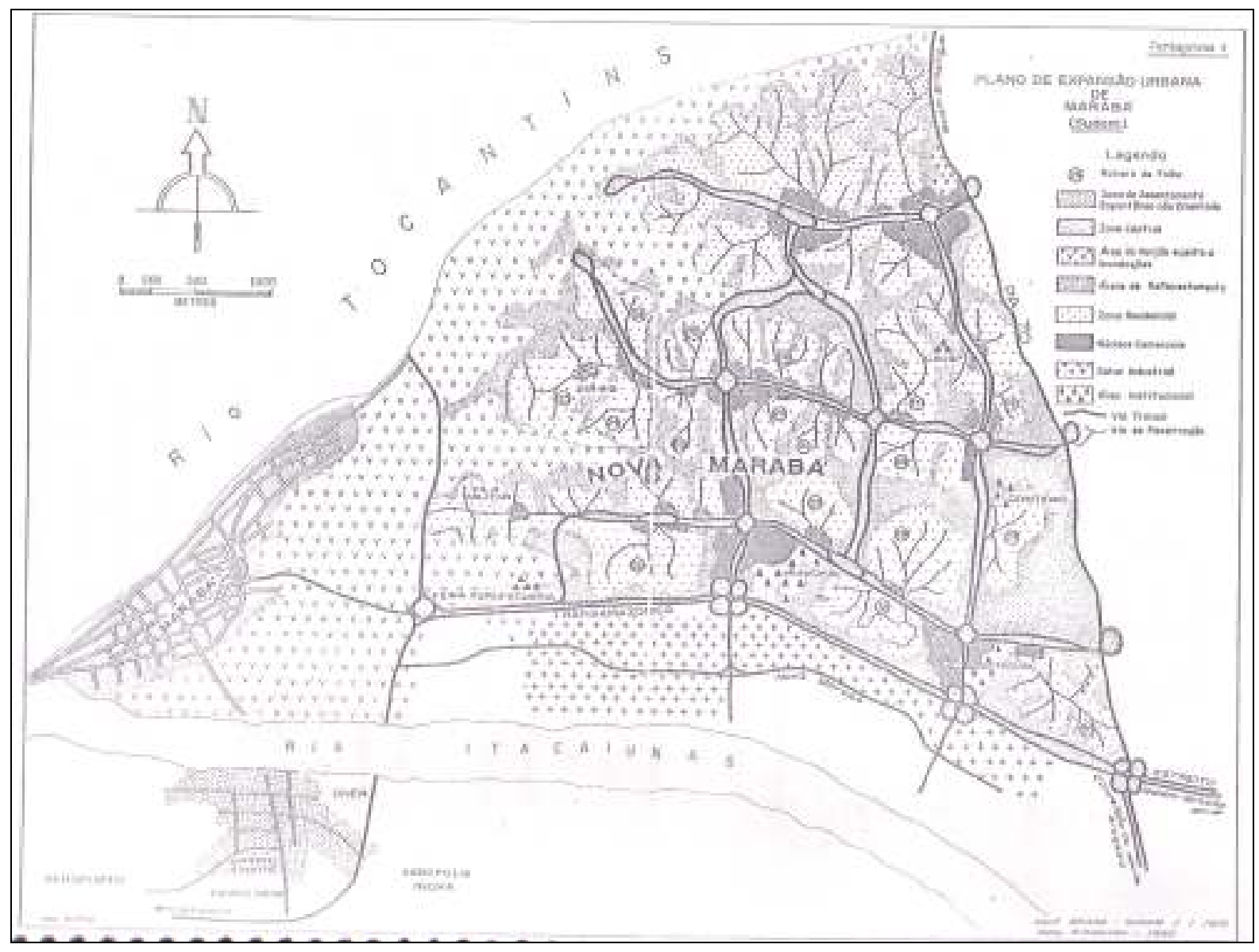

Figura 2: Planta do Projeto da SUDAM da Nova Marabá Fonte: YOSHIOKA, 1986. 
Conforme nos informa Almeida (2002), a implantação da Nova Marabá ocorreu numa área de 1.650 hectares, desapropriada pela SUDAM, onde foram indenizadas as benfeitorias da então fazenda Santa Rosa. Depois disso a SUDAM iniciou a implantação física do plano, por meio da abertura do sistema viário, que ficou a cargo do Departamento de Estradas de Rodagem do Pará (DER-PA).

Após essa fase de abertura do sistema viário, segundo Yoshioka (1986), teve início, a partir de 1976, a motivação junto aos moradores da área alagadiça da Marabá Pioneira (o chamado varjão), para se mudarem para a Nova Marabá. Nesse momento, segundo Almeida (2002), os problemas começam a ser evidenciados, pois os moradores deveriam comprar seus lotes financiados por meio de contrato de concessão de uso firmado com a SUDAM, porém, depois de formalizado o processo, o adquirinte era obrigado a demolir sua antiga residência na Marabá Pioneira. De acordo com esse autor, para o morador da Marabá Pioneira, a mudança constitui-se no distanciamento dos rios, da inexistência de água encanada e energia elétrica, e ainda era necessária uma caminhada de 3 a 4 quilômetros para que se pudesse chegar ao emprego e ter acesso aos serviços (escola, abastecimento etc.) ou qualquer tipo de lazer existente apenas na Velha Marabá.

Ainda segundo Yoshioka (1986), apesar da ocupação da Nova Marabá ter se iniciado nos primeiros meses de 1976, ao final desse ano poucas famílias efetivamente morando na área. Foi somente com a ameaça de cheias no início de 1977, a cheia de 1978, 1979 e 1980 que o escritório da SUDAM passou a ser intensamente procurado por pessoas atingidas pelas enchentes, inclusive algumas que haviam recebido lote anteriormente e que não chegaram a ocupá-lo. A pressão sobre os técnicos da SUDAM para que liberassem os lotes era intensa, vindas de toda parte, principalmente dos políticos, mas a realidade é que não existiam lotes preparados ou demarcados para serem entregues na quantidade demandada, pois o desenho dessas folhas era realizado no Rio de Janeiro, enviados a Belém e de lá para Marabá. 


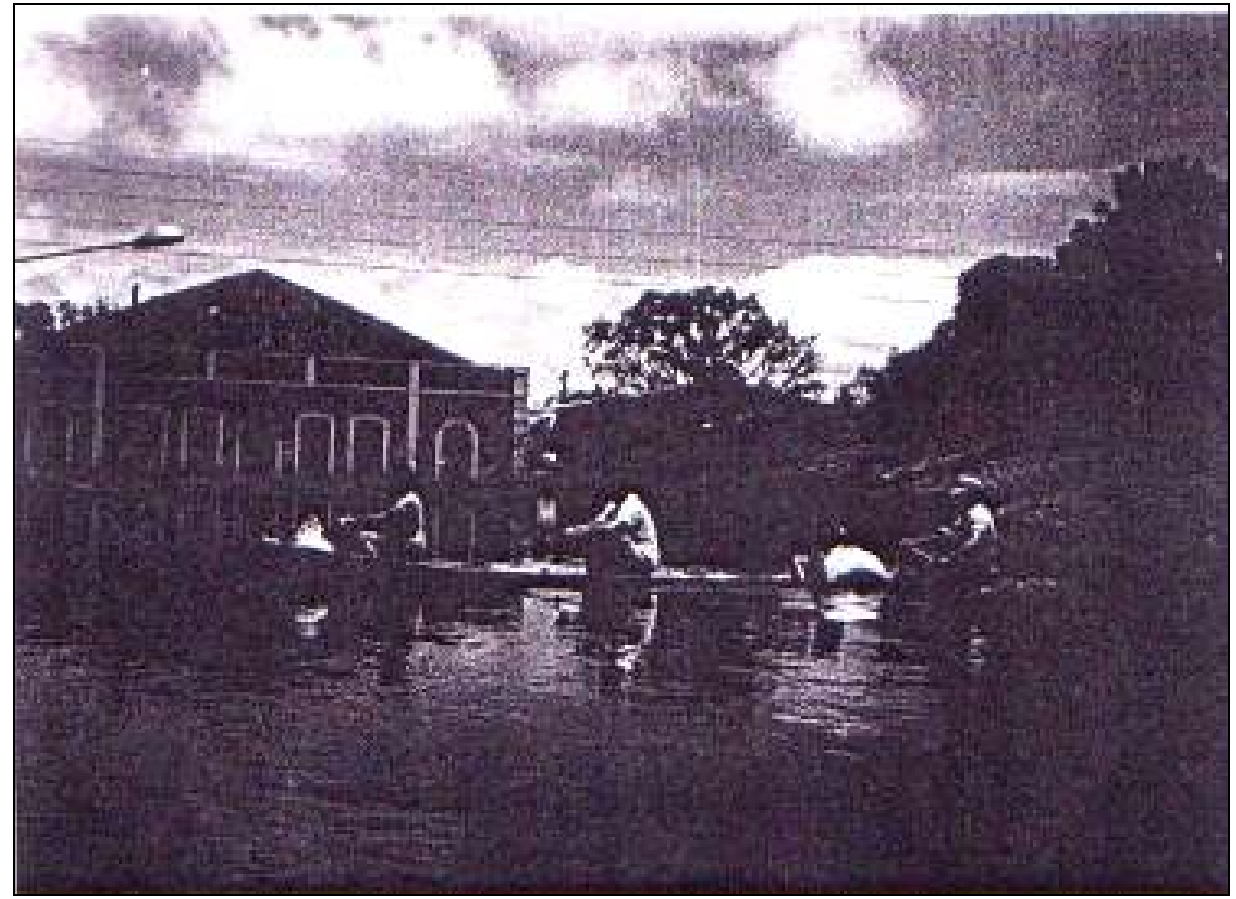

Foto 4 : Enchente na Marabá Pioneira em 1980

Fonte: YOSHIOKA, 1986.

Comentário: as enchentes em Marabá atingiam o núcleo pioneiro mesmo após a melhoria de sua infraestrutura urbana, o que ainda hoje se verifica na cidade, no período chuvoso, quando o rio Tocantins chega a níveis bastante elevados.

Em síntese, como diz Tourinho (1991), quando a SUDAM transferiu para a prefeitura de Marabá a responsabilidade para dar continuidade da implantação da Nova Marabá, no início da década de 1980, a Velha Marabá continuava a apresentar problemas de ocupação de áreas alagadas e alagáveis, a Cidade Nova tinha seu crescimento estrangulado pela incidência de grandes latifúndios, e a Nova Marabá permanecia demandando grandes investimentos para viabilizar o modelo de ocupação fundado em baixas densidades e altos custos infraestruturais.

Ainda falando desse período em que a cidade de Marabá funcionou como base das políticas voltadas ao desenvolvimento regional, destacarmos a fase que se inicia em 1980, vista, na maioria das vezes, como o período em que a cidade ficou sob a égide do capital corporativo, principalmente, da CVRD.

De imediato, é preciso afirmar que três fatores foram fundamentais para intensificação da penetração de frentes econômicas e para as transformações operadas na estrutura produtiva e urbana da cidade de Marabá: o Projeto de Ferro Carajás e o Programa Grande Carajás; a implantação do pólo siderúrgico; e o ouro do garimpo de Serra Pelada (TOURINHO, 1991).

O Projeto de Ferro de Carajás, exclusivo da CVRD, é um sistema integrado que envolve mina, onde ocorre a extração do minério na Serra dos Carajás; ferrovia, denominada Estrada de Ferro Carajás, com 890 km; pelo porto de Itaqui, na ponta da Madeira em São 
Luís; e pelos vários núcleos urbanos e projetos industriais, voltados à mineração e exportação de ferro da província mineral de Carajás no sudeste paraense (COELHO, 1997; BECKER, 1998).

Para realização das obras de construção civil desse grande projeto de exploração de ferro, foi necessário atrair para região, empreiteiras e um grande número de trabalhadores, que encontraram na cidade de Marabá o suporte necessário para desenvolver suas atividades, uma vez que não conseguem ser absolvidos pelo Projeto Carajás que é altamente seletivo. Além desse aspecto, devemos destacar que a instalação da ferrovia promoveu, de um lado, a construção de uma ponte sobre o rio Tocantins, que fez a ligação direta do núcleo Nova Marabá com São Felix, e, de outro lado, a construção de um ponte sobre o rio Itacaiúnas, permitindo a integração viária do núcleo Cidade Nova com as demais da cidade (TOURINHO, 1991).

A implementação do pólo siderúrgico, segundo indica Monteiro (1997), é composto por plantas industriais cujos capitais são, em sua grande maioria, provenientes de grupos empresariais de outras regiões do país e que migraram para Amazônia, incentivados pelas facilidades oferecidas pelo Estado brasileiro, que colocava a sua disposição facilidades infraestruturais, creditícias e fiscais para a instalação de suas plantas industriais. Ainda com base nesse autor, podemos dizer que para desenvolver suas atividades essas indústrias de ferrogusa precisam se articular regionalmente para tanto o carvão vegetal - obtido de áreas de fazendas, de serrarias e de assentamentos - quanto do próprio ferro, proveniente da província de Carajás.

Como destacou Coelho (2005), dentro do PGC, os esforços realizados para ampliação dos linkages foram concentrados na industrialização do ferro de Carajás, por meio de estímulos a transferência de guserias do sudeste, principalmente, Minas Gerais, para o corredor da Estrada de Ferro. Como essas guserias, na avaliação da autora, apresentam pequena margem de lucro face aos baixos preços do produto no mercado, pode-se afirmar que ela não tem gerado efeitos capazes de multiplicar outras atividades, considerando, ainda, que provocam o desmatamento devido o uso do carvão vegetal em suas atividades.

Segundo Tourinho (1991), depois dos anos de 1980, depois da criação do PGC, várias empresas do setor sídero-metalúrgico se interessaram em instalar suas indústrias de transformação mineral nas áreas próximas da extração e do transporte de ferro. Como forma de incentivar a instalação desse tipo de empreendimento, o governo estadual, criou ainda nos anos 1980, o Distrito Industrial de Marabá. De acordo com Monteiro (1997) nessa década, várias siderúrgicas se instalaram no corredor da Estrada de Ferro Carajás, das quais cinco se 
encontram no Maranhão (Maranhão Gusa/MARGUSA, Companhia Siderúrgica Vale do Pindaré, Viena Siderúrgica, Gusa Nordeste S.A, Siderúrgica do Maranhão/SIMASA) e duas no Pará (Companhia Siderúrgica do Pará/COSIPAR e Siderúrgica Marabá/SIMARA).

O garimpo de Serra Pelada está localizado numa área entre a cidade de Marabá, no município de Curionópolis, e a Serra dos Carajás, numa área distante $88 \mathrm{~km}$ da sede municipal. O descobrimento do ouro e a política oficial de liberação das áreas para pesquisa mineral levou para região um explosivo fluxo migratório de cerca de 60 mil homens. De acordo com Becker (1998), com essa atitude o governo federal buscou agradar políticos locais e empresas agropecuárias interessadas em obter mão-de-obra fácil fora de suas fazendas, mas também desagradou a Docegeo, uma empresa subsidiária da CVRD, que possuía os direitos de pesquisa e lavra da Serra Pelada desde 1974.

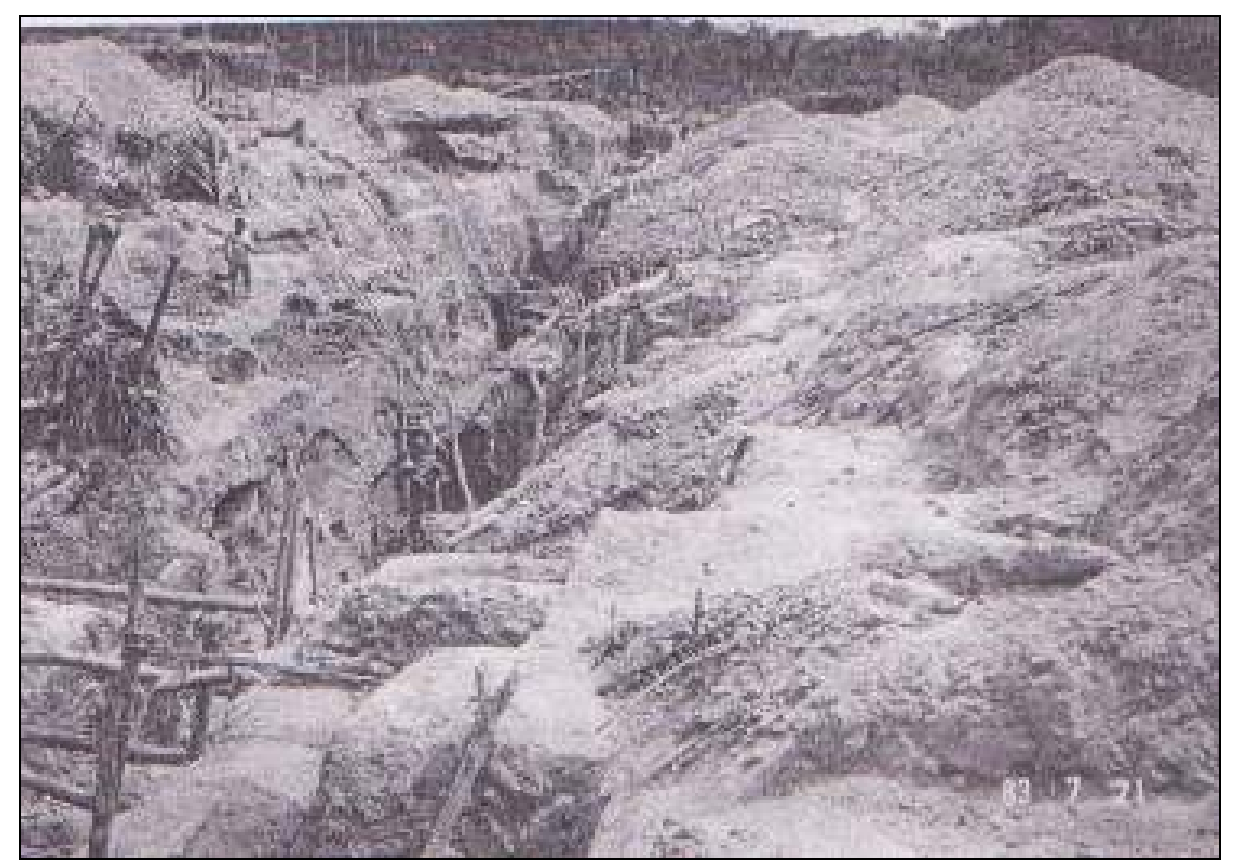

Foto 5: Garimpo nas proximidades de Serra Pelada

Fonte: YOSHIOKA, 1986.

Comentário: a atividade garimpeira na região foi responsável não apenas pela exploração do minério, mas também do trabalho humano, em que muitos daqueles que se direcionaram para essa área, acabaram morrendo em busca do sonho de enriquecimento, pelas péssimas condições de trabalho e sobrevivência.

Para Coelho (2005) Serra Pelada passou de um território fechado, onde a ordem interna era imposta pela Cooperativa (atualmente Cooperativa de Mineração dos Garimpos de Serra Pelada - COOMIGASP), pela Caixa Econômica Federal, pela Polícia Federal e pela Receita Federal, no período de 1980 a 1984, enquanto o ouro ainda existia para uma desordem com o esgotamento das áreas de fácil extração. Para essa autora, a experiência de Serra Pelada 
é ilustrativa do processo de exploração das "ilhas de sintropia" - o estado de um sistema de elevada ordem -, no sudeste paraense, e de suas conseqüências sociais, através da geração da entropia - grau de transformação ou de evolução de sistema físico.

Tourinho (1991) considera que os incentivos do Estado à exploração de Serra Pelada era, em verdade, uma válvula de escape, uma vez que, de um lado, era uma estratégia para estimular a vinda de grandes contingentes de trabalhadores desempregados existentes no país, e, de outro lado, era uma forma de obter divisas num contexto de crise.

Dois dados são importantes para se verificar os impactos do garimpo sobre a cidade de Marabá. O primeiro deles é a proibição do ingresso de mulheres nas áreas de garimpo, o que fez com que a maior parte das famílias de garimpeiros se instalasse na cidade de Marabá, o que contribuiu para ampliação da grande demanda por lotes, serviços e equipamentos urbanos dessa cidade. O segundo refere-se ao fato de que com o fim da lavra manual e a proibição da extração, parte do contingente populacional que trabalhava no garimpo foi se estabelecer na cidade de Marabá, esperando encontrar na mesma um emprego (TOURINHO, 1991).

Para terminar, é necessário destaca ainda que Marabá funcionou também, nessa época, como palco para diferentes conflitos fundiários, principalmente, nas áreas de antigos castanhais que passaram a ser ocupados por trabalhadores sem-terra, especialmente, os imigrantes. Conforme indicam Emmi e Acevedo Marin,

O ano de 1985 foi marcado por chacinas em áreas de castanhais, isto é, violentos conflitos que ocasionaram muitas mortes. É o caso das lutas, com 44 mortos, nos castanhais Pau Ferrado, Surubim, Ubá, Fortaleza e princesa, todos de famílias oligárquicas (1996, p. 62).

É importante registrar que essa luta dos trabalhadores, mobilizados e organizados a partir de Marabá, não tem sido em vão, pois os mesmos têm conseguido várias conquistas, como, por exemplo, a desapropriação de 29 áreas de castanhais somente em Marabá, o equivalente a 66.865 há, onde foram assentadas 1.300 famílias. Mas de outro lado, também, deve ser ressaltado o fato dessas oligarquias tradicionais estarem se reinventando para poder se reproduzir. Assim, com a decadência das atividades extrativas da castanha, passam a redirecionar seus capitais para outras atividades modernas, como pecuária melhorada geneticamente, laticínios, frigoríficos, além do beneficiamento de castanha para exportação (EMMI, 1999). Além disso, buscam fazer novas alianças dentro do regime democrático, como se tem visto nas recentes eleições do Pará, em que os mesmos se articularam com antigos inimigos políticos e com candidatos socialdemocratas (EMMI; ACEVEDO MARIN, 1996). 
Ao final dos anos 1990, Marabá apresentava um crescimento de sua área urbana, significativo em relação ao período anterior conforme Mapa 2. 


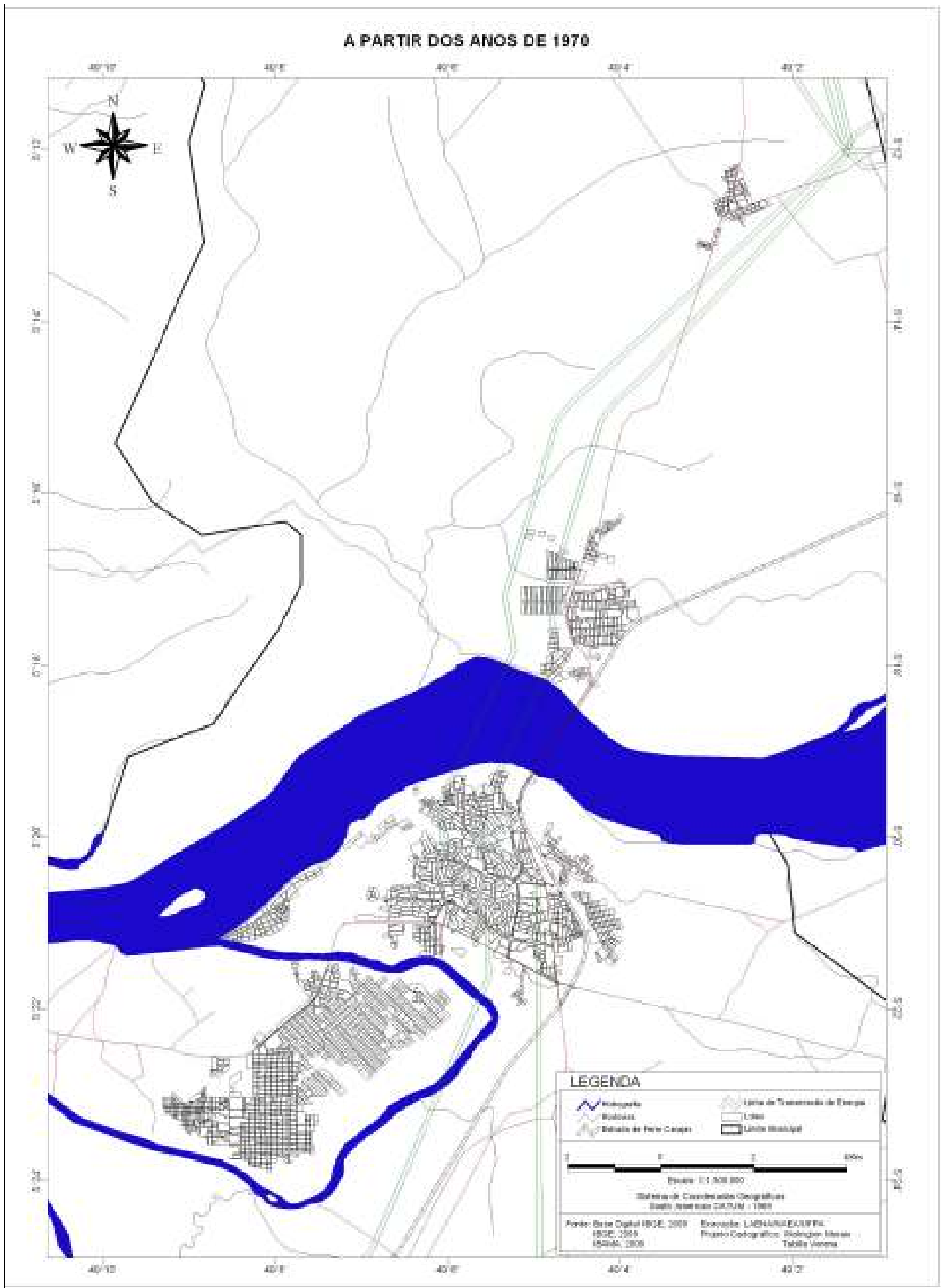

Mapa 2: Expansão urbana de Marabá a partir de 1970 
Nota-se, de acordo com o mapa 2, que as ações de desenvolvimento regional implementadas pelo estado, no caso de Marabá, refletiram também em sua forma urbana, e neste caso, os eixos de circulação foram primordiais para esse crescimento e alterações. Observa-se que os núcleos em que esses eixos (rodovias e ferrovia) foram implantados, são exatamente onde se apresentam as maiores áreas de expansão da cidade - o núcleo Nova Marabá, foi o mais significativo neste aspecto, tendo em vista que ele está localizado exatamente na confluência dos eixos criados a partir das políticas de desenvolvimento regional, quais sejam, a rodovia Transamazônica, a PA-150 e da Estrada de Ferro Carajás; o núcleo Cidade Nova, teve sua expansão ao longo da rodovia Transamazônica, através da colonização do INCRA; o núcleo menor de São Félix, teve sua expansão também ao longo da Transamazônica e da Estrada de Ferro, aqui especialmente por se tratar de um núcleo que está nas proximidades da ponte rodo-ferroviária; além desses, há ainda o surgimento de um novo núcleo, o de Morada Nova, que também encontra-se na confluência de duas importantes rodovias a PA-150 e a BR-222, que fazem a ligação de Marabá com as demais cidades da região e esta última como um eixo de acesso à BR-010 (rodovia Belém-Brasília) - e que no caso do núcleo Pioneiro, foi afetado, no sentido de ter ficado à margem dessa nova dinâmica socioespacial que se criou em Marabá, na mudança de uma "rede urbana dendrítica" para uma "rede urbana complexa" (CORRÊA, 2006).

\subsection{Marabá como centro econômico e político do sudeste paraense}

O terceiro período aqui elencado, para a discussão acerca da formação socioespacial de Marabá é aquele delimitado a partir dos anos 1990 até o período atual. Nesse momento alguns elementos são fundamentais para a compreensão dos processos socioespaciais que vêm se desenvolvendo na região amazônica e particularmente na cidade de Marabá.

O primeiro deles refere-se significativas transformações que a Amazônia sofreu ao longo dos anos, mas especialmente a partir dos anos 1970, a partir, principalmente, de ações estatais e de outros agentes capitalistas, que desencadearam em processos socioespaciais bastante intensos na região. Esses processos, mais recentemente, associam-se ao novo padrão de inserção do Brasil no sistema mundial, que por um lado refere-se às intensas e rápidas transformações do sistema capitalista ao fím do último milênio, e por outro lado pelo esgotamento do sistema nacional-desenvolvimentista e da democratização do país, e esses dois aspectos são materializados em vetores de transformação regional, dentre os quais se identifica o tecno-ecológico (BECKER, 2005). 
Para o entendimento dessa análise, a autora destaca a idéia de uma economia de fronteira, que em termos da relação sociedade-natureza, é o paradigma do capitalismo que se generalizou com a industrialização. E nesse processo, a idéia de progresso é entendida enquanto crescimento econômico e prosperidades infinitas, que se baseiam na exploração de recursos naturais, que são, nessa perspectiva, igualmente infinitos.

No caso da ação estatal do período militar, a economia de fronteira foi levada a cabo, através do desenvolvimento de "uma tecnologia espacial", que impôs ao território uma malha de duplo controle, que era técnico, mas também político, a chamada "malha programada", que era delineada por um conjunto de programas e planos governamentais, que possibilitou a abertura de diversas fronteiras, mas foi na Amazônia, que esse processo desenvolveu-se com maior veemência (BECKER, 2005).

A autora demonstra ainda que, a forma intensa como se implementou a malha programada na região, originaram conflitos sociais e ambientais, o conjunto desses elementos fez com que o paradigma desenvolvimentista baseado na economia de fronteira, fosse alterado para "um padrão de desenvolvimento sustentável baseado na eficiência máxima e no desperdício mínimo no uso dos recursos naturais na valorização da diversidade e na descentralização" (BECKER, 2005, p. 226).

Ainda de acordo com Becker (2005), o vetor tecno-ecológico se desenvolve com maior intensidade e é mais apreensível na Amazônia, nesse novo modelo de produção, a natureza é valorizada como capital de realização futura. Para os sujeitos sociais envolvidos nesse processo, dentre eles as populações nativas e movimentos ambientalistas, de modo geral, ela é vista com um valor de reprodução da vida, por outro lado, ela é vista como recurso para os segmentos produtores e para a população de modo geral.

Nesse sentido, é que o surgimento desse novo vetor, também acaba gerando conflitos de ordem social e territorial, movimentos que Fernandes e Martin (2004) denominam de movimentos sócio-territoriais ${ }^{10}$. Esses movimentos têm duas perspectivas diferentes diante do vetor tecno-ecológico, a primeira refere-se ao grupo dos preservacionistas, que têm ainda interesses diversos, por um lado, buscam preservar a natureza como estoque de vida, e por outro visa preservá-la como reserva de valor; a segunda, concerne ao grupo dos conservacionistas, que são diferentes organizações de produtores que a partir da produção familiar geram novas territorialidades, as quais são fruto de resistências à expropriação, que

\footnotetext{
${ }^{10}$ De acordo com Fernandes e Martin (2004), os movimentos sociais se organizam e dominam territórios. A territorialização, no entanto, não é apenas a luta pela conquista da terra, mas também permite a organização social, a produção de identidades e a luta de classes, elementos que constituem a base desses movimentos sócioterritoriais.
} 
resultam em conflitos (armados ou políticos), como forma de legitimação de suas lutas pelo território (BECKER, 2005).

É nesse sentido que Becker (2004) direciona sua análise, de modo a compreender a dinâmica regional do presente, buscando sua construção histórica. Assim, a autora parte da idéia de que "os surtos voltados para os produtos extrativos de exportação, as estratégias de controle do território e os modelos de ocupação marcaram toda a formação territorial da Amazônia, estando presentes até os dias atuais.” (BECKER, 2004, p. 25) A autora destaca a intensa atuação do Estado no ordenamento territorial da região, principalmente a partir do período de 1966 e 1988, que de acordo com a mesma, é quando se inicia um planejamento regional efetivo:

Foram várias as estratégias territoriais que complementaram a ocupação regional (...) Para tanto, impõe sobre o território uma malha de duplo controle-técnico e político-constituída de todos os tipos de conexões e redes, capaz de controlar fluxos e estoques, e tendo as cidades como base logística para a ação (BECKER, 2004, p. 26)

Segundo Becker (2004), a região amazônica passa por mudanças estruturais que partindo de uma ação combinada de processos globais, nacionais e locais, políticas contraditórias (ambientais e de desenvolvimento), mudam o povoamento da região, dando origem a três confrontos de uso da terra que se demonstram territorialmente, são eles: 1) a reprodução do ciclo de exploração da madeira/expansão da pecuária/desflorestamento; 2) experiências sustentáveis de extrativismo florestal e pesqueiro tradicional melhorados; 3) agropecuária capitalizada.

A partir destes elementos, a rede urbana regional também se redefine, mostrando o novo papel assumido pelas cidades médias, que se voltam para atender essa nova demanda do processo produtivo e delineiam uma nova configuração na organização urbana amazônica, como verificam Trindade Jr e Pereira (2007):

As mudanças ocorridas na organização urbana da Amazônia, segundo nos mostra Corrêa (1987), indicam que até 1960 verificou-se na região um padrão espacial predominantemente dendrítico da rede urbana, com desmesurada primazia de Belém como metrópole regional e uma expressão relativamente pequena da grande maioria dos centros urbanos regionais. Atualmente, o que se verifica é uma ruptura desse padrão, com um forte dinamismo das cidades localizadas, ou que passam a surgir às margens das rodovias, em detrimento de cidades ribeirinhas, bem como uma urbanização concentrada nas capitais estaduais (TRINDADE JR; PEREIRA, 2007, p. 6) 
Desta forma, com o surgimento de uma nova dinâmica regional atrelada principalmente a políticas de planejamento e desenvolvimento regional, tal como afirmou Becker (2004), alguns centros urbanos, que surgem de núcleos urbanos planejados ou que eram antigos núcleos de relativa importância, passam a assumir o papel de centros subregionais, chegando à condição de cidades médias (TRINDADE JR; PEREIRA, 2007, p. 6)

No caso do Estado do Pará, estas políticas de desenvolvimento estavam voltadas para o sentido de uma integração à divisão territorial do trabalho, procurando aumentar a eficiência da economia regional e ao mesmo tempo, integrar o Estado aos demais da Amazônia, e centros como Marabá, Santarém e Castanhal, passam a receber um maior número de migrantes, atrelados a instituições responsáveis pela implementação da nova malha técnica, política e cultural da região (TRINDADE JR; PEREIRA, 2007)

Esta nova dinâmica regional, entretanto não está baseada apenas no fator demográfico, como ressaltam Trindade Jr e Pereira (2007):

O fato de se constituírem em espaços de mediação entre as pequenas cidades e os grandes centros torna-se relevante. Essa mediação, entretanto dá-se em várias dimensões e sentidos, assumindo um caráter regional. (TRINDADE JR; PEREIRA, 2007, p. 10)

Os autores indicam alguns elementos que nos levam a um primeiro entendimento do papel assumido por essas cidades no âmbito regional, quais sejam: o primeiro refere-se aos fluxos, estas cidades servem de referência para as demais inseridas em suas mesorregiões; o segundo diz respeito ao seu papel político, desempenhado junto aos atores locais e mesmo a atores externos à região; o terceiro elemento é o significativo crescimento econômico apresentado por essas cidades na rede urbana regional; um quarto elemento apresentado é concernente ao fluxo migratório destinado às cidades de porte médio (TRINDADE JR; PEREIRA, 2007)

No caso específico da cidade de Marabá, verifica-se que é um município para o qual constantemente se convertem investimentos, além disso, apareceu como a principal cidade comercial e política do sudeste do Pará chegando a estar na quarta posição no ranking econômico estadual. A cidade estabelece uma conexão regional através das redes de aeroportos ligando-a com municípios menores, além de estar no entroncamento do eixo ferroviário e rodoviário do sudeste paraense, com destaque para as rodovias Transamazônica, PA-150, BR-222 e para a ferrovia Ferro-Carajás, que dão a ela uma articulação com municípios oriundos dessa nova dinâmica regional (TRINDADE JR; PEREIRA, 2007). 
Do ponto de vista político, a cidade de Marabá, sua condição geográfica estratégica, que a articula com regiões vizinhas e com outras fora da Amazônia, dão a ela dentro do Estado e da região amazônica, em seguida dos grandes centros urbanos regionais. Há ainda que se considerar neste caso, a formação de oligarquias tradicionais que surgiram em função das frentes pioneiras de atividades extrativas, minerais e vegetais, em especial à castanha (TRINDADE JR; PEREIRA, 2007).

Quanto ao seu papel econômico na rede urbana regional, a cidade de Marabá, assim como as demais cidades médias no Estado, tem grande relevância do ponto de vista de sua capacidade de arrecadação de impostos sobre a circulação de bens e prestação de serviços, que funcionam como fontes para o desenvolvimento de políticas públicas voltadas para o município (TRINDADE JR; PEREIRA, 2007).

No que diz respeito aos fluxos migratórios no Estado do Pará, o sudeste paraense, em que se insere a cidade de Marabá, é apontada como a região para onde se convergem os maiores índices de migração com 58\% (207.772 migrantes). Esse grande contingente que na cidade de Marabá equivale a 6,7\% (23.892 migrantes), explica a desocupação de sua população economicamente ativa, e da precarização da infra-estrutura urbana presente em sua paisagem (TRINDADE JR; PEREIRA, 2007).

Em contraposição as demais cidades médias do país, em que as cidades deste porte apresentam uma melhor qualificação do trabalho e um nível mais elevado de qualidade de vida de sua população, no caso das cidades médias amazônicas, elas tendem a apresentar o empobrecimento de sua população e condições de vida urbana precárias.

Como reflexo dos processos socioespaciais na região, a rede urbana, também tem sua estrutura alterada, e nesse sentido algumas cidades do sudeste paraense sofrem, concomitantemente mudanças em sua dinâmica intra-urbana e inter-regional.

Assim tem-se a intensificação do processo de fragmentação territorial com a formação de municípios desmembrados de Marabá e Parauapebas, como Água Azul do Norte, Eldorado dos Carajás e Canaã dos Carajás; a consolidação de uma rede urbana complexa, com rebatimentos intensos em municípios com maiores níveis de centralidade, a exemplo de Marabá; a expansão de aglomerações urbanas precárias às margens de rodovias, a exemplo de Eldorado dos Carajás e Curionópolis; a expansão do setor terciário em cidades intermediárias, com redes de lojas e supermercados que tendem a estabelecer filiais para outros municípios do sudeste do Pará; um significativo crescimento demográfico da população do sudeste paraense e aumento das desigualdades socioespaciais intra-urbanas; o crescimento da importância e do papel de cidades como Parauapebas e Tucuruí; o recrudescimento de 
conflitos agrários e urbanos, com papel decisivo de resistência empreendida por importantes movimentos sociais, a exemplo do MST.

Para o caso de Marabá, observa-se que, acompanhando essas transformações da rede urbana regional e do sudeste do Pará, ela também reflete essas alterações através da retomada do movimento e do discurso emancipacionista que a projetam enquanto futura capital do estado de Carajás; seu crescimento acelerado, com repercussão na expansão de sua periferia; sua reafirmação como base logística para a expansão de novos agentes capitalistas da região e como centro importante para a projeção de agentes políticos hegemônicos e contrahegemônicos. Do ponto de vista econômico, algumas dinâmicas acabam se reforçando à medida que novos capitais vão se inserindo na cidade e àqueles já presentes, se consolidam com a expansão ou diferenciação de seus setores e áreas de atuação, a exemplo da expansão da segunda etapa do Distrito Industrial de Marabá, que se iniciou a partir de 2005, através da implantação de novas siderúrgicas e da disponibilização de áreas para a instalação de outras indústrias; a presença de filiais de grandes corporações nacionais e internacionais que passam a atuar na região do sudeste paraense, a partir da cidade de Marabá; a manutenção por parte de Marabá da condição de base logística da CVRD. Além disso, o crescimento populacional e a expansão do número de loteamentos e ocupações urbanas, principalmente em suas áreas periféricas, boa parte, em virtude de sua importância como grande entroncamento rodoviário, ferroviário, aeroviário, hidroviário, o que reforça sua centralidade urbano-regional.

No que se refere ao setor terciário há um fortalecimento deste setor na cidade, com a presença de comércios e serviços que atendem a modernização econômica urbana e rural e que define igualmente um circuito inferior e alternativo que a caracterizam como cidade dos agronegócios e das agrosubsistências.

Além disso, a cidade vem passando por um processo de "retorno ao rio", entretanto, o sentido agora do uso do rio, está associado, não apenas através do caráter de sobrevivência dos sujeitos locais, mas de outro modo, para a circulação fluvial das mercadorias produzidas, como uma alternativa para o escoamento da produção local e regional, a partir da construção de um novo porto na cidade e da instalação de uma nova grande empresa do setor industrial, voltada à produção de aço - refere-se à Aços Laminados do Pará (ALPA) -, prevista para entrar em funcionamento em 2011, será localizada na porção oeste do município na margem direita do rio Tocantins.

Outro fator importante para a compreensão da fase atual de Marabá está relacionado às novas políticas de gestão e desenvolvimento do governo estadual, que tem direcionado várias 
ações no sentido de fomentar certa descentralização e dessa maneira, certa "regionalização do desenvolvimento" no estado.

Estas ações são direcionadas a partir da nova regionalização criada pelo governo do estado em detrimento da divisão estabelecida pelo Instituto brasileiro de Geografia e Estatística (IBGE) sob a justificativa de que esta divisão, tem-se apresentado para muitos gestores e estudiosos, como insuficiente para compreender a realidade do território paraense, tendo em vista que sua grande extensão territorial dificulta a articulação e a integração econômica entre suas micro e mesorregiões. Assim, conforme a caracterização dada pela Secretaria de Integração Regional (SEIR) (2009), o entendimento de seu espaço, construído como pertencente a uma única plataforma homogênea de planejamento, torna-se um obstáculo diante da heterogeneidade e da diversidade de dinâmicas socioespaciais que o Estado apresenta. Nesse sentido, com o objetivo de construir um novo modelo de desenvolvimento para o Pará, o poder executivo propôs o estabelecimento do princípio da integração produtiva, social e cultural das sub-regiões paraenses, bem como destas com as demais regiões do país, da América do Sul e do mundo. A partir da Resolução nº 002 de 5 de fevereiro de 2004, o Governo do Estado criou uma nova regionalização do território paraense e, com o Decreto $\mathrm{n}^{\circ}$ 1.066 de 19 de junho de 2008, tal regionalização instituída passou a denominar-se Regiões de Integração. Dessa forma, com o estabelecimento das doze novas regiões de integração atualiza-se o planejamento do desenvolvimento, que assume função estratégica no que se refere aos grandes investimentos infraestuturais em conjunto com mecanismos adequados para a gestão do desenvolvimento regional e local e o estímulo ao desenvolvimento da capacidade de governança da sociedade nos múltiplos territórios do Estado (SEIR, 2009). No que se trata de gestão política, o poder executivo a partir da Lei $\mathrm{N}^{0} 7.024$, de 24 de julho de 2007, criou também a Secretaria de Integração Regional, que busca resgatar as relações entre governo estadual, municípios e a sociedade. (SEIR, 2009)

No processo de definição e identificação das 12 Regiões de Integração, levou-se em consideração características como: concentração populacional, acessibilidade, complementaridade e interdependência econômica. Ao todo foram utilizados doze indicadores que permitiram uma versão preliminar para a regionalização do Estado, são eles: Densidade Populacional (IBGE 2000); Concentração de Localidades (GEOPARÁ 2002); Repasse de ICMS (SEFA / $2^{\circ}$ semestre de 2002); Renda per capita (IBGE 1991); Acessibilidade física (SIGIEP 2002); Consumo de Energia Elétrica (Rede Celpa 2002); Leitos por mil habitantes (DATASUS / SEEPS); Índice de Desenvolvimento Humano - IDH (PNUD 2000), Telefonia Fixa (Telemar 2002); Índice de Alfabetização (IBGE 2000) e Fatores Geopolíticos. A partir 
do cruzamento desses dados, as 12 Regiões de Integração foram definidas e hierarquizadas em 4 níveis, em função de seu grau de acessibilidade, de dinâmica econômica, ocupação populacional e nível de acesso a equipamentos básicos e conectividade, conforme quadro a seguir:

\begin{tabular}{|l|l|}
\hline Nível 01 & $\begin{array}{l}\text { 1. Região Metropolitana (5 municípios) } \\
\text { 2. Região Guamá (18 municípios) } \\
\text { 3. Região Rio Caeté (15 municípios) }\end{array}$ \\
\hline Nível 02 & $\begin{array}{l}\text { 4. Região Araguaia (15 municípios) } \\
\text { 5. Região Carajás (12 municípios) } \\
\text { 6. Região Tocantins (11 municípios) } \\
\text { 7. Região Baixo Amazonas (12 } \\
\text { municípios) }\end{array}$ \\
\hline Nível 03 & $\begin{array}{l}\text { 8. Região Lago de Tucuruí (7 municípios) } \\
\text { 9. Região Rio Capim (16 municípios) }\end{array}$ \\
\hline 10. Região Xingu (10 municípios)
\end{tabular}

Quadro 1: Divisão das regiões de integração em níveis de agregação Fonte: SEIR, 2009.

Partindo dessa nova regionalização, as políticas públicas do governo do estado, têm se desenvolvido no sentido fomentar essa descentralização e de desenvolvimento regional. Para tanto, cada uma das regiões de integração tem como base algumas cidades consideradas pólos regionais, que em sua grande maioria são cidades de médio porte, a exemplo da cidade de Marabá, pólo da região Carajás, que recebeu e vem recebendo novos fixos, como uma das sedes regionais da própria SEIR, a criação de um parque de ciência e tecnologia - no caso dos parques de C\&T criados no estado, apenas as cidades de Marabá, Santarém e Belém foram beneficiadas -, e ainda é um dos locais de atuação do projeto Navega Pará ${ }^{11}$, bem como projetos de infraestrutura urbana e habitação.

\footnotetext{
${ }^{11}$ Este projeto foi criado pelo governo do estado, com o intuito de interligar por internet de alta velocidade, a partir de cinco ações básicas, os principais órgãos administrativos do Estado, viabilizando ações como teleeducação, tele-negócios e inclusão digital. As ações básicas do NavegaPará são as seguintes: Metrobel Utilização da rede de fibra óptica Metrobel para interligar, por internet de alta velocidade, cerca de 300 unidades
} 
Essas ações, ainda que pontuais, têm permitido, de certa maneira, o fortalecimento das cidades médias do estado, já que a maior parte delas desenvolve-se exatamente em cidades como Marabá e Santarém, que já possuem uma centralidade regional, a partir de suas dinâmicas intra-urbanas, e fomentando ainda mais a ação dos movimentos separatistas regionais (criação do estado de Carajás, com capital Marabá, e do estado do Tapajós, tendo por capital Santarém), tendo em vista que, as maiores áreas produtivas do Estado estão concentradas exatamente na região de influência dessas duas cidades, e por outro lado, a concentração dos investimentos em infra-estrutura e serviços, ainda se faz apenas na região Metropolitana, em detrimento das demais regiões, e nesse sentido, as ações do estado têm sido voltadas em sua maioria, para atividades produtivas nessas áreas, com pouco ou nenhum investimento em sua infraestrutura e melhoria na qualidade dos serviços.

Com o desenvolvimento de todos esses processos socioespaciais ao longo desses três grandes períodos, tem como produto a configuração de Marabá como uma cidade polinucleada, e o desenho de uma forma urbana com três centros urbanos principais (Marabá Pioneira, Nova Marabá e Cidade Nova) e dois secundários (São Félix e Morada Nova), e, além disso, a inserção dessa nova atividade produtiva tem conduzido a novas tendências de expansão urbana a partir da instalação da ALPA. (mapa 3)

administrativas. Principais áreas beneficiadas: segurança, saúde e educação; Infovias - Integração do Estado com a interligação dos principais órgãos públicos a partir de convênio para utilizar 1.800 quilômetros de fibra óptica da Eletronorte. As infovias são uma rede macro de transmissão, da qual é necessário baixar o sinal para utilização em serviços públicos; Cidades Digitais - Construção de pequenas redes para que se baixe o sinal da Eletronorte, interligando os principais órgãos públicos (federais, estaduais e municipais), como escolas, hospitais e delegacias; Infocentros públicos - Serão construídos infocentros em 13 municípios, disponibilizando internet de alta velocidade para dois milhões de pessoas no interior; Telecentros de negócios - será realizada a capacitação e qualificação, além de seminários e debates à distância de setores produtivos. A Secretaria da Fazenda ampliará o projeto original, construindo telecentros de negócios nos principais pólos econômicos, para utilização por sindicatos, empresas, cooperativas e associações. 


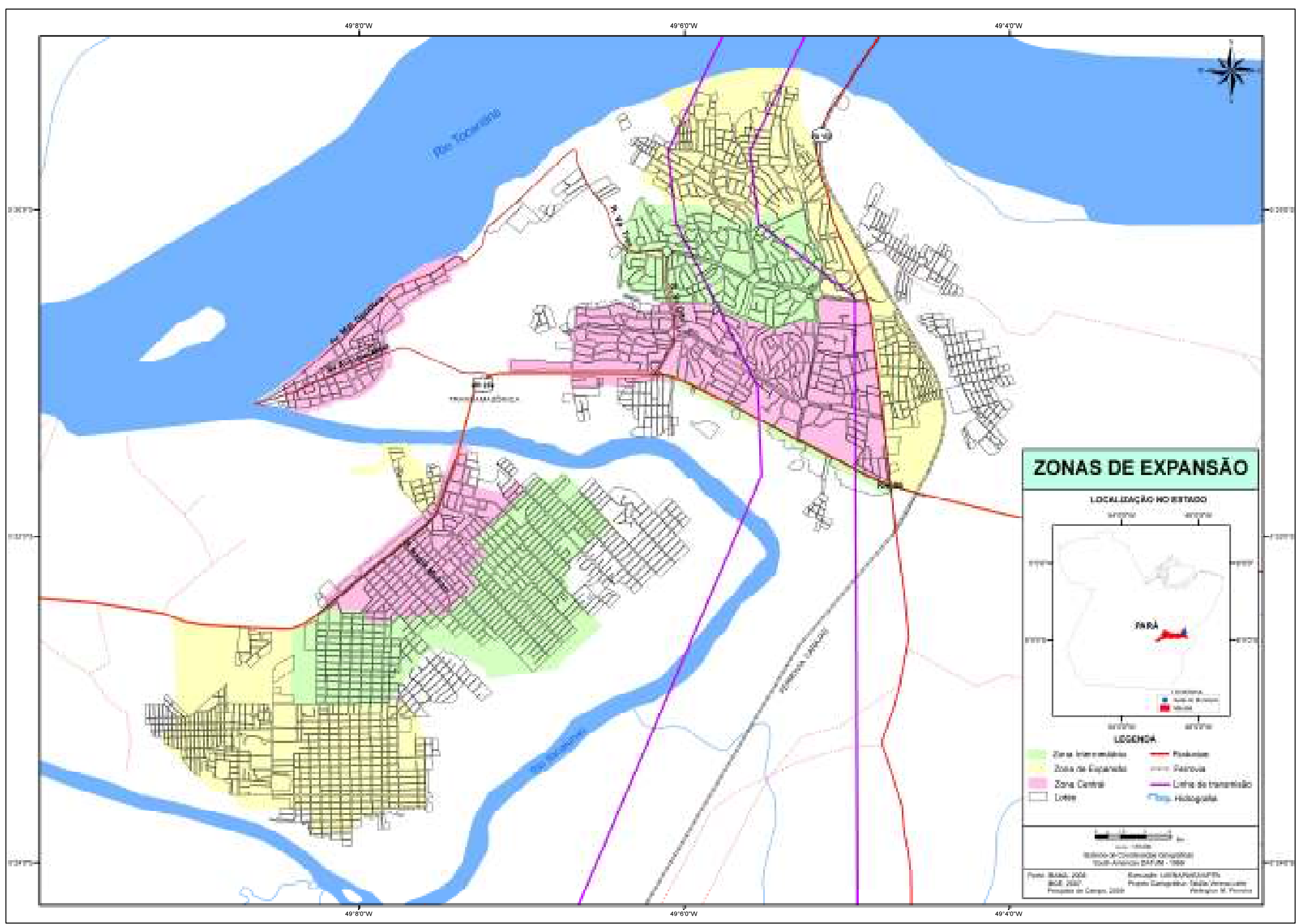

Mapa 3: Expansão urbana de Marabá após 1990 
Na fase atual do desenvolvimento urbano de Marabá, os núcleos até então definidos e delimitados no mapa 3, tratam da dinâmica intra-urbana do município de Marabá, que foram se delineando ao longo do tempo e que configuraram a morfologia ${ }^{12}$ da cidade nesse último período.

No mapa 4 observamos a distribuição espacial dessa morfologia urbana, ressaltando que o município possui ainda grandes áreas rurais, mas sua dinâmica econômica é predominantemente urbana, com destaque para o setor industrial e de serviços como anteriormente tratado. Nota-se ainda que, as três principais centralidades urbanas situam-se nas proximidades dos eixos de circulação, sejam eles fluviais ou rodoviários

Além das três centralidades, identificamos ainda uma dinâmica mais recente na cidade, trata-se da zona de expansão, dessa maneira temos quatro principais dinâmicas intra-urbanas, quais sejam: o Distrito Marabá Pioneira, o Distrito Nova Marabá, o Distrito Cidade Nova, e a área da expansão urbana identificada pelos bairros São Félix, Morada Nova e o Km 6 da rodovia Transamazônica que corta o município. Esses vetores da expansão urbana podem ser visualizados no mapa 5. É importante destacar ainda, a importância do Distrito Industrial nessa dinâmica, tendo em vista que marca substancialmente a economia do município. Essa divisão distrital pode ser visualizada no mapa 6.

\footnotetext{
${ }^{12}$ Sobre isso, Sposito 2004, define a morfologia urbana, não apenas como as formas espaciais, mas também, como as relações desencadeadas no âmbito interno das cidades dão lugar e funções à essas formas. Nesse sentido, a morfologia aqui tratada, permite compreender a organização interna das cidades a partir de suas formas e relações a ela intrínsecas. (SPOSITO, 2004)
} 


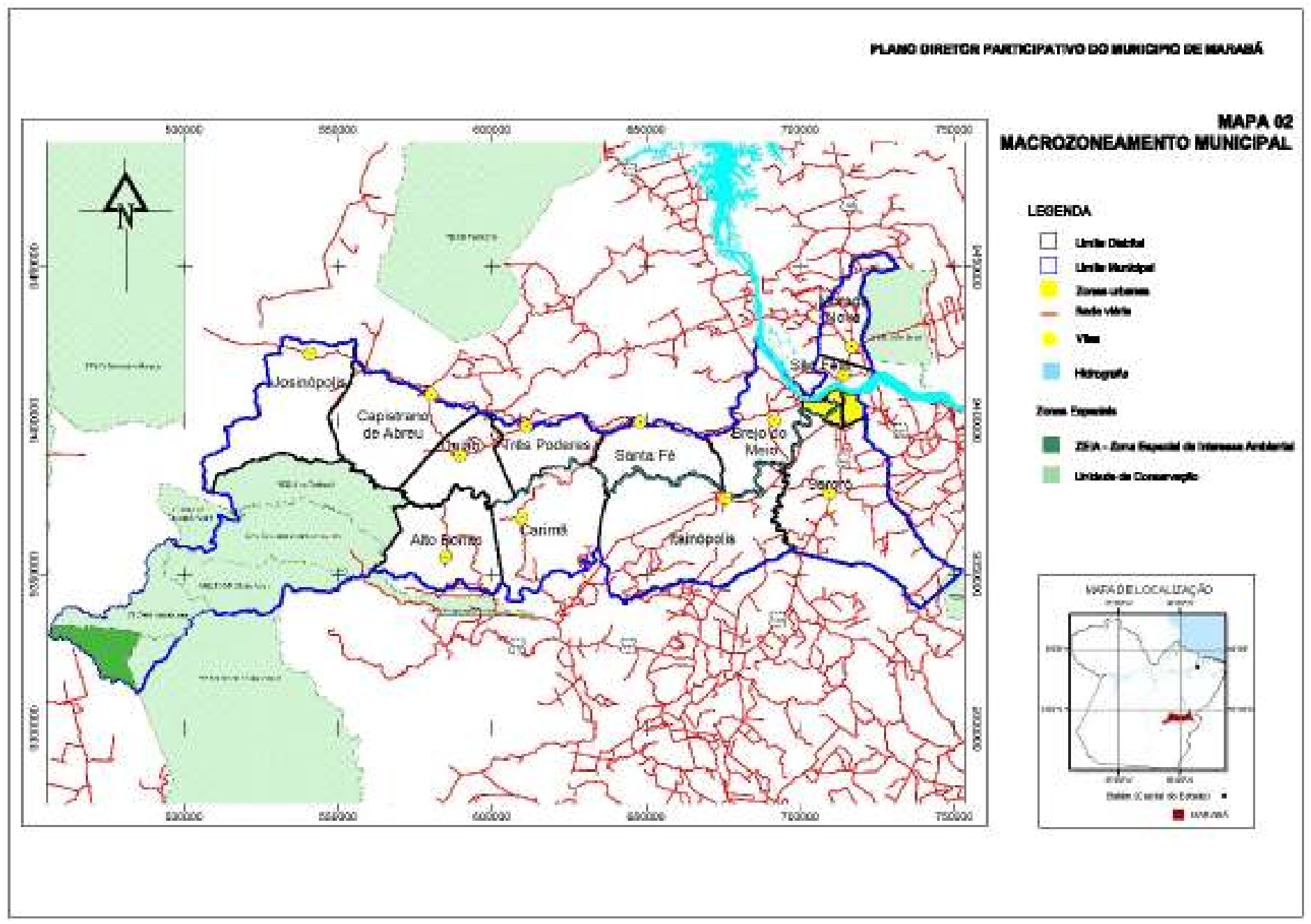

Mapa 4: Macrozoneamento Municipal de Marabá Fonte: Prefeitura de Marabá, 2006. 


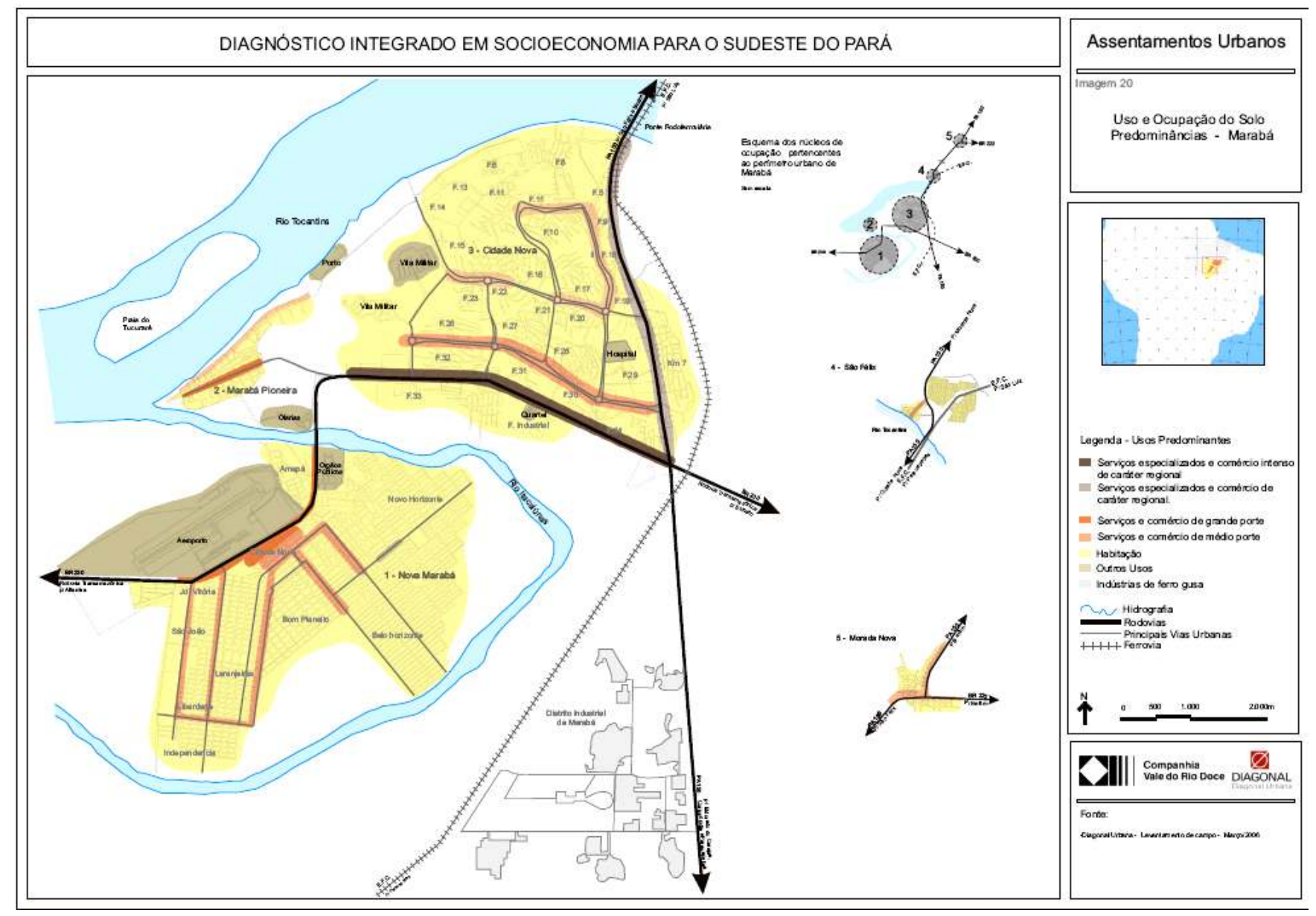

Mapa 5: Vetores de Expansão Urbana do Município de Marabá

Fonte: Companhia Vale do Rio Doce. Diagonal Urbana. Diagnóstico integrado em socioeconomia para o sudeste do Pará. Belém, 2007. 


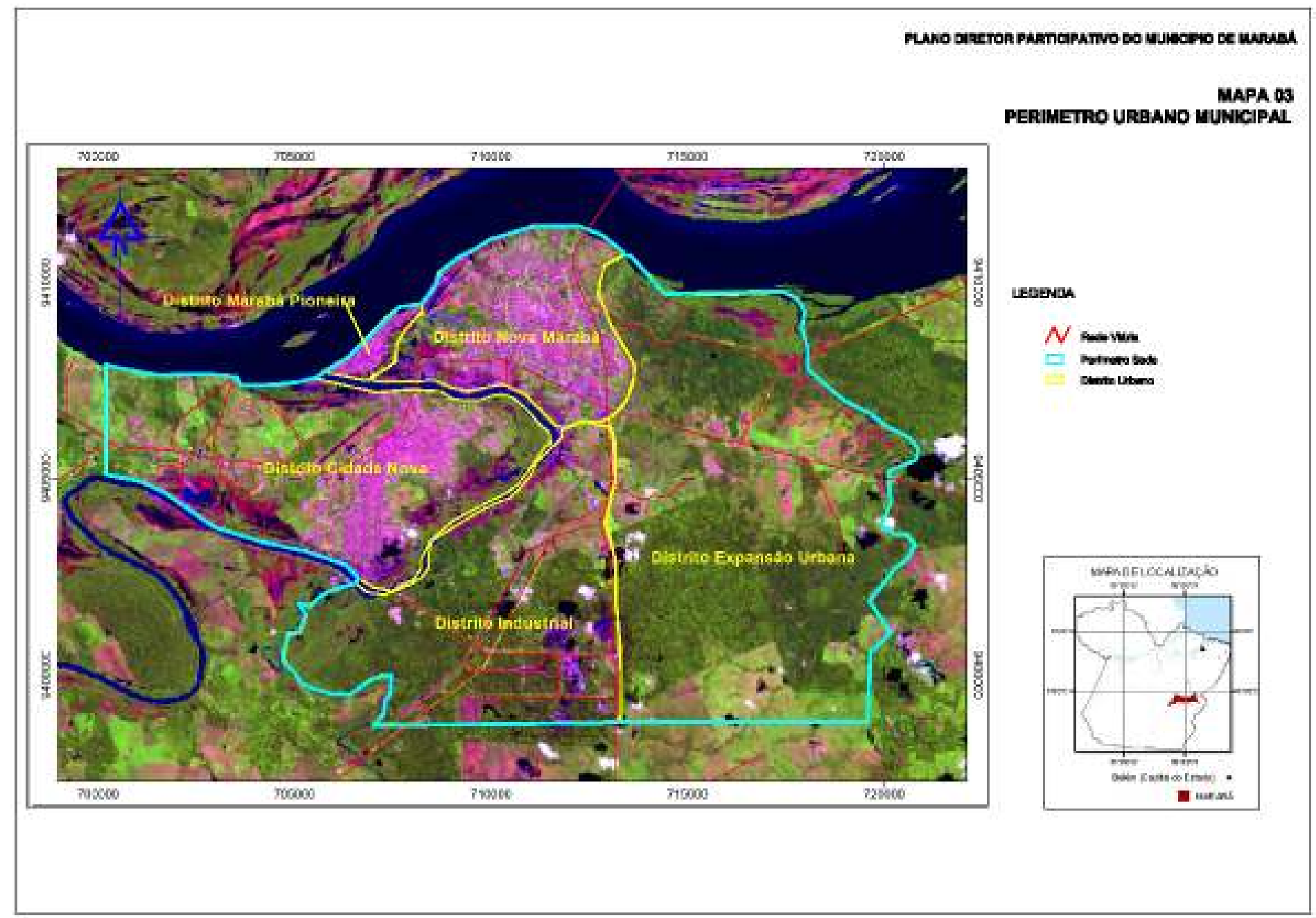

Mapa 6: Zonas Urbanas do Município de Marabá Fonte: Prefeitura de Marabá, 2006. 


\subsubsection{O distrito Marabá Pioneira ou Velha Marabá}

O Distrito Marabá Pioneira, tal como explicitado anteriormente, é núcleo de ocupação original do município de Marabá, formado ainda no século XIX, foi um importante ponto de circulação de produtos regionais, teve sua dinâmica econômica marcada pela extração da castanha-do-pará durante um longo período, sendo uma importante área de exploração deste produto.

Atualmente esse núcleo ainda mantém sua característica original voltada ao setor de serviços e comércio, abrigando o comércio formal e informal, tendo ainda grande importância o setor turístico, tendo em vista sua localização à margem do rio Tocantins e a orla fluvial da cidade construída com a finalidade de fomentar essa atividade.

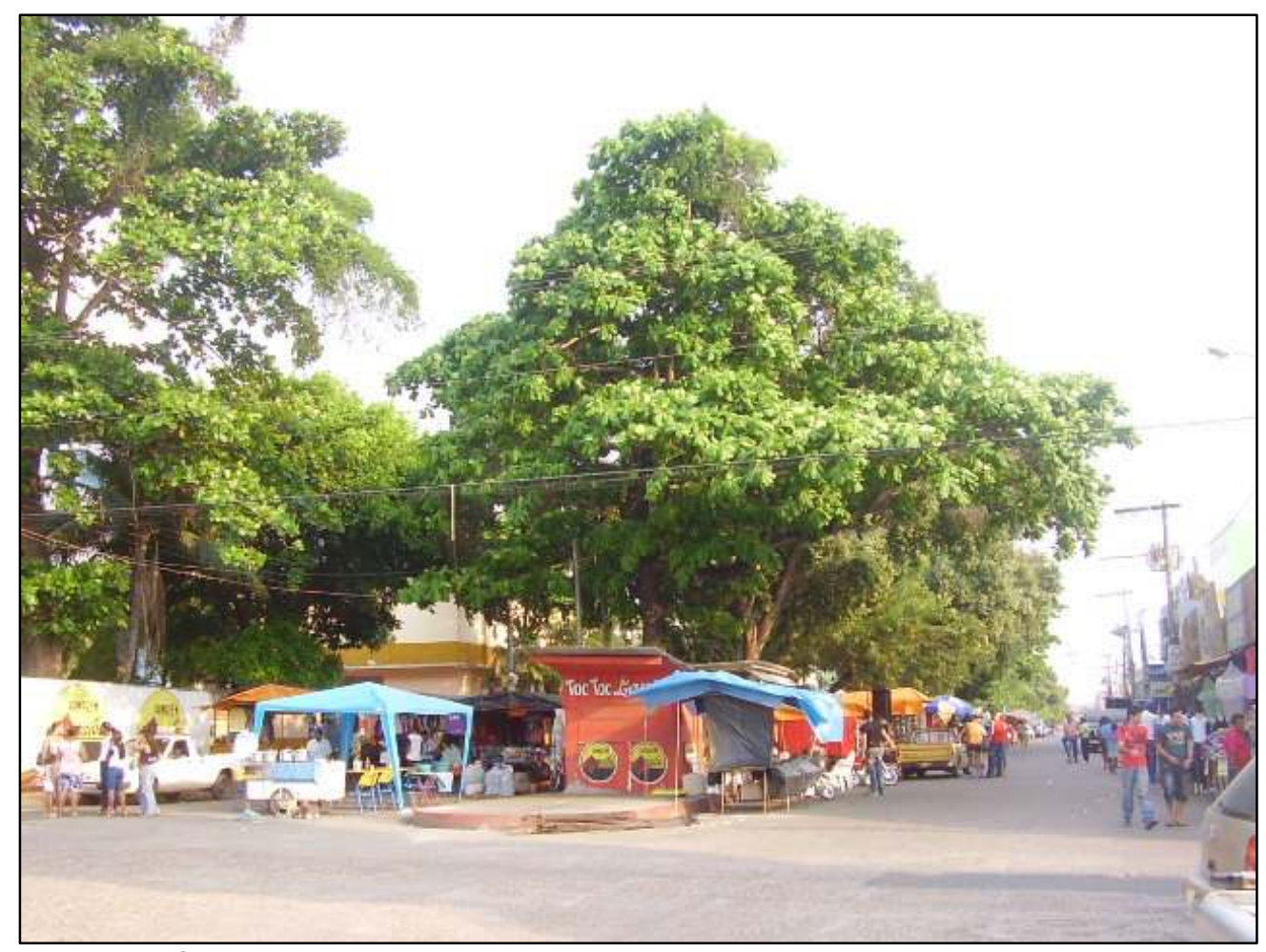

Foto 6: Área de comércio informal no centro do Distrito Marabá Pioneira

Fonte: Ribeiro, R. (Trabalho de campo/outubro de 2008)

Comentário: área de comércio informal no Distrito Marabá Pioneira, esta é uma área central neste distrito na qual há também comércio formal e onde funcionam as sedes de associações (comerciais e de trabalhadores), bem como serviços financeiros. 


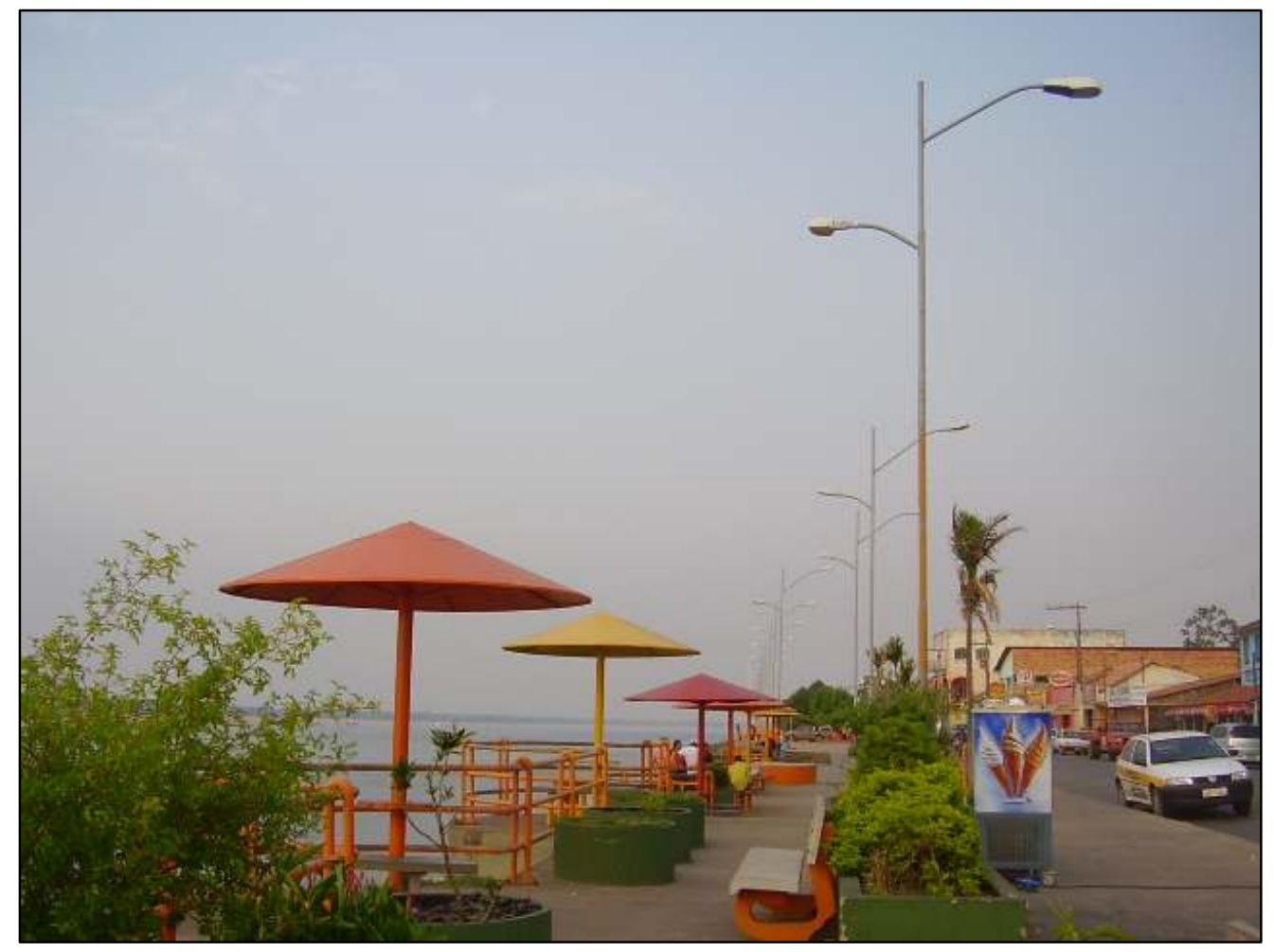

Foto 7: Orla Fluvial da cidade de Marabá

Fonte: Ribeiro, R. (Trabalho de campo/outubro de 2008)

Comentário: Orla da cidade de Marabá. Espaço de lazer e turismo à margem do rio Tocantins, muito visitado no chamado período de verão, com o possível uso de praias como a do Tucunaré, em função do baixo nível do rio.

\subsubsection{O distrito Nova Marabá}

O Distrito Nova Marabá é o terceiro núcleo de ocupação urbana. Trata-se da área objeto de planejamento da (SUDAM), com o intuito de remanejar a população do Núcleo Pioneiro em função das constantes enchentes do rio Tocantins, com ocupação desordenada no entorno com o aumento da população e as crescentes migrações para o município.

Este núcleo concentra grande parte das instituições municipais, estaduais e federais, de gestão e ensino ${ }^{13}$, bem como grande parte das instituições financeiras, de serviços e comércio de

\footnotetext{
${ }^{13}$ As instituições de ensino estão listadas no quadro 3.
} 
médio porte, bem como o terminal rodoviário, estão alocados nesse núcleo. Além disso, é o núcleo que está no entroncamento dos principais eixos de circulação que ligam Marabá à região e ao restante do país, funcionando, dessa forma, como um dos principais pontos de circulação de capitais, serviços e pessoas do município, sendo fundamental para o entendimento dessa dinâmica intra-urbana.

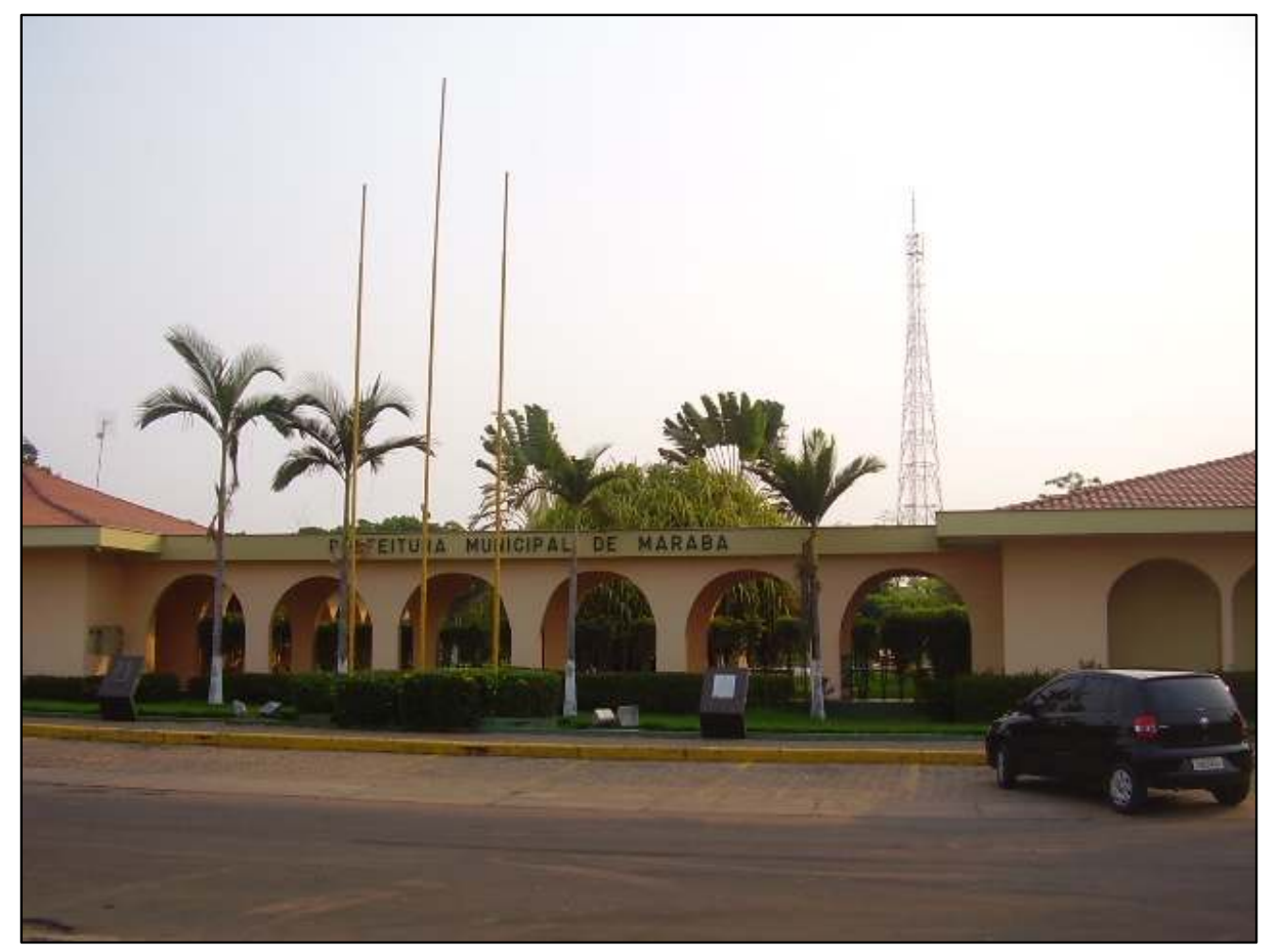

Foto 8: Prefeitura Municipal de Marabá

Fonte: Ribeiro, R. (Trabalho de campo/outubro de 2008)

Comentário: Sede administrativa da Prefeitura do município de Marabá, na qual funcionam também as secretarias de administração (SEAD) e de planejamento e desenvolvimento urbano (SEDURB). 


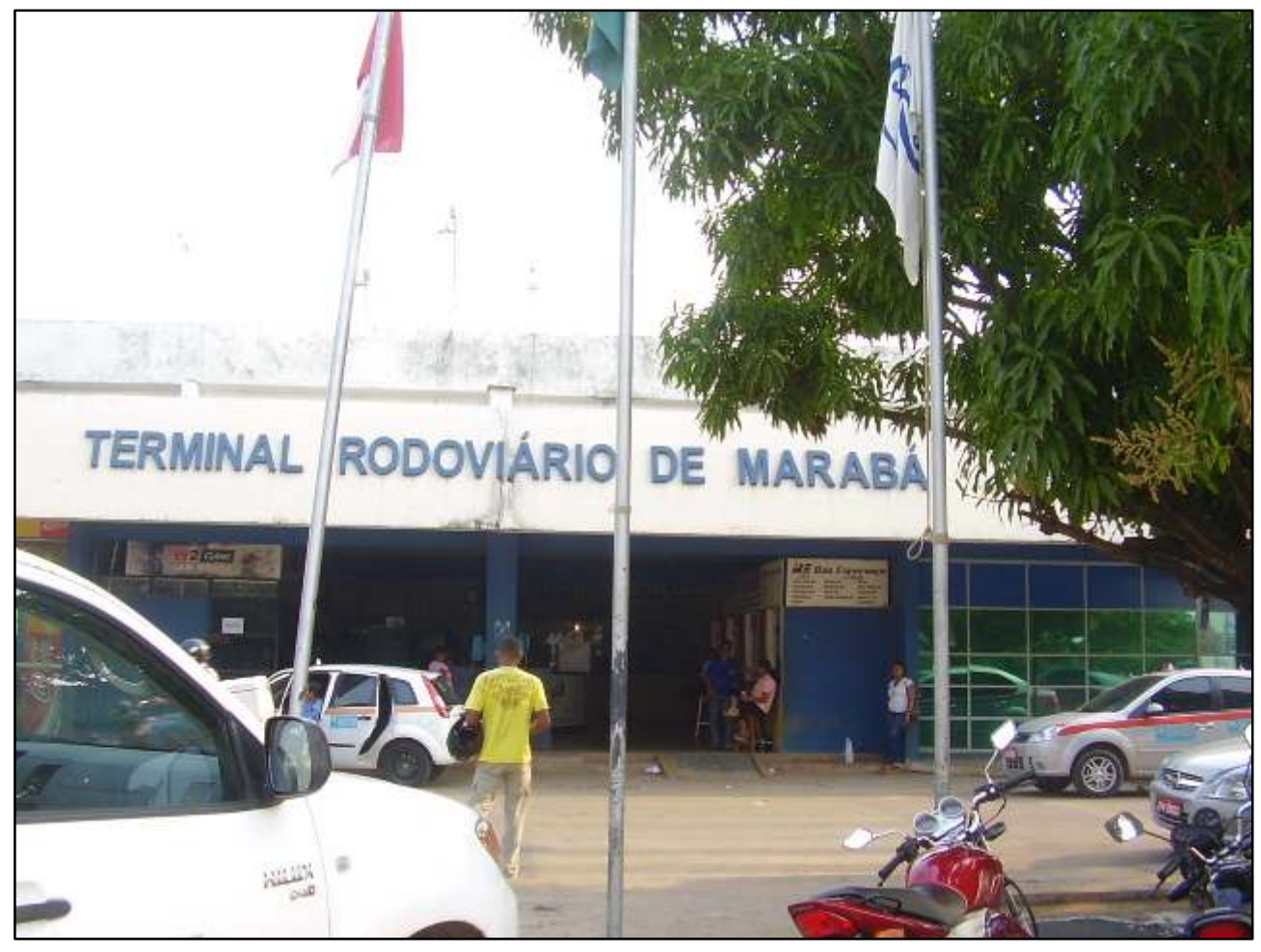

Foto 9: Terminal Rodoviário de Marabá

Fonte: Ribeiro, R. (Trabalho de campo/outubro de 2008)

Comentário: O terminal rodoviário de Marabá localiza-se no distrito Nova Marabá. Este recebe fluxo de passageiros da capital e do interior do Estado (através de ônibus e vans), bem como de outras regiões e Estados brasileiros.

\subsubsection{O distrito Cidade Nova}

O Núcleo Cidade Nova, como dito anteriormente, surgiu a partir da ocupação rural existente na área, da presença da Agrópole do INCRA, onde se localiza a sede da superintendência regional de Marabá, da instalação do aeroporto, e da construção pela Companhia de Habitação do Estado (COHAB), do conjunto Cidade Nova, articulados à outra margem do rio Itacaiúnas através da ponte da Rodovia Transamazônica (eixo articulador dos usos e assentamentos citados). As terras onde hoje se desenvolve o núcleo Cidade Nova estiveram nas mãos de fazendeiros que promoveram loteamentos, que no seu traçado original avançaram sobre brejos e sobre a cota 80 , conforme informações da Secretaria de Planejamento Urbano da Prefeitura Municipal de Marabá. 


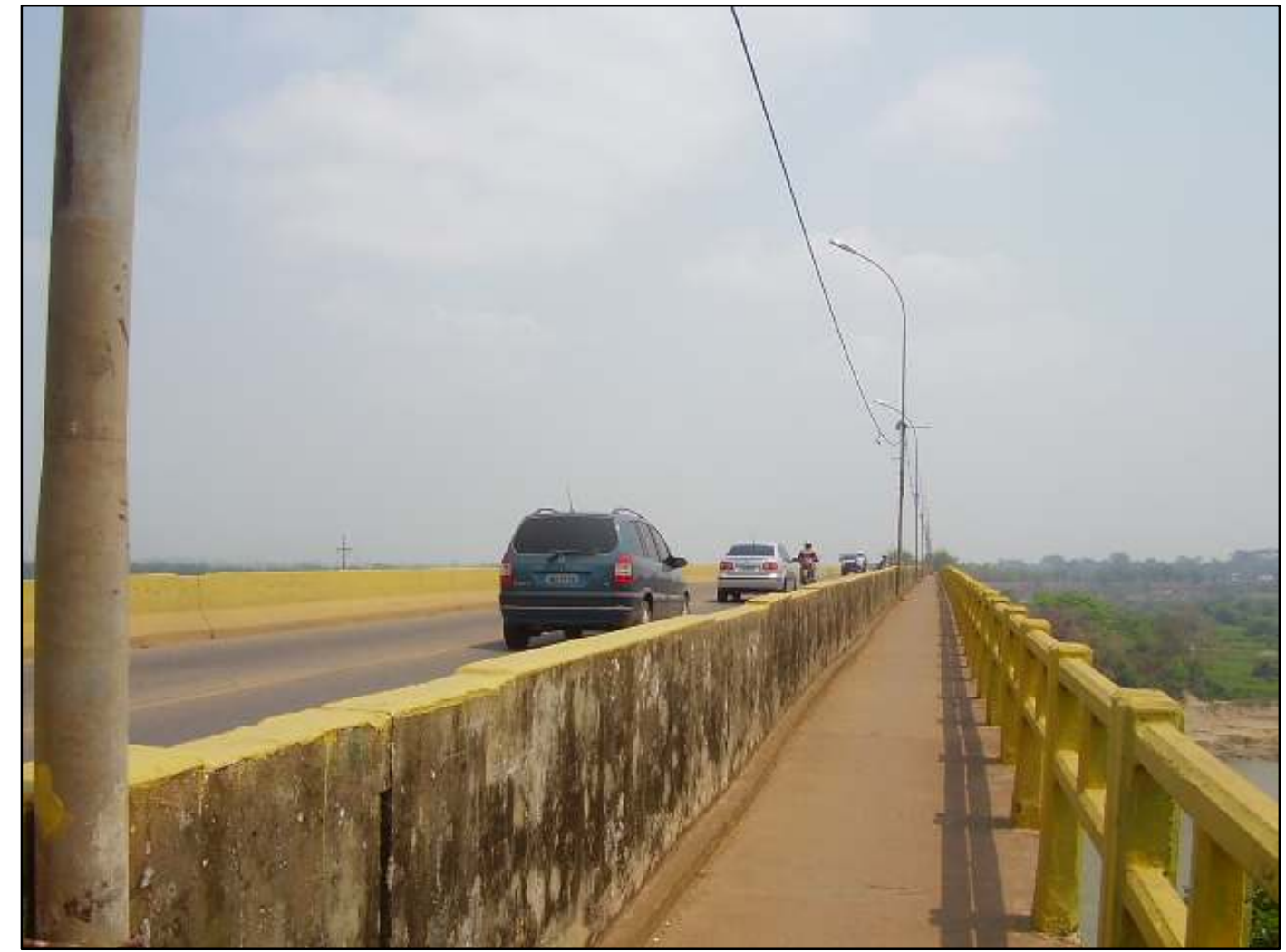

Foto 10: Ponte sobre o rio Itacaiúnas

Fonte: Ribeiro, R. (Trabalho de campo/outubro de 2008)

Comentário: Esta ponte localiza-se no Distrito Cidade Nova e promove a interligação deste distrito com os de Nova Marabá e Marabá Pioneira.

Este núcleo caracteriza-se ainda, por uma dinâmica econômica voltada predominantemente ao setor de comércio e serviços, é nele que se localiza a matriz de lojas de departamentos (GRUPO LEOLAR), filiais de redes regionais do setor farmacêutico (redes BIG BEM e EXTRA FARMA), instituições financeiras, bem como a concentração do setor hoteleiro e ainda a localização do aeroporto de Marabá. É nesse sentido, também um importante eixo de circulação, especialmente no que se refere ao fluxo de pessoas. 


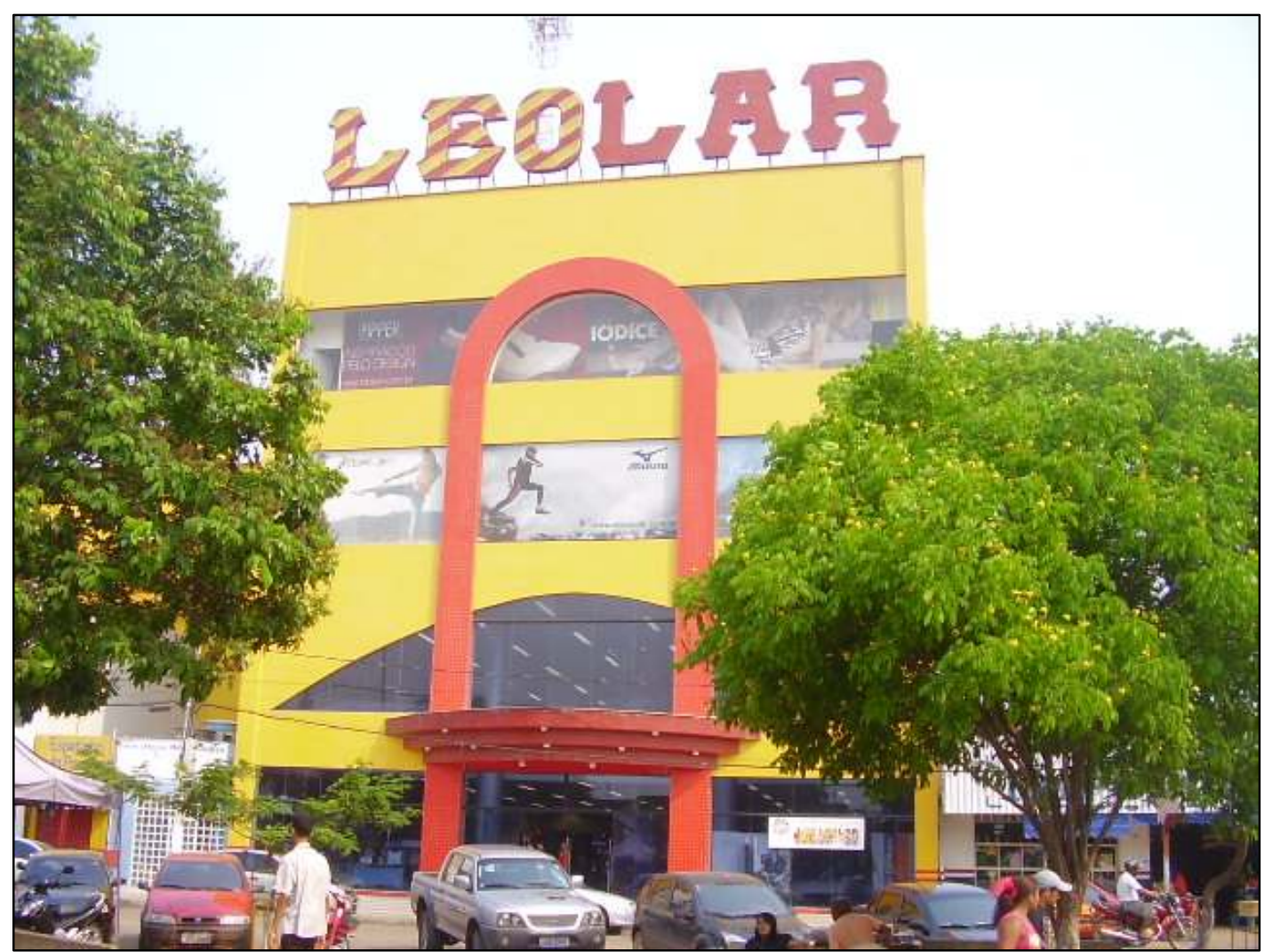

Foto 11:Loja de departamento no Distrito Cidade Nova Fonte: Ribeiro, R. (Trabalho de campo/outubro de 2008)

Comentário: Esta é uma loja de departamentos de uma rede regional pertencente ao Grupo Leolar, que também possui investimentos na indústria siderúrgica na região. 


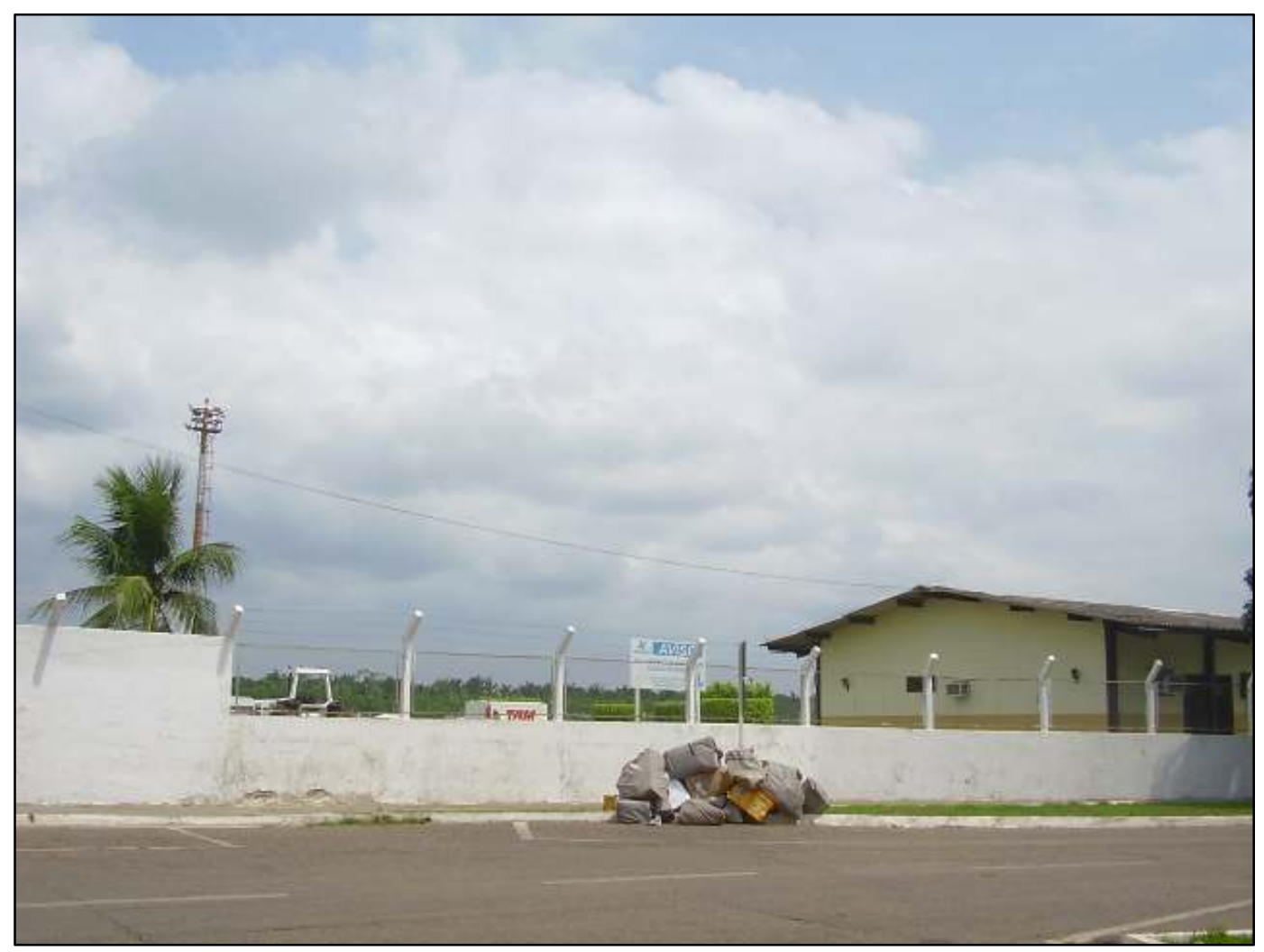

Foto 12: Aeroporto de Marabá

Fonte: Ribeiro, R. (Trabalho de campo/outubro de 2008)

Comentário: O aeroporto de Marabá localiza-se no Distrito Cidade Nova, é operado pela INFRAERO desde 1980, com uma capacidade para até 80.000 passageiros por ano para vôos nacionais e internacionais. Tem uma área de $3.350 .767,05 \mathrm{~m}^{2}$, com uma pista de dimensões $2.000 \mathrm{x}$ $45 \mathrm{~m}^{2}$.

\subsubsection{O distrito Industrial}

Através da Companhia de Desenvolvimento Industrial do Pará - CDI, foi instalado no final da década de oitenta, numa área de 1.300 hectares, o Distrito Industrial de Marabá - DIM, cujo objetivo era a criação de um pólo siderúrgico no Pará para a industrialização do minério de ferro de Carajás, explorado pela Companhia Vale do Rio Doce - CVRD. Inicialmente foram implantados pelas empresas SIMARA e COSIPAR, dois projetos de ferro-gusa. Outros projetos, previstos nessa época, foram instalados em Açailândia no Maranhão. Depois de dez anos outros projetos começaram a serem implantados. Hoje existem seis empresas funcionando e seis projetos em fase de implantação, para funcionar em 2005/2006 e outros em fase de negociação. 
As empresas do setor geram atualmente cerca de 2.460 empregos diretos e cerca de 8 mil empregos na atividade carvoeira, esta em toda a região Sul e Sudeste do Pará. O crescimento e a verticalização da indústria siderúrgica, depende da solução de problemas logísticos (transporte) e energético (carvão vegetal de reflorestamento substituindo o uso da floresta nativa), além da superação da atual crise do mercado externo (PREFEITURA DE MARABÁ, 2006).

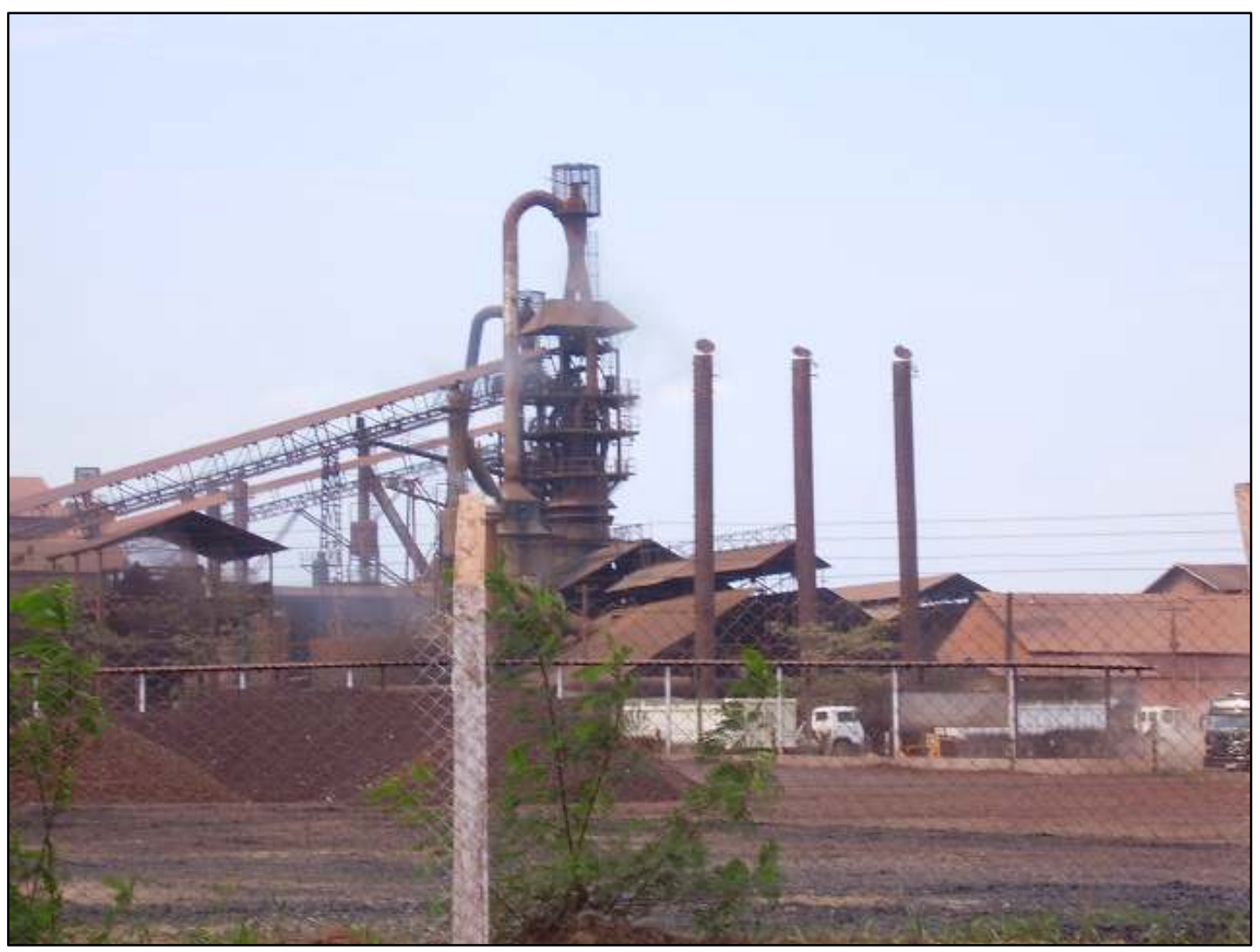

Foto 13: Pátio da Companhia Siderúrgica do Pará - COSIPAR

Fonte: Ribeiro, R. (Trabalho de campo/outubro de 2008)

Comentário: Esta é uma das indústrias mais importantes do parque industrial de município de Marabá, estando entre as cinco mais relevantes junto à Associação Comercial e Industrial de Marabá (ACIM). 


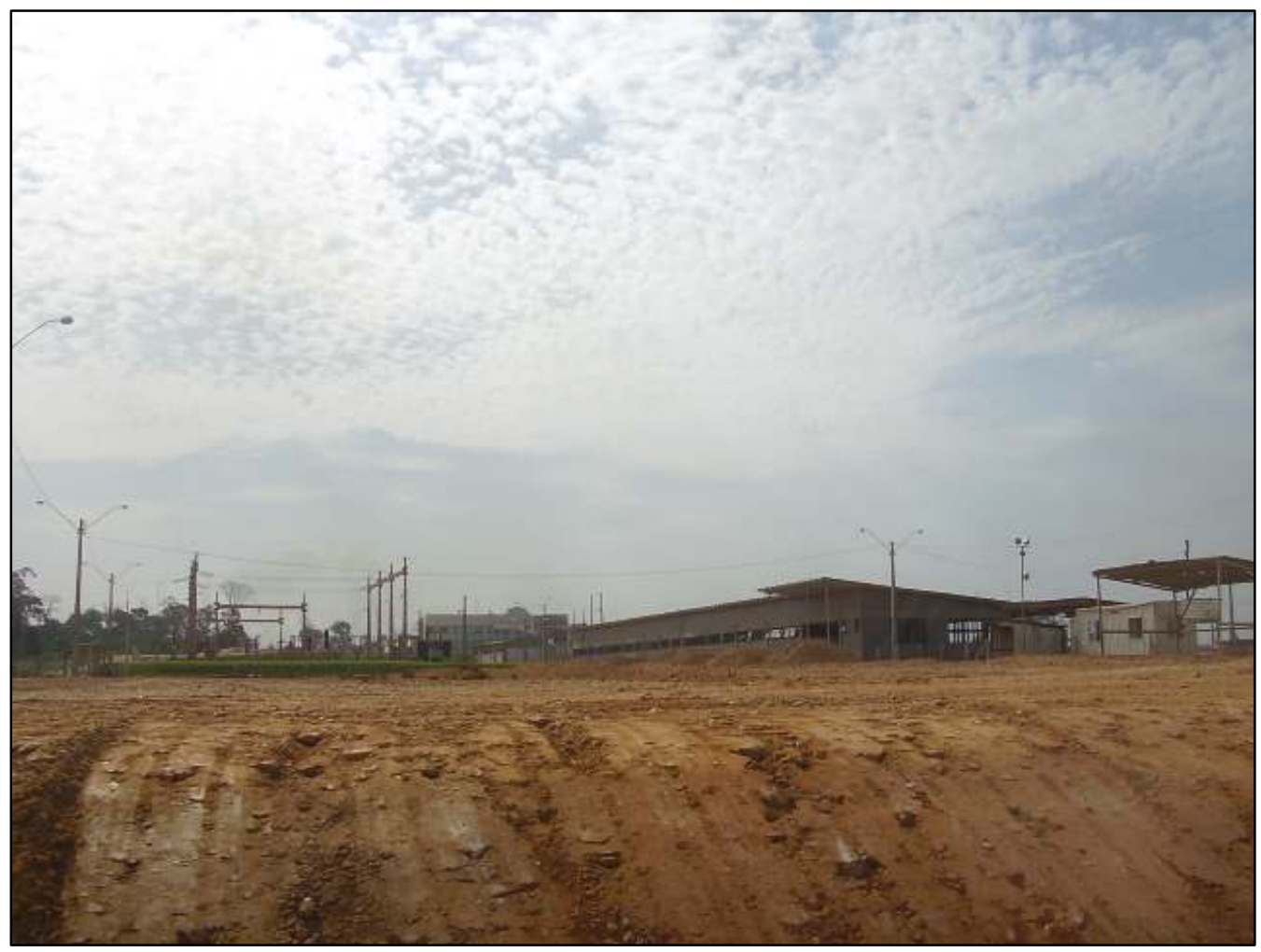

Foto 14: Pátio da Siderúrgica Norte Brasil S. A. - SINOBRAS

Fonte: Ribeiro, R. (Trabalho de campo/outubro de 2008)

Comentário: Área de construção da Siderúrgica Norte Brasil S. A (SINOBRAS), obra implementada com recursos do governo federal e da Companhia Vale do Rio Doce, sendo até o presente momento a indústria com a mais avançada tecnologia do setor siderúrgico na região. 


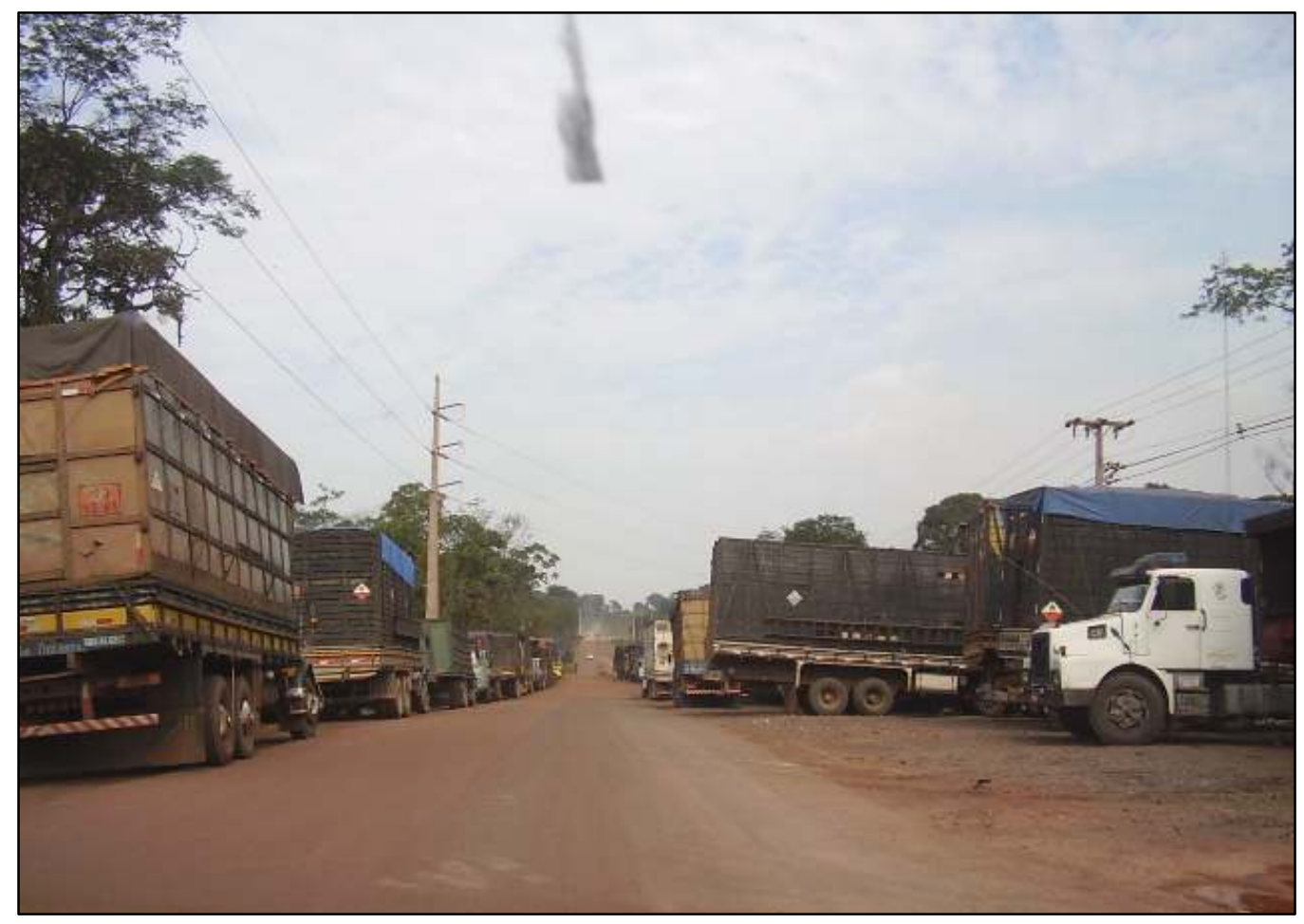

Foto 15: Caminhões de transporte de Carvão Vegetal

Fonte: Ribeiro, R. (Trabalho de campo/outubro de 2008)

Comentário: Estes caminhões realizam o transporte de carvão vegetal de todo o Estado para o município de Marabá, sendo este fonte de energia para a transformação do ferro gusa nas indústrias siderúrgicas.

\subsubsection{O distrito de Expansão Urbana: São Félix, Km 6 e Morada Nova}

Essa área é a que tem uma ocupação mais recente em Marabá, a exceção do bairro São Félix, que já tinha uma pequena ocupação ainda no segundo período aqui delimitado na formação socioespacial de Marabá - a Marabá da castanha -, em virtude de sua localização na margem do Tocantins na parte frontal à Marabá Pioneira, mas que teve uma expansão acelerada após a construção do eixo da ponte rodo-ferroviária, já que se encontra em seu entorno.

\section{O núcleo São Félix}

O bairro São Félix caracteriza-se por ser uma área de expansão urbana mais próxima aos núcleos urbanos centrais da cidade, abriga a população mais carente do entorno e atualmente começam a aparecer nesta área projetos de habitação de alto padrão econômico. É também área 
de lazer, visto sua localização à margem do rio Tocantins e do Igarapé Geladinho, sendo uma área de bastante fluxo de turismo, mas mantendo ainda um caráter de vivência para a população local, pois usam essa área ainda para fins domésticos (como a lavagem de roupas e louças na beira do rio), bem como para atividades de lazer e sobrevivência (como o banho e a pesca).

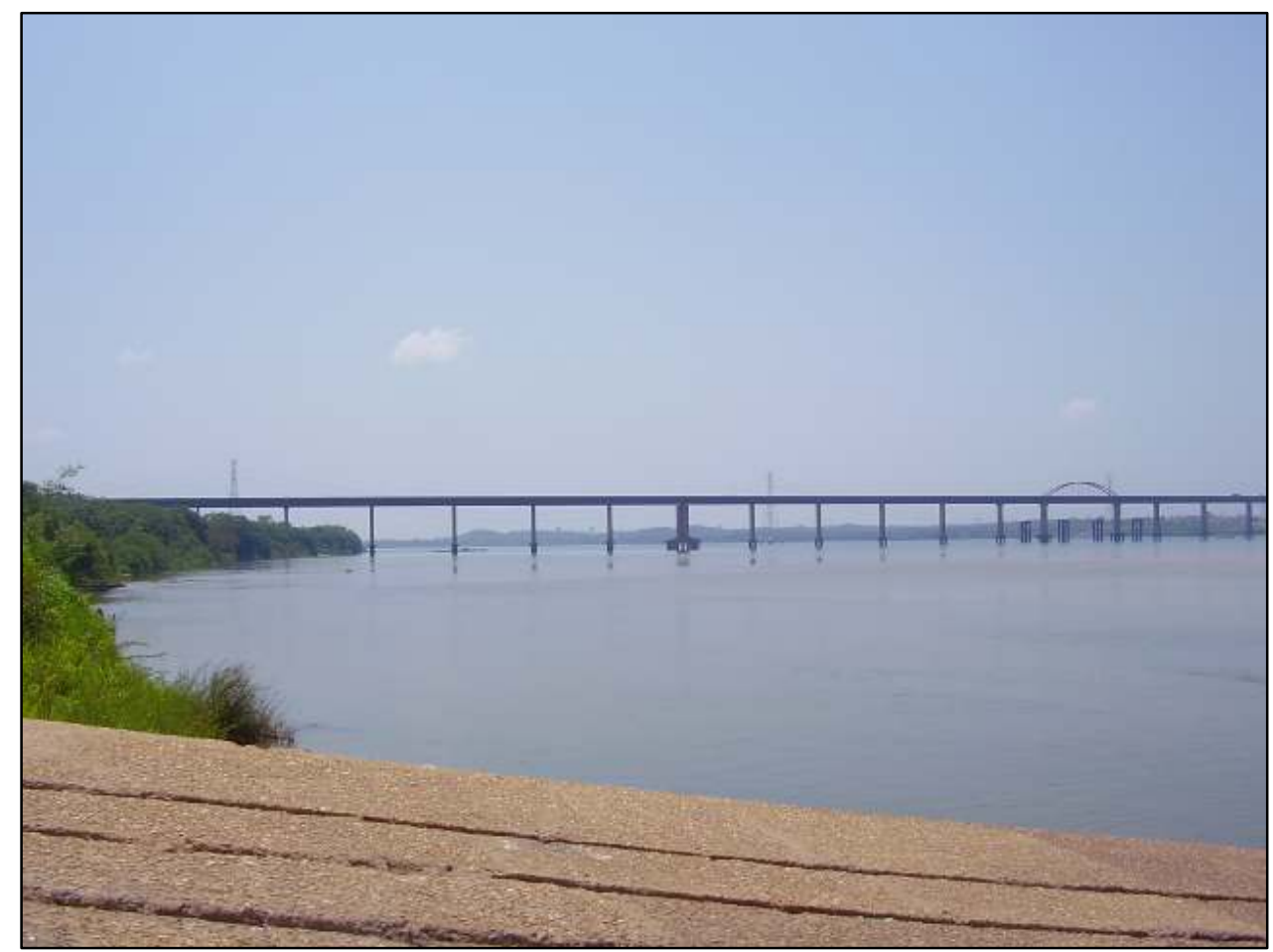

Foto 16: Ponte rodo-ferroviária sobre o rio Tocantins

Fonte: Ribeiro, R. (Trabalho de campo/outubro de 2008)

Comentário: Esta ponte liga o município de Marabá aos demais da região, permitindo fluxos de pessoas e serviços, bem como serve para o escoamento da produção municipal. Sendo ainda fundamental no circuito da produção do ferro na região, pois é um trecho da Estrada de Ferro Carajás, que liga o município de Parauapebas no Pará ao Porto de Itaqui em São Luís no Maranhão. 


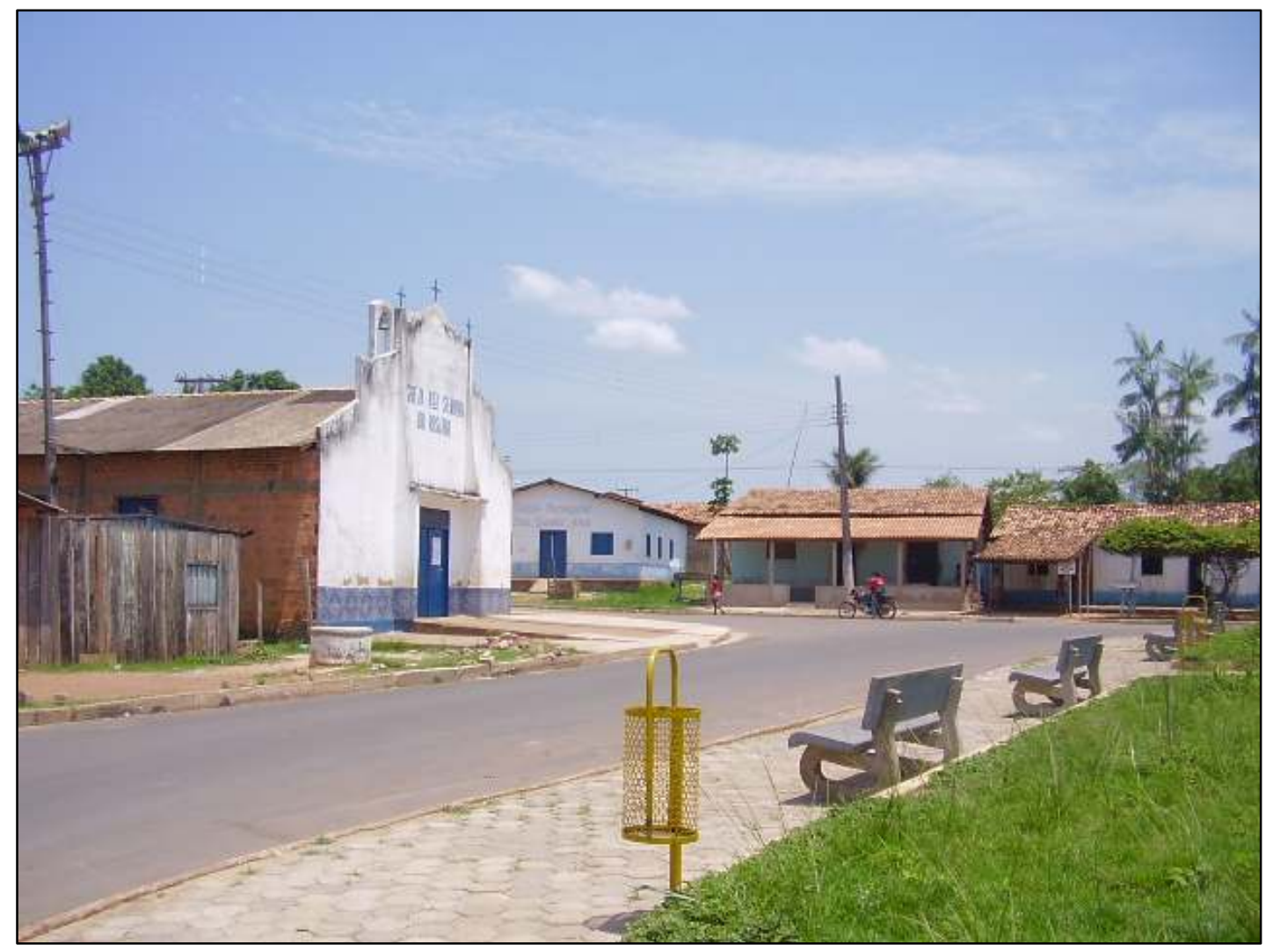

Foto 17: Praça no Bairro São Félix

Fonte: Ribeiro, R. (Trabalho de campo/outubro de 2008)

Comentário: Esta área localiza-se nas proximidades da Praia do Tucunaré, relativamente urbanizada, entretanto, é uma área alagável, em virtude de margear o rio Tocantins. 


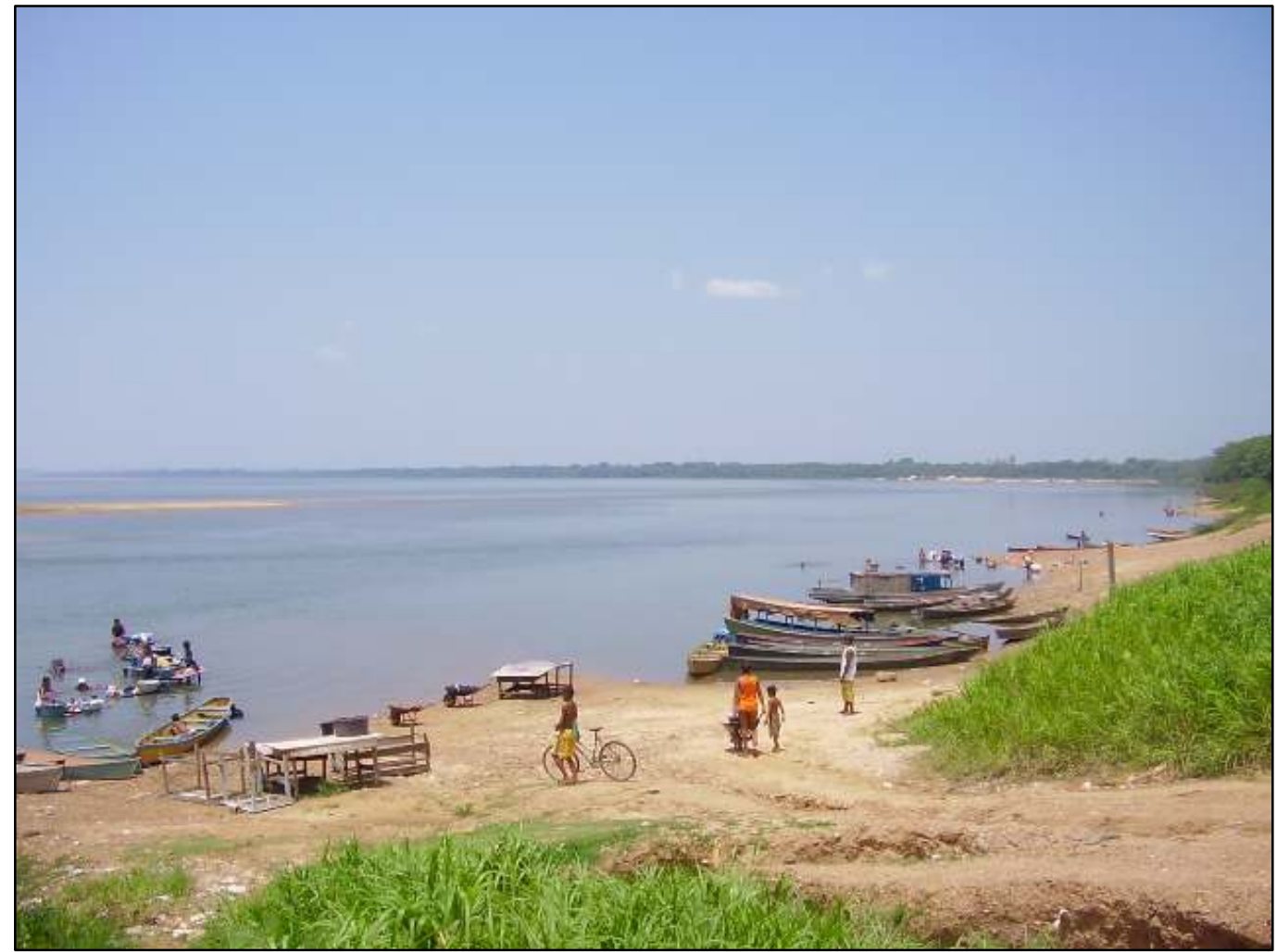

Foto 18: População do bairro São Félix

Fonte: Ribeiro, R. (Trabalho de campo/outubro de 2008)

Comentário: Praia do Geladinho, local de atividades cotidianas da população do Bairro São Félix, onde as pessoas costumam pescar, tomar banho, lavar roupas etc.

\section{O núcleo Quilômetro - 6}

O Km 6 da Rodovia Transamazônica, caracteriza-se por ser um ponto de conexão entre o núcleo urbano de Marabá e as rodovias de acesso aos municípios do entorno, por esta razão nele situa-se o Hospital Regional do Sudeste paraense, sendo também uma área de oferta de serviços de maior porte, como lojas de revenda e manutenção de caminhões e maquinário pesado (Volkswagen, Mercedez Bens, Massei Fergusson, Scania etc), bem como há atividades voltadas para o setor agropecuário, como a empresa ZOOFLORA, voltada para o desenvolvimento de técnicas de inseminação artificial, e o Parque de Exposições Agropecuárias do município, onde anualmente acontece a feira e comercialização dos produtos deste setor de atividade. 


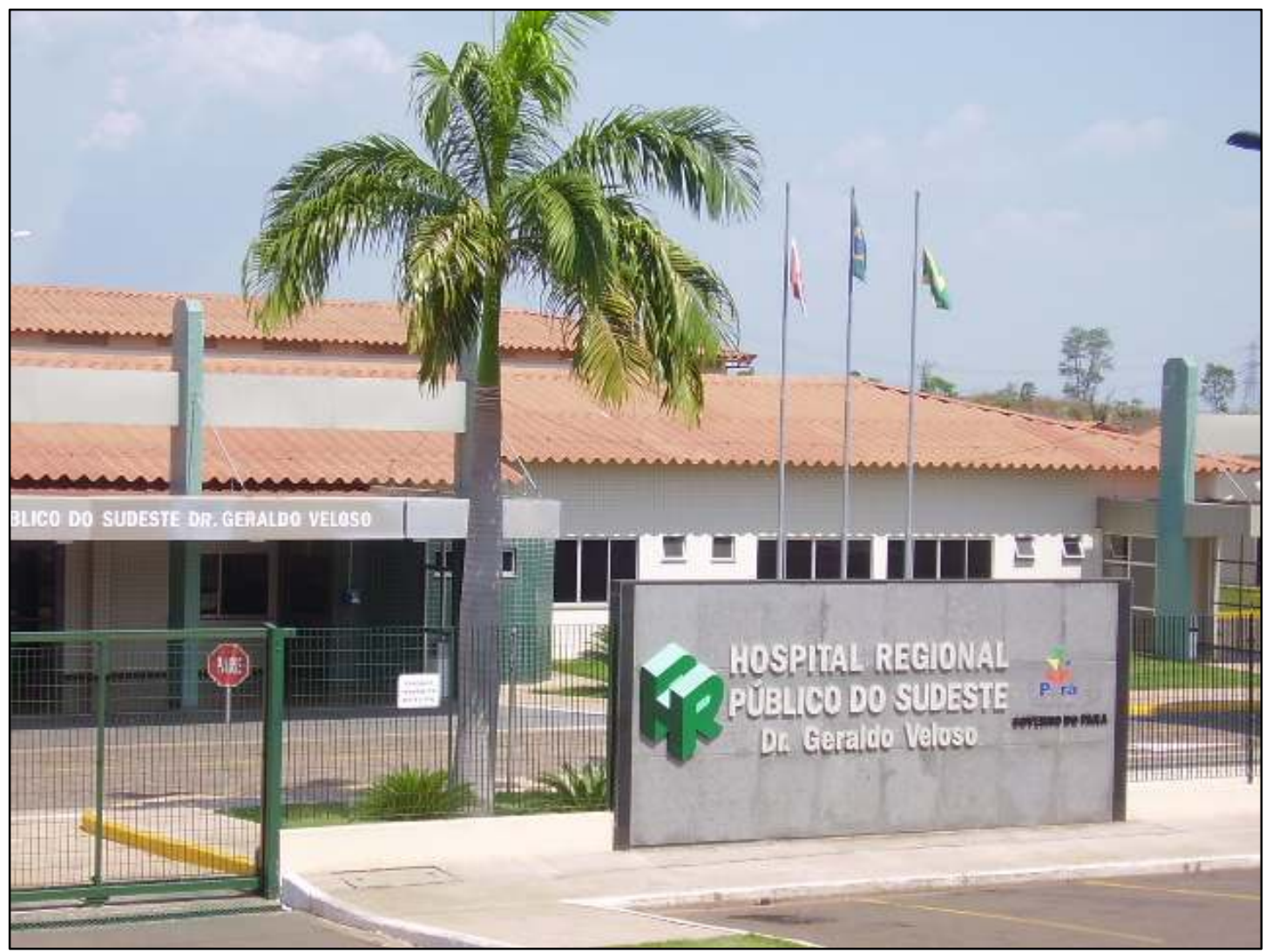

Foto 19: Hospital Regional do Sudeste do Pará

Fonte: Ribeiro, R. (Trabalho de campo/outubro de 2008)

Comentário: O Hospital Regional do Sudeste do Pará Dr. Geraldo Veloso, foi inaugurado em outubro de 2006, faz parte da $11^{\text {a }}$ Regional de Saúde e Proteção Social e abrange aproximadamente 520 mil habitantes em 21 municípios. Com 74 leitos operacionais, divididos em pediatria, obstetrícia de alto risco, clínica médica, clínica cirúrgica e Unidades de Tratamentos Intensivos (UTI) pediátricos, neonatal e adulto, com capacidade para 296 internações/mês. 


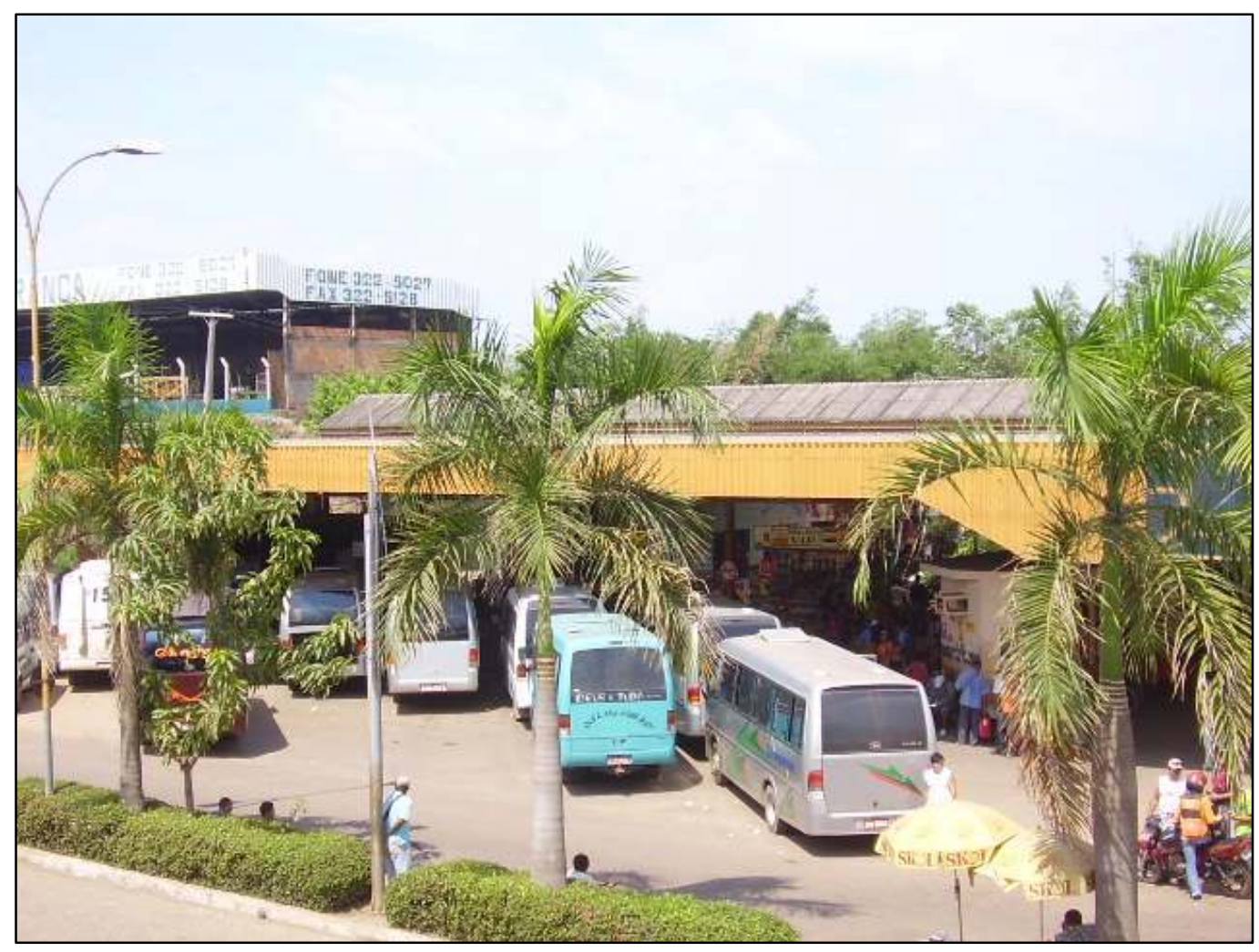

Foto 20: Terminal Rodo-Ferroviário de Marabá

Fonte: Ribeiro, R. (Trabalho de campo/outubro de 2008)

Comentário: Este terminal localiza-se no Km 6 da rodovia Transamazônica. Oferece o serviço de vendas de passagens ferroviárias, bem como oferece serviços de transporte de ônibus e vans para os municípios do entorno.

\section{O núcleo Morada Nova}

O núcleo Morada Nova surgiu no entroncamento da BR-222 (ex- PA-70) com a rodovia PA-150. Dista $12 \mathrm{~km}$ da sede municipal. Hoje conta com uma população de 11.118 habitantes, 1.569 casas. Caracterizado por uma economia atrelada ao setor verejista (possui pequenos mercados, papelarias, posto de revenda de combustível etc), neste local há ainda indústria de laticínios, movelarias e serrarias. Este núcleo ainda possui bastante dependência dos serviços da área mais central de Marabá, como escolas, hospitais etc, bem como acesso ao lazer e emprego. 


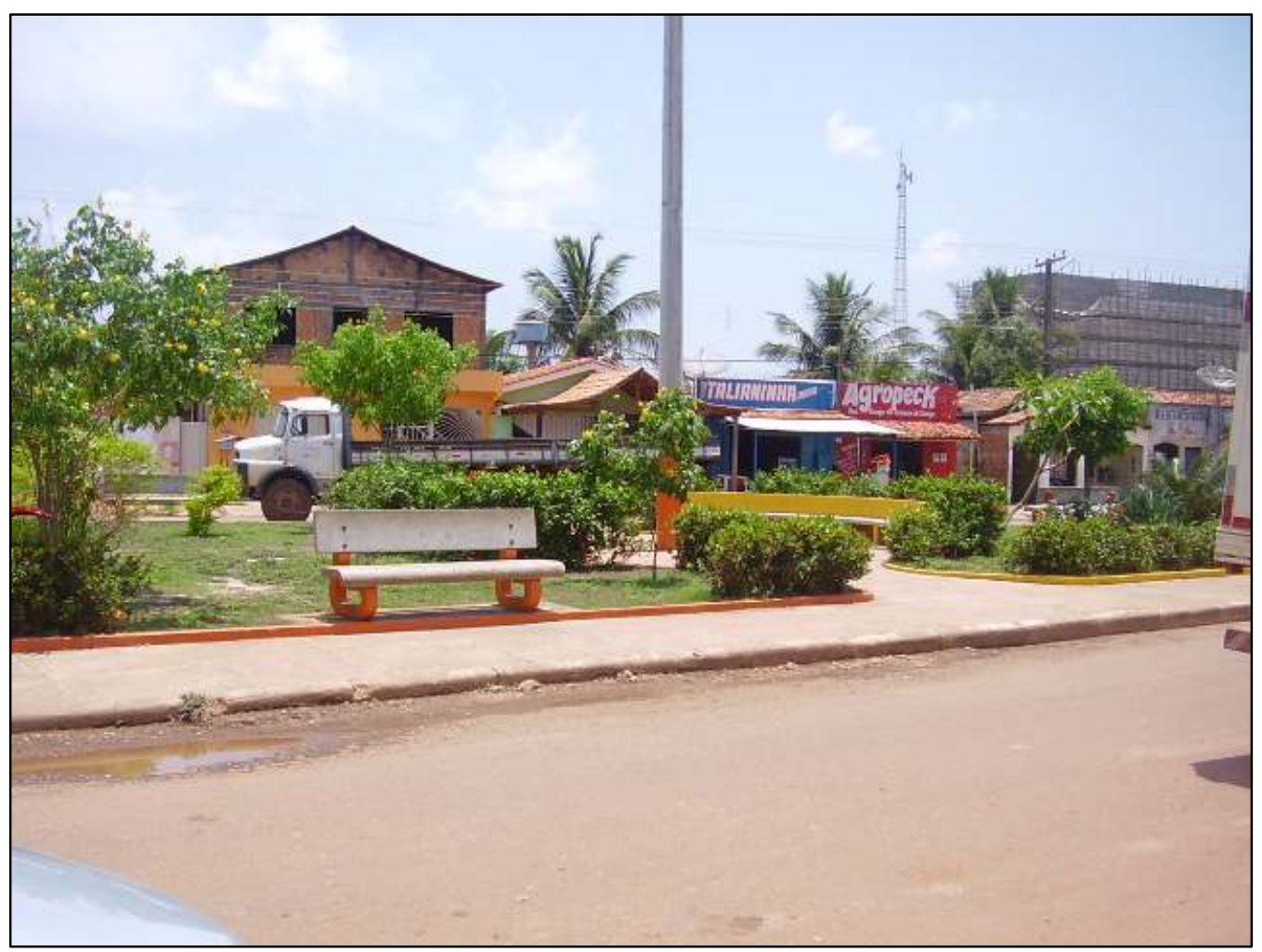

Foto 21: Praça no Bairro Morada Nova

Fonte: Ribeiro, R. (Trabalho de campo/outubro de 2008)

Comentário: Praça localizada no Bairro Morada Nova, na zona de expansão da cidade e proximidades do entroncamento das rodovias BR-222 e PA-150, eixos de interligação com os demais municípios e a capital do Estado. 


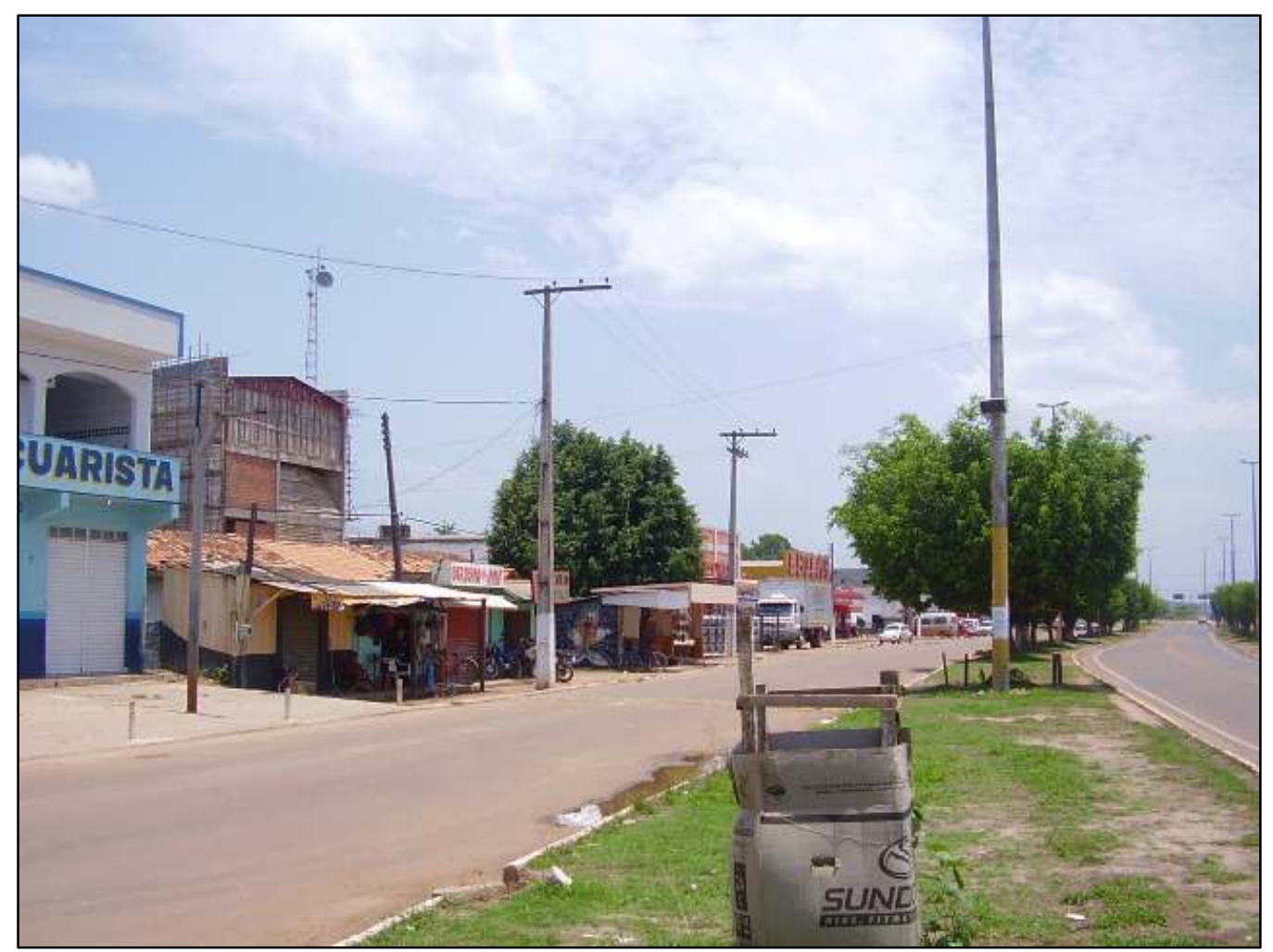

Foto 22: Avenida Central do Bairro Morada Nova

Fonte: Ribeiro, R. (Trabalho de campo/outubro de 2008)

Comentário: Avenida Central do Bairro Morada Nova, acesso às rodovias BR-222 e PA-150, eixos de interligação com os demais municípios e a capital do Estado.

$\mathrm{Na}$ conformação dessas dinâmicas socioespaciais, que deram origem a essa forma urbana polinucleada, as atividades econômicas tiveram uma importância significativa, e é, partindo desta relação, que desenvolveremos nossa análise a partir daqui, sob a ótica das atividades produtivas, especialmente àquelas voltadas para as indústrias - a indústria siderúrgica, altamente dependente das dinâmicas da globalização; a indústria da construção civil, com forte articulação regional e voltada para demandas locais; a moveleira, a frigorífica e a leiteira, que articulam as relações intra e inter-regional -, e as atividades voltadas ao comércio e os serviços, em que ambas tem contribuído para o fortalecimento de Marabá como uma cidade média, a partir dos fixos que nela se instalam, e dos fluxos que dela partem, e para ela se estabelecem. 


\section{CAPITULO II}

\section{A CIDADE MÉDIA E A SUA CENTRALIDADE URBANO-REGIONAL}

\subsection{Reestruturação urbana e cidades médias na Amazônia}

Para analisar a reestruturação urbana vivenciada pelo sudeste paraense e o papel desempenhado por Marabá, enquanto cidade média, nesse processo é importante de imediato discutir as transformações na urbanização brasileira no período mais recente.

Neste sentido, as contribuições de Santos (2005), Lencioni (2004) e Sposito (2000; 2004) são primorosas. O primeiro autor ao discutir as transformações verificadas na urbanização brasileira vai propor a passagem da simples "urbanização da população", entendida como sendo a presença de um grande percentual de pessoas vivendo nos núcleos urbanos, para "urbanização da sociedade", entendida como a presença de variáveis e nexos modernos no seio da sociedade, e para "urbanização do território", entendido como sendo a difusão do meio técnico-científico e informacional, junto com seus nexos e variáveis modernas no conjunto do território. Assim, não se trata apenas de uma mudança no plano das relações sociais, mas também de uma modernização do território. Tal como afirma Santos:

Estaríamos, agora, deixando a fase da mera urbanização da sociedade, para entrar em outra, na qual defrontamos a urbanização do território. A chamada urbanização da sociedade foi o resultado da difusão, na sociedade, de variáveis e nexos relativos à modernidade do presente, com reflexos na cidade. A urbanização do território é a difusão mais ampla no espaço das variáveis e nexos modernos (SANTOS, 2005, p.138).

Para se entender essa "urbanização do território", Santos (1994) propõe que se trabalhe com a "economia política da urbanização" e a "economia política da cidade". Enquanto a primeira leva em consideração a divisão social do trabalho que, junto com a divisão territorial do trabalho, definem a divisão dos instrumentos de trabalho, do emprego, dos homens num determinado espaço; a segunda considera a organização interna da cidade, sua forma de produzir e a inserção dos diferentes sujeitos da vida urbana se localizam a cada momento da história da cidade. Para esse autor, a economia política da urbanização e da cidade são inseparáveis e devem ser vistas articuladamente: 
A verdade é que, uma e outra, a economia política da urbanização e a economia política das cidades, são inseparáveis. Elas se distinguem de um ponto de vista analítico, mas são, de fato, inseparáveis, porque a urbanização não é apenas um fenômeno social, ou econômico, ou político, mas também é um fenômeno espacial. (...) Há, portanto, uma relação de causa e efeito recíprocos entre a cidade, como ela se organiza materialmente, e a urbanização, como ela se faz (SANTOS, 1994, p. 118).

Ainda falando das transformações na urbanização do país, Santos (2005) aponta dois fenômenos para o entendimento das metrópoles brasileiras. De um lado, aponta a "dissolução da metrópole", vista como um fenômeno que está relacionado à presença das metrópoles em todos os lugares e em todos os momentos do território brasileiro, seja como tecnoesfera (sistema de técnicas), seja como psicoesfera (sistema de valores). Conforme afirma esse autor:

Antes, a metrópole não apenas não chegava ao mesmo tempo em todos os lugares, como a descentralização era diacrônica: hoje a instantaneidade é socialmente sincrônica. Trata-se, assim, de verdadeira "dissolução da metrópole", condição, aliás, do funcionamento da sociedade econômica e da sociedade política (2005, p. 102).

O que torna possível essa dissolução da metrópole, agora, é a informação. Como indica, a metrópole na atualidade é mais informacional e menos industrial, o que se comprova pelo aumento de seu poder organizador, que vem se somar à desconcentração da atividade fabril. Neste sentido, é a informação que torna possível que São Paulo se faça presente em todos os pontos do território brasileiro ao mesmo tempo, por meio de articulações geradoras de fluxos de informações indispensáveis ao processo produtivo e a reprodução da lógica da dispersão e da concentração. Como diz Santos,

Se muitas variáveis modernas se difundem amplamente sobre o território, parte considerável de sua operação depende de outras variáveis geográficas concentradas. Dispersão e concentração dão-se, uma vez mais, de modo dialético, de modo complementar e contraditório. É desse modo que São Paulo se impõe como metrópole onipresente e, por isso mesmo, e ao mesmo tempo, como metrópole irrecusável para todo o território brasileiro (SANTOS, 2005, p.101).

De outro lado, Santos (2005) aponta a desmetropolização, que acontece junto com a metropolização. Paralelamente ao crescimento das grandes e muito grandes aglomerações, que alcançam o patamar de metrópole, têm-se também o crescimento do número cidades 
intermediárias e de suas respectivas populações, o que provoca a diminuição relativa da população dos grandes centros urbanos.

Diferente dessa proposta, Lencioni (2004) propõe um entendimento a partir da "metropolização do espaço", entendida como sendo a nova forma de conceber a relação entre metrópole e região e como um processo que implementa no espaço algumas características que durante muito tempo estiveram restritas exclusivamente aos espaços metropolitanos. Como ela diz:

O processo de metropolização do espaço imprime ao território características que no passado eram específicas da concentração metropolitana. Espaços se metropolizam e podemos distinguir: espaços metropolizados e espaços não metropolizados (LENCIONI, 2004, p. 74).

Partido da experiência do Estado de São Paulo, a autora aponta como sendo algumas das características dos espaços metropolizados, a multiplicidade, a intensidade e a permanência de fluxos de pessoas, a densidade de fluxos imateriais, a relação espaço-tempo comprimida, o distanciamento relativo e não absoluto.

Segundo Lencioni (2004) a nova forma da metrópole está relacionada às mudanças recentes pelas quais têm passado a industrialização no estado de São Paulo. Essas mudanças estão relacionadas ao processo de desconcentração territorial da indústria, que levam plantas industriais a se localizarem em diversos municípios do interior paulista, principalmente aqueles que estão nos eixos rodoviários e também os que estão localizados no entorno da metrópole. Como indica Lencioni (2003), esse movimento se refere à cisão territorial adotada pelas grandes e médias empresas que, apesar de localizarem o seu "chão de fábrica" nas cidades médias do entorno metropolitano, continuam mantendo a primazia na metrópole que continuam assumindo o controle e gestão territorial:

A expansão recente da indústria para o interior e a afirmação da primazia da metrópole de São Paulo se deram no bojo da estratégia territorial das industriais (sic) que, ao localizarem as plantas industriais no interior, causam impactos locais pelas exigências em infra-estrutura, oportunidades de trabalho que ofereceram e demais desdobramentos, tais como a complementaridade ou competição industrial induzida e o desenvolvimento do setor de comércio e serviços em muitas cidades (LENCIONI, 2003, p. 469). 
Uma terceira contribuição interessante para o entendimento do tema vem de Sposito (2004; 2007), que ao discutir o processo de modernização do território brasileiro, tomando como referência as dinâmicas econômicas, levanta a necessidade de pensar duas dinâmicas e processos distintos, porém complementares e articulados entre si: a reestruturação urbana e a reestruturação da cidade. A primeira tem como objetivo verificar as transformações profundas por que tem passado os papéis urbanos, decorrentes da redefinição da divisão interurbana do trabalho, principalmente na passagem de uma economia fordista para um regime de acumulação flexível. A segunda, está relacionada as mudanças ocorridas na estrutura dos espaços urbanos, seja na distribuição dos usos do solo para o desenvolvimento de atividades econômicas, seja na organização do habitat urbano, enfim, o enfoque busca entender as formas urbanas, mas na perspectiva da morfologia urbana que busca valorizar seus conteúdos. De uma lado, quando a autora usa o adjetivo "urbana", está fazendo referência as mutações regionais e/ou nas redes urbanas, portanto, enfatizando dinâmicas e processos de escalas de maior amplitude; de outro lado, quando usa "da cidade", está se referindo a escala intra-urbana, de maneira a revelar a forma urbana que é sempre um ponto de chegada ou de partida, portanto, relaciona-se a processos.

Ao discutir as transformações econômicas capitalistas que impactaram diretamente a rede urbana brasileira e que promoveram uma maior valorização das cidades médias, Sposito (2000) três momentos como centrais: o primeiro, que se refere ao período entre 1930-1955, em que surgiram iniciativas públicas e privadas com o intuito de estabelecer bases materiais para o desenvolvimento de uma estrutura urbano-industrial no país, que ampliou os papéis urbanos e ofereceu melhores condições infra-estruturais para circulação, o que veio possibilitar a formação de um mercado consumidor nacional e uma estruturação urbana. O segundo, desencadeado a partir de 1955 até parte dos anos 1980, em que ocorre a desconcentração de parte da produção de países de industrialização consolidada para países com a base de sua produção apoiada no setor primário. Nesse período a autora destaca o aumento significativo da produção industrial do país, o que se refletia no aumento do número de produtos disponíveis para o consumo, o que fez com que as cidades intermediárias tivessem maior importância. O terceiro, destaca o final do século XX, passagem do sistema fordista para o sistema flexível de produção que desencadeia novas dinâmicas como, a ampliação da importância das grandes metrópoles com o aumento dos papéis de gestão empresarial e financeira do capital, a descentralização da atividade produtiva 
aumentando o papel de cidades grandes e médias, com centralização de decisões, como resultado da concentração de capitais que reforçou o terciário superior das grandes metrópoles, à exemplo de São Paulo que alçou o patamar de ponto da rede global de cidades, o aumento do emprego informal e do desemprego como resultado da flexibilização dos processos produtivos, e o avanço das disparidades intra-urbanas, sobretudo nas cidades maiores, devido a elevação do custo de vida e a diminuição do mercado de trabalho.

Todas essas transformações indicadas pelos autores supracitados, fizeram com que a cidade média passasse a ter maior importância na dinâmica da rede urbana brasileira, o que impõe a necessidade de uma maior discussão sobre sua definição, seu papel e significado em termos da urbanização brasileira e amazônica, antes de falar especificamente da realidade da cidade de Marabá.

A esse respeito Sposito $(2000 ; 2004)$ afirma que é necessário, de imediato, distinguir cidade de porte médio, de cidade média. Enquanto a primeira se caracteriza por fatores relacionados ao tamanho demográfico (tamanho populacional), a segunda está relacionada ao papel desempenhado por esse nível de cidades a partir do que ela denomina de uma articulação entre os níveis interurbanos e intra-urbanos das cidades. Como afirma a autora:

Podemos admitir a existência de cidades de porte médio, em função de características que lhe é intrínseca, como seu tamanho demográfico, mas não podemos reconhecer se uma cidade de porte médio é uma cidade média, ou seja, aquela que desempenha papéis de intermediação na rede urbana, sem compreender, ao mesmo tempo, suas características (o que não se restringe ao tamanho demográfico e deve incluir a estruturação interna de seus espaços), como suas relações com outras cidades (o que impõe o reconhecimento de seus papéis na estruturação urbana da rede) (SPOSITO, 2004, P. 331)

Como ela afirma ao longo de seus argumentos, o conceito de "cidades médias" somente é adequado para "cidades de porte médio" que desempenham papéis de intermediação e/ou regionais, o que faz com que muitos autores, principalmente, os de língua espanhola, utilizem o termo "cidade intermediária".

Seguindo esse raciocínio, Trindade Jr. e Pereira (2007) ao procurarem entender a importância das cidades médias na Amazônia Oriental, recuperam essa distinção feita pela autora entre cidade de porte médio, aquela que apresenta determinado patamar populacional que ela aceita ser entre 100 mil e 500 mil habitantes; cidade média, aquela que desempenha a função de 
centro sub-regional, com capacidade de polarizar significativo número de centros menores e de articular relações de diversas ordens, especialmente em termos de anteparo e suporte às metrópoles regionais, ainda que não componha com elas unidade funcional continua e/ou contígua; e cidade intermediária, aquela que assume uma posição na hierarquia urbana entre as principais cidades regionais e as cidades locais, podendo ou não assumir importância regional.

Diante do exposto, Sposito (2004) afirma que o número de cidades de porte médio bem maior que os de cidades médias, uma vez que nem todas que possuem tamanho demográfico que justifica sua posição como uma cidade de porte médio, ocupam "situação geográfica favorável" para desempenhar funções regionais ou intermediárias. Sobre esse aspecto a autora chega mesmo a dizer que desde Christaller que se aceita que para reconhecer uma cidade média é preciso considerar dois aspectos principais: primeiro deve ser observada a posição da cidade na rede urbana; segundo, deve ser considerada sua situação geográfica, condição fundamental para definir o potencial de uma cidade vir a exercer papel de intermediação nas relações que estabelecem com outras cidades da rede urbana.

Dentre as condições que Sposito $(2000 ; 2004)$ indica para definição de cidades médias pode-se considerar as seguintes: a) a cidade não deve fazer parte de regiões megalopolitanas, metropolitanas e aglomerações, pois isto compromete o aspecto de intermediação, devido seu alto nível de integração ou coesão à essa área urbana estruturada funcionalmente; b) a distância maior ou menor em relação as cidades de maior porte, o que fazer com que ela acabe assumindo um papel de maior centralidade em relação ao oferecimento de bens e serviços à sociedade; c) o papel intermediário de uma cidade deve-se às suas relações com centros urbanos maiores, menores e do seu patamar, bem como com o espaços rurais com quem mantém uma vida de relações.

Ainda com base na realidade urbana brasileira, queremos destacar dois autores de suma importância para o entendimento dessa temática das cidades médias, são eles, Santos e Silveira (2001) e Silveira (2002). Do primeiro trabalho realizado conjuntamente pelos autores deve-se destacar que as cidades médias no Brasil têm assumido um papel mais técnico do que político, desse modo, politicamente falando acabam por ficar subordinadas às metrópoles nacionais ou estrangeiras. Em seus termos,

(...) as cidades médias têm como papel o suprimento imediato e próximo da informação requerida pelas atividades agrícolas e desse modo constituem em 
intérpretes da técnica e do mundo. Em muitos casos a atividade urbana acaba sendo claramente especializada, graças às suas relações próximas e necessárias com a produção regional (SANTOS; SILVEIRA, 2001, p. 281).

Dentre os papéis que essas cidades médias estão assumindo na reprodução da dinâmica capitalista no território brasileiro estão, o consumo consumptivo e o consumo produtivo. $\mathrm{O}$ primeiro refere-se a oferta de meios de consumo final das famílias (educação, saúde, lazer, religião, informação) e das administrações (associado ao exercício da cidadania). O segundo diz respeito, entre outras coisas, ao consumo intermediário das empresas, a produção de bens e serviços exigidos por elas próprias e por seu entorno.

Um aspecto novo que já se observa nessa primeira discussão dos autores é o início do rompimento daquela leitura que coloca a cidade média numa posição intermediária entre a metrópole e as cidades pequenas. Silveira (2002), por sua vez, vai levar essa discussão mais adiante, quando, ao analisar as cidades médias diante da globalização considera ser necessário repensar os conteúdos assumidos pelos novos meios geográficos contemporâneos e estruturar um esquema interpretativo que permita abordá-la a partir de sua especificidade. Dessa feita, aponta que a cidade não deve ser entendida em si mesma, sendo preciso analisá-la incluída no movimento da totalidade ou da totalização, de maneira a descobrir as lógicas contraditórias existentes no território, que é produzido por objetos e ações.

É a divisão territorial do trabalho, produto e condição da divisão social do trabalho, que se identifica nas cidades, no território nacional e no mundo. As redes urbanas, sendo arcabouço desse sistema de trabalho, outorgam papéis e valores diversos às metrópoles, às cidades regionais, às cidades locais (SILVEIRA, 2002, p. 12).

Na sua interpretação, Silveira (2002) propõe que as cidades médias devem ser vistas como nós de uma divisão do trabalho mundializada, e o estudo de suas especializações pode ser um caminho para entender a recente organização do espaço. De modo que aponta para o fato das cidades médias serem chamadas a desempenhar a cada dia mais um comando técnico da produção, perdendo, por outro lado, a possibilidade de assumir um comando político.

Ao lado dessa dimensão mais vertical das cidades médias, Silveira (2002) apresenta à necessidade de se considerar a dimensão da horizontalidade, formado pelo trabalho local, pela porosidade do modelo e pela contigüidade do território. Buscando avançar ainda mais nas discussões propostas por Milton Santos a respeito do circuito inferior da economia urbana, 
mostra que essas atividades complementares acabam se instalando em lugares especializados, tais como, terminais e ruas comerciais, e defende levanta a hipótese de que mais do que o lócus da reprodução econômica, o território é o lugar do trabalho e da vida.

Considerados imóveis porque estão privados de fluidez e velocidade, estes agentes terminam por defender o uso de um território que é, ao mesmo tempo, o do trabalho e o da vida. Não há aqui telecomando, nem separação material das instâncias de produção e circulação. É um circuito criador de trabalho e visto como marginal (SILVEIRA, 2002, p. 15).

Tomando como referência a realidade amazônica queremos destacar a contribuição teórica oferecida por Oliveira (2008) para essa discussão sobre cidades médias. Esse autor inicia sua discussão apontando para as limitações de se analisar a rede urbana apenas por critérios demográficos, considerando ser necessário relacionar esses critérios demográficos tradicionais com a compreensão da oferta de serviços e infra-estrutura, no sentido de evidenciar as diferenças entre as cidades, tanto na relação que estabelecem entre si, quanto nas relações com as redes urbanas regionais, nacionais e internacionais. Dessa forma, a definição de uma cidade como pequena ou média não é uma questão demográfica, mas relacional, de sua atuação na estruturação da rede urbana da região.

Ao se estabelecer uma tipificação das cidades da calha do Rio Solimões-Amazonas, Oliveira (2008) procura considerar os limites de uma aproximação entre a realidade e a teoria usada para análise. A tipologia e o desenho da rede urbana proposta neste estudo possibilita a análise das relações socioespaciais constituídas no território e a compreensão das mudanças e permanências pelas quais passaram as cidades nessa parte do Brasil tão importante por sua bio e sociodiversidade. De um lado, existem cidades que devem ser entendidas na relação que estabelecem com o processo de mundialização, portanto, a partir da relação local e global; de outro lado, existem cidades que devem ser entendidas fora dessa relação, com base em outras lógicas e outros valores (reservas territoriais para outro modo de vida).

Por fim, Oliveira aponta a seguinte tipologia das cidades médias no Amazonas: a) cidade média de responsabilidade social (Tefé, Manacapuru, Parintins e Itacoatiara) - possui nodos importantes para rede; contem arranjos institucionais importantes para si e para os municípios ao seu redor; b) cidade média com dinâmica econômica externa (Coari) - possui relações verticais densas e relações fracas com as demais cidades da região, uma vez que pouco agrega valor no 
local; c) cidade média de fronteira (Tabatinga) - possui rede difusa, além da calha e com países vizinhos, destacando-se o papel das forças armadas em sua dinamização.

Por mais que a contribuição de Oliveira (2008) seja a mais interessante em termos de proposição teórica para pensar o tema das cidades médias a partir da realidade amazônica, devese considerar os estudos realizados por Ribeiro (2001), Pereira (2004), Trindade Jr. (2005) e Trindade Jr. e Pereira (2007).

Ribeiro (2001) ao analisar as transformações na rede urbana regional levanta a hipótese de que a rede urbana da Amazônia desde os anos de 1960 até os de 1990 vem passando por diversas transformações que se manifestam na passagem de uma rede urbana de estrutura simples ou dendrítica a uma rede urbana complexa ou de múltiplos circuitos. Essa complexidade está relacionada ao fato de que cada centro urbano desempenha múltiplos papéis, vinculando-se, de modo diferenciado e simultaneamente, a diversas redes.

Considerando esse aspecto, a pesquisa de Ribeiro (2000) identificou além dos quatro centros regionais, que combinam mais de 100 interações no que se refere à procura de funções centrais (produção, distribuição e gestão) e perfazem um total de 250 relacionamentos, quinze cidades que atuam como centros sub-regionais, na nossa pesquisa definidas como cidades médias, e que se constituem em importantes centros de distribuição de bens e serviços: Imperatriz, Araguaína, Bacabal, Gurupi, Porto Velho, Rio Branco, Rondonópolis, Ji-Paraná, Caxias, Santa Inês, Várzea Grande, Vilhena, Marabá, Santarém e Castanhal.

Também o trabalho de Trindade Jr. (2005) apesar de não ter a preocupação central de pensar a cidade média, uma vez que tinha como objetivo discutir a relação entre os grandes projetos econômicos, a difusão da urbanização do território e o processo de metropolização na Amazônia, tendo em vista a inserção de Belém na dinâmica da rede urbana regional, acaba apontado elementos interessantes a respeito da inserção das cidades médias na rede urbana regional.

De início esse autor aponta que o processo de metropolização de Belém e a configuração atual da rede urbana regional somente podem ser entendidos se considerarmos a forma como se deu à inserção do capitalismo dentro da Amazônia nos anos mais recentes, a chamada fronteira econômica e urbana. Dessa forma, verifica-se que diferentemente da Amazônia ocidental, onde população, urbanização e atividades econômicas encontram-se concentradas na metrópole (Manaus) - por mais que esta visão seja questionada por Oliveira (2008) - na Amazônia oriental 
essas dinâmicas apresentam-se mais dispersas pelo território, principalmente, nas áreas dos grandes projetos econômicos, o que oferece maior importância às cidades médias que cada vez mais apresentam dimensões maiores, acompanhando a tendência verificada no país, ainda que continuem apresentando o mesmo grau de precariedade da qualidade de vida presentes nas grandes cidades, diferente daquilo que se vislumbra para as cidades médias brasileiras, símbolos de qualidade de vida, de empregos qualificados e riqueza. Ressaltando, para o autor esse dinamismo das cidades médias amazônicas e também das chamadas company towns relaciona-se à presença de grandes empreendimentos econômicos dispersos pelo território, principalmente, os grandes projetos. Estes acabaram sendo fundamentais para dinamização da urbanização do território na região, pois para poderem desenvolver suas atividades precisaram modernizar alguns espaços urbanos regionais com infra-estrutura que contribuíram para criar externalidades fora do aglomerado metropolitano de Belém. Assim, esses espaços que abrigam grandes empreendimentos econômicos - Parauapebas, Barcarena, Tucuruí, Oriximiná, Almerim - passam a ser nexos importantes na modernização da urbana da região, tornam-se espaços difusores do meio técnico-científico e informacional.

Pereira (2004) ao discutir a importância e o significado das cidades médias na Amazônia a partir da realidade de Santarém, localizado no Oeste do Estado do Pará, aponta algumas considerações importantes que nos ajuda a pensar também a realidade de Marabá: a) Santarém é um pólo regional na realidade em que se insere, pois tem se voltado ao atendimento das necessidades da população, tanto da própria cidade, quanto das cidades próximas, o que lhe confere um significativo nível de centralidade na mesorregião do Baixo Amazonas; b) a cidade tem servido como mediação entre as pequenas e grandes centros da região, principalmente, Manaus e Belém, com quem mantém fortes relações; c) a cidade tem grande importância política para o Baixo Amazonas, pois desempenha o papel de fórum de decisões e debates sobre a região. Esse aspecto é fundamental para se pensar as cidades médias na Amazônia, pois nos estudos até agora realizados tem se revelado como um aspecto particular da Amazônia; c) a cidade é o grande centro de crescimento econômico dentro da sua região, tendo como principais atividades produtivas o setor de comércio e prestação de serviços; d) Santarém apresenta capacidade no que tange ao recebimento e a fixação de migrantes provenientes de cidades menores ou mesmo da zona rural, mostrando, no entanto, fragilidade quanto à oportunidade de empregos; e) a cidade, apesar de desempenhar o papel de sub-centro regional e de apresentar população superior a 100 
mil habitantes, o que a torna também uma cidade de porte médio, tem dificuldades de comunicação com o restante do Estado do Pará, devido em grande medida a precariedade dos meios de circulação (rodovias sem asfaltamento - Transamazônica e Cuiabá-Santarém - e distância elevada para o transporte fluvial - o tempo gasto entre Belém e Santarém é muito grande) e de informação (baixo percentual de residências com telefone instalados, com computadores ou Internet); f) Santarém possui uma situação "geográfica" favorável, ou seja, dispõe de recursos naturais e terras abundantes, rios navegáveis e estradas Sétima e última consideração, a experiência de Santarém mostra que as cidades médias da Amazônia reproduzem as mesmas condições de pobreza e desemprego presente na metrópole. Ao comparar Santarém com cidades médias de São Paulo (Marília, Presidente Prudente, Sorocaba e Franca), mostra que as últimas apresentam melhores desempenhos quanto aos indicadores de renda e pobreza urbana, emprego, educação, acesso aos serviços de saneamento e oferta de bens e serviços (PEREIRA, 2004).

Em artigo sobre a reestruturação da rede urbana Amazônica e a importância assumida pelas cidades médias, Trindade Jr. e Pereira (2007), buscam centrar sua análise na compreensão da estrutura urbana regional, tendo em vista o destaque assumido pelas cidades médias no processo de produção do espaço regional. Neste sentido, tendo como referência empírica de pesquisa as cidades de Marabá, Santarém e Castanhal, os autores apontam, conforme já demonstramos no primeiro capítulo deste trabalho, que as cidades médias para além do patamar populacional, são aquelas que se constituem como espaço de mediação entre as pequenas cidades e os grandes centros, mediação esta realizada em várias dimensões e sentidos de modo a garantir um papel regional. Do ponto de vista dos fluxos as três cidades em questão servem de referência para outras cidades dentro da mesorregião em que se inserem ou com quem se articulam; Da perspectiva política, indicam que apenas Santarém e Marabá assumem esse papel de mediação, uma vez que tem se constituído como espaços privilegiados de discussão em torno de questões que tem afetado suas regiões. Já Castanhal, diferentemente das outras duas cidades, não tem esse peso político uma vez que acabam reforçando, na maioria das vezes, os blocos políticos sediados na capital do estado. Quanto ao aspecto econômico, os autores afirmam que essas cidades têm se destacado no âmbito regional devido ao significativo crescimento que tem apresentado, conforme se pode verificar, dentre outros, na sua arrecadação do ICMS (Imposto sobre Circulação de Mercadoria e Serviços) e do IPI (Imposto sobre Produtos Industrializados). Além desses 
aspectos, os autores destacam ainda dois elementos importantes para se analisar as cidades médias na Amazônia: a primeira delas refere-se à capacidade de receber e de fixar migrantes provenientes de cidades menores e da própria zona rural, por mais que apresentem fragilidade quanto às oportunidades de trabalho; a segunda, diz respeito à baixa qualidade de vida dessas cidades, que diferentes daquelas do centro-sul do país, vêm acompanhando as mesmas condições de precariedade e pobreza das metrópoles. Como afirmam esses autores:

\begin{abstract}
Dessas três cidades, Santarém e Marabá assumem indubitavelmente a condição de cidades médias por várias razões. Têm importante papel na oferta e distribuição de bens e serviços para sua população e para as cidades menores de seu entorno, especialmente para as sub-regiões nas quais se inserem ou com que se articulam diretamente - Sudeste Paraense (Marabá) e Baixo Amazonas e Sudoeste Paraense (Santarém). Desempenham importante liderança política formando opinião e polarizando os debates acerca das estratégias e diretrizes nas mesorregiões anteriormente referidas. Pelo fato de não estarem inseridas no espaço metropolitano de Belém (...) e guardarem certa distância da capital, acabam por desempenhar uma dinâmica econômica, política e cultural relativamente autônoma (TRINDADE JR; PEREIRA, 2007, p. 337-338)
\end{abstract}

Para terminar essa parte do trabalho resta ainda discutirmos o artigo elaborado por Trindade Jr e Ribeiro (2009) sobre cidades médias, mas tomando como referência empírica de pesquisa a cidade de Marabá. Neste trabalho, os autores têm como objetivo central compreender a importância assumida por essas cidades na estrutura urbana regional amazônica tendo em vista a centralidade exercida pela cidade de Marabá no sudeste paraense.

Partindo dessa preocupação central, os autores procuram entender como no processo de reestruturação produtiva da rede urbana amazônica, a cidade de Marabá foi assumindo esse papel de relevância regional. Dessa forma, procura-se adensar as reflexões teóricas a respeito desse patamar de cidades no Brasil, enfatizando a especificidade regional amazônica, bem como ampliar e complementar conhecimentos e discussões que já vêm sendo realizados sobre esse nível de cidade em diferentes regiões brasileiras.

Os autores procuram sustentar que, em que pese à centralidade regional assumida por Marabá na dinâmica dos fluxos, verificadas por seu papel central nos novos vetores do crescimento econômico e demográfico, no fato de ser referência para vários municípios das micro e mesorregiões em que se insere, no fato de ser o "nó" de importantes redes de circulação regional, e no percentual relativamente expressivo de repasses governamentais que recebe; isto não tem se manifestado em sua estrutura interna, em sua centralidade intra-urbana. Em outros 
termos, podemos dizer que Marabá apresenta uma modernização que se manifesta muito mais por fluxos do que por fixos, pois, não obstante apresentarem alto grau de centralidade urbanoregional, a estrutura interna da cidade permanece precária, principalmente, quando comparada a esse perfil de cidades do centro-sul do país. Nas suas palavras,

Essa parece ser uma especificidade das cidades médias na Amazônia, que passam a ter mais importância na rede urbana regional das últimas décadas. Muito mais que definir um perfil de cidade moderna e que tende a configurar melhores qualidades de vida, tratam-se de espaços com importante centralidade, mas que pouco revelam uma possível incorporação das horizontalidades decorrentes dos investimentos realizados no contexto regional em que se inserem.

Essa constatação nos induz a pensar, de fato, o que seja a cidade média na região, a nosso ver, menos marcada pela presença de fixos modernos, que pela presença de fluxos de mesma ordem, responsáveis por garantir as verticalidades das relações que dão um novo sentido aos subespaços regionais em contextos de expansão de fronteiras econômicas ou tecno-ecológicas (BECKER, 2004).

Por fim, devemos ressaltar que o fato de Marabá exercer um papel de centralidade na dinâmica regional e, de isto não se refletir em sua estrutura intra-urbana, demonstra, na verdade, o papel subordinado que a região, de modo geral, e a cidade de Marabá em especial, tem assumido na lógica de expansão e reprodução capitalista. Em outras palavras, a cidade está voltada para uma lógica exterior a ela, para responder a uma demanda de capitais extra-nacionais e cumprir, como tratava Santos (2005), seu papel de "região do fazer", na divisão territorial do trabalho.

$\mathrm{Na}$ próxima parte do trabalho, procuramos mostrar como a centralidade regional de Marabá é exercida na região sudeste do Pará por meio da indústria, tanto aquela referente a dinâmicas mais verticais, como a indústria siderúrgica, quanto aquela mais articulada com o plano das horizontalidades, tais como a indústria leiteira, moveleira e da construção civil.

\subsection{Marabá: dinâmica regional e sua área de influência direta}




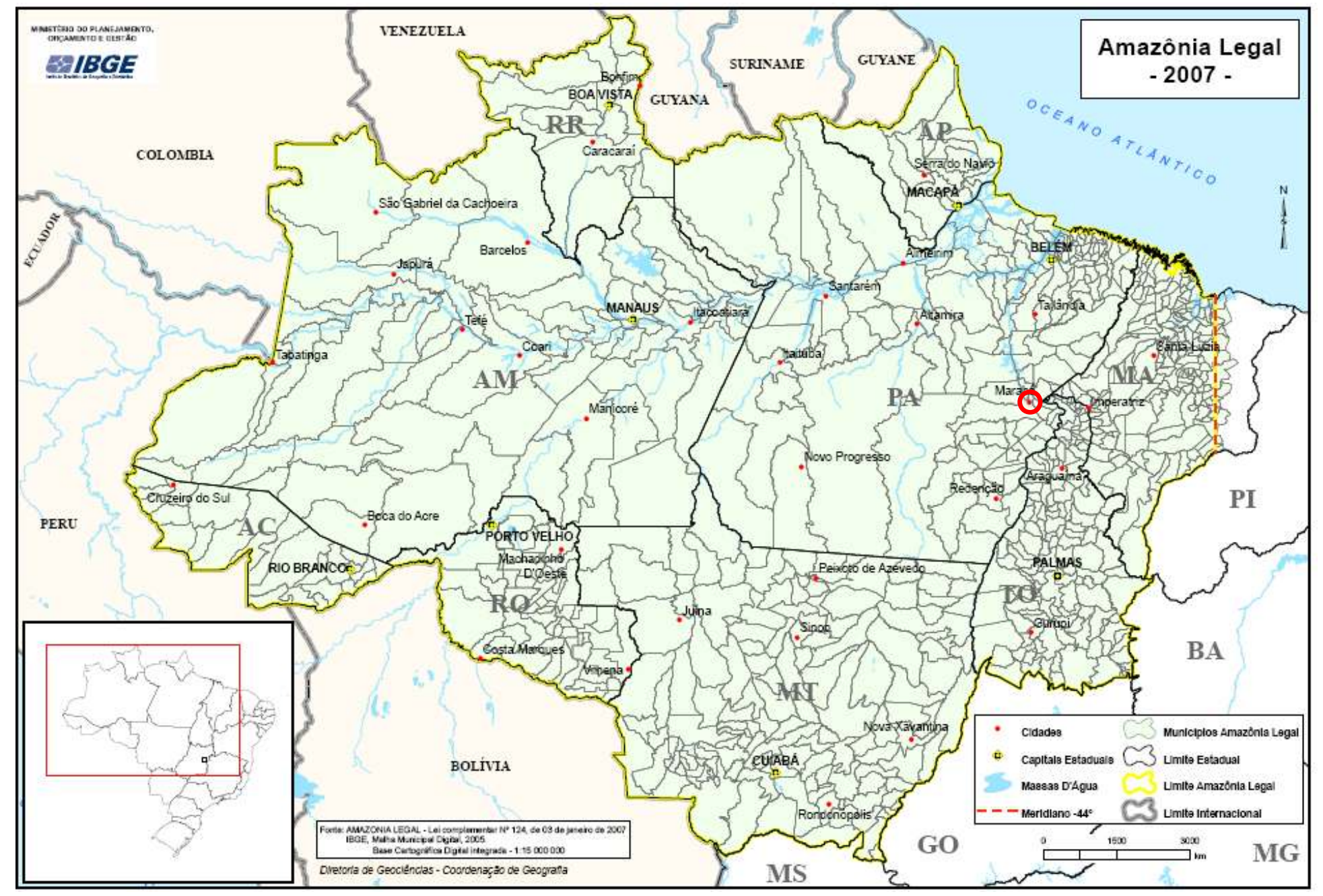

Mapa 7: Localização do Município de Marabá

Fonte: http://www.ibge.gov.br/mapas_ibge/ 


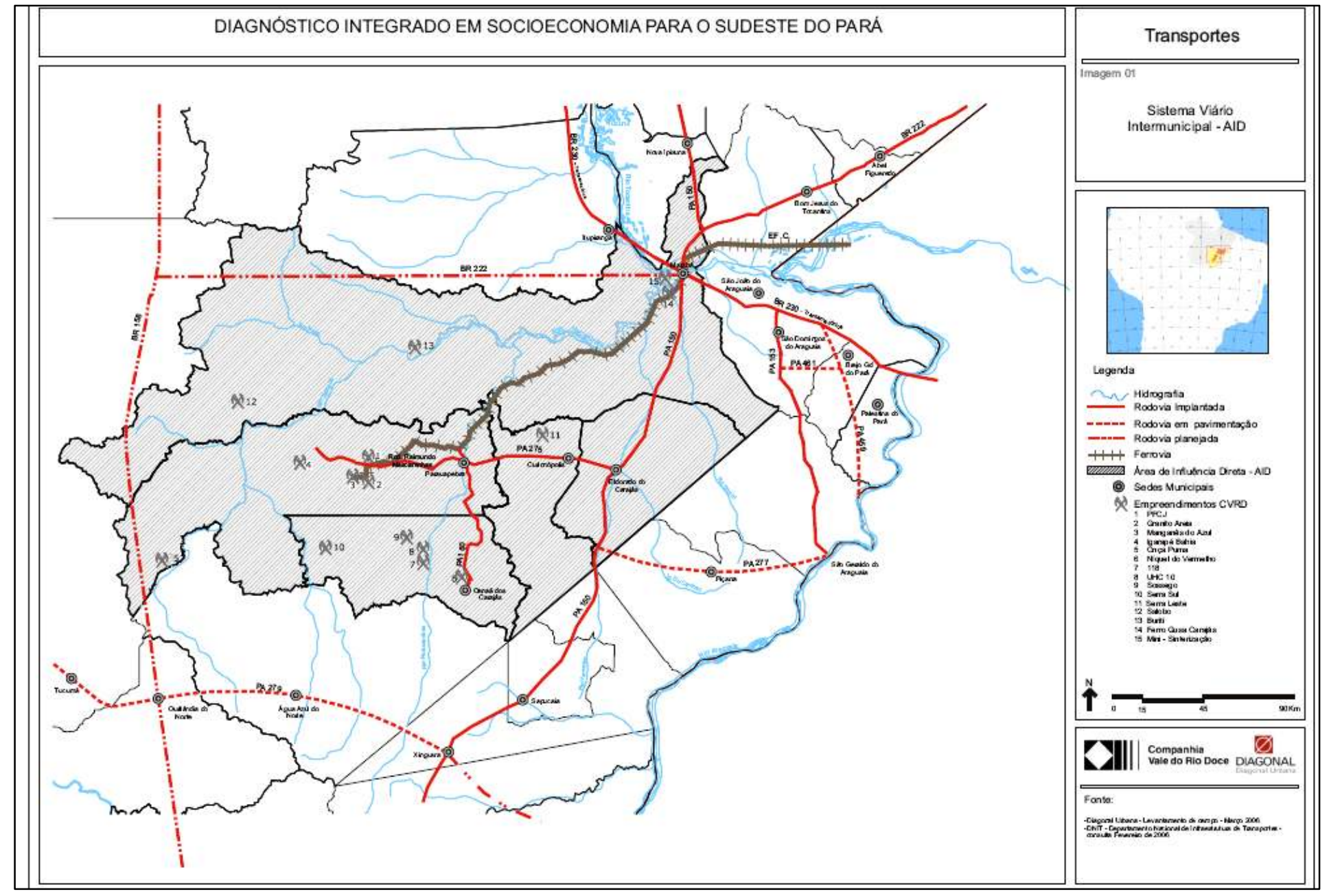

Mapa 8: Vias de circulação no sudeste paraense e a centralidade geográfica da cidade de Marabá

Fonte: COMPANHIA VALE DO RIO DOCE. Diagonal Urbana. Diagnóstico integrado em socioeconomia para o sudeste do Pará. Belém, 2007. 
Conforme se pode visualizar no mapa 7, Marabá está situada na porção oriental da Amazônia Legal e na porção sudeste do Estado do Pará. Sua localização é um ponto geograficamente estratégico no que concerne às vias de circulação do sudeste paraense, dando ao município um caráter de centralidade nesta região. Na tabela a seguir têm-se as distâncias físicas das principais cidades com as quais Marabá estabelece relações diretas, sendo estas dos Estados do Pará, Tocantins, Maranhão e Goiás.

\begin{tabular}{|c|c|c|c|c|c|}
\hline Cidade / Localidade & $\begin{array}{c}\text { Rodovi } \\
\text { a de } \\
\text { Acesso }\end{array}$ & $\begin{array}{l}\text { Distância } \\
\text { (km) }\end{array}$ & $\begin{array}{l}\text { Cidade / } \\
\text { Localidade }\end{array}$ & $\begin{array}{l}\text { Rodovia de } \\
\text { Acesso }\end{array}$ & $\begin{array}{c}\text { Distânci } \\
\text { a (km) }\end{array}$ \\
\hline Belém (PA) & PA-150 & 475 & Açailândia (MA) & BR-222/010 & 301 \\
\hline Belém (PA) & $\begin{array}{c}\text { BR- } \\
222 / 010\end{array}$ & 673 & Dom Eliseu (PA) & BR-222 & 226 \\
\hline Goianésia (PA) & PA-150 & 177 & Paragominas (PA) & BR-222/010 & 367 \\
\hline Jacundá (PA) & PA-150 & 102 & $\begin{array}{c}\text { São João do } \\
\text { Araguaia (PA) }\end{array}$ & $\begin{array}{c}\text { BR- } \\
\text { 230/Ramal }\end{array}$ & 57 \\
\hline Nova Ipixuna (PA) & PA-150 & 46 & $\begin{array}{l}\text { São Domingos do } \\
\text { Araguaia (PA) }\end{array}$ & $\begin{array}{c}\text { BR- } \\
\text { 230/Ramal }\end{array}$ & 46 \\
\hline Eldorado (PA) & PA-150 & 99 & - & - & - \\
\hline Xinguara (PA) & PA-150 & 229 & - & - & - \\
\hline Redenção (PA) & PA-150 & 341 & Araguaína (TO) & BR-222 & 234 \\
\hline $\begin{array}{c}\text { Conceição Araguaia } \\
\text { (PA) }\end{array}$ & $\begin{array}{c}\text { PA- } \\
150 / 287\end{array}$ & 440 & - & - & - \\
\hline Parauapebas (PA) & $\begin{array}{c}\text { PA- } \\
150 / 275\end{array}$ & 189 & Brasília (DF) & $\begin{array}{c}\text { BR- } \\
222 / 010 / 153\end{array}$ & 1.637 \\
\hline Serra dos Carajás (PA) & $\begin{array}{c}\text { PA- } \\
150 / 275\end{array}$ & 206 & Imperatriz (MA) & BR-222/010 & 369 \\
\hline Itupiranga (PA) & BR-230 & 45 & - & - & - \\
\hline Tucuruí (PA) & BR-230 & 228 & - & - & - \\
\hline Tucuruí (PA) & $\begin{array}{l}\text { PA-150 } \\
\text { Ramal }\end{array}$ & 256 & - & - & - \\
\hline Altamira (PA) & BR-230 & 473 & - & - & - \\
\hline
\end{tabular}

Tabela 1: Distâncias rodoviárias entre Marabá e as principais cidades dentro de sua rede de fluxos Fonte: Prefeitura de Marabá. Diagnóstico do Plano Diretor do Município de Marabá. 2006.

No que se refere à dinâmica econômica regional, o sudeste paraense contribui com 29\%, na participação do Estado, estando atrás apenas da região metropolitana de Belém, conforme podemos observar no gráfico 1. 


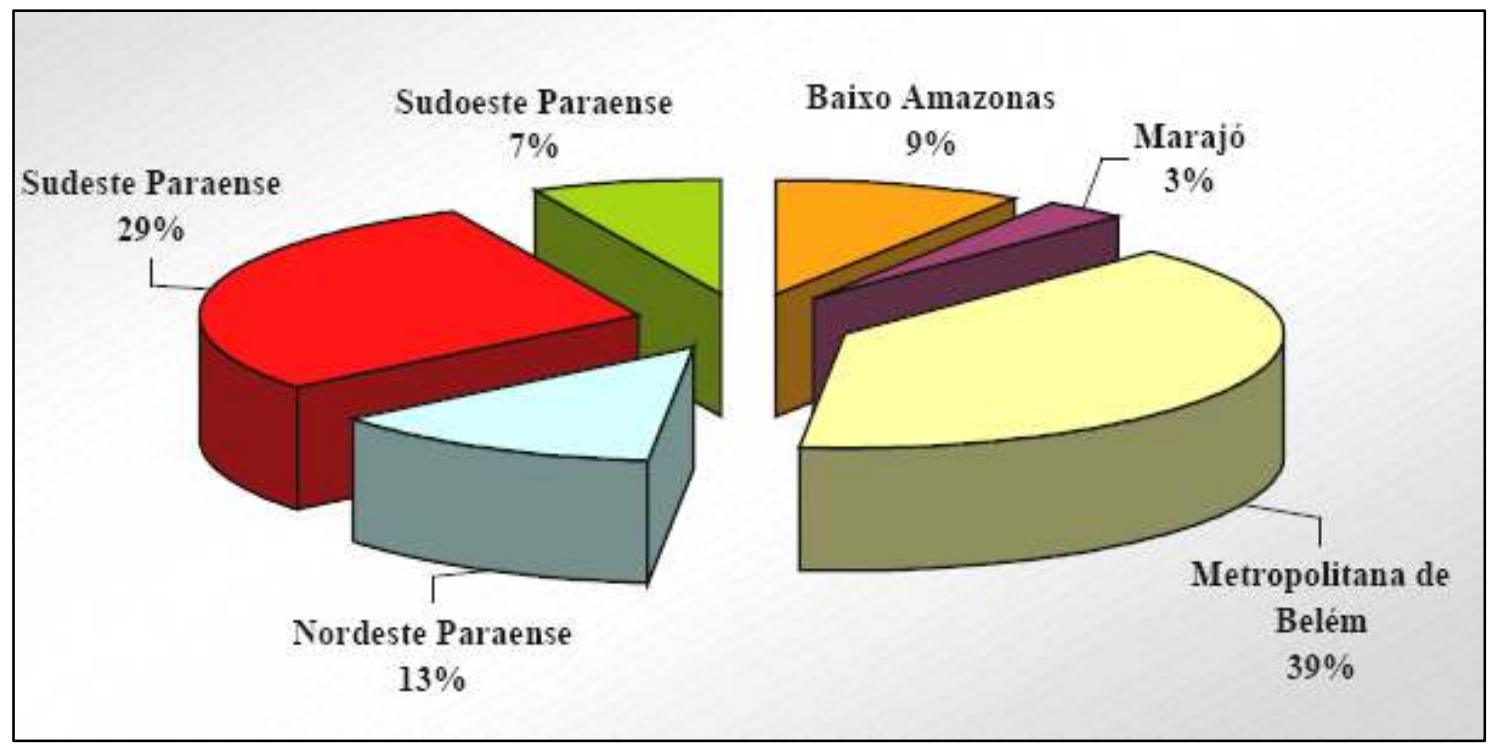

Gráfico 1: Participação das Mesorregiões no PIB do Estado do Pará Fonte: GOVERNO DO PARÁ/SEPOF, 2005.

Olhando-se pontualmente o município de Marabá no gráfico a seguir, nota-se que apresenta o sexto maior PIB do Estado do Pará de acordo com o ranking do governo estadual, estando abaixo dos municípios de Belém e Ananindeua situados na região metropolitana, Tucuruí e Parauapebas no sudeste paraense região na qual também se insere Marabá, entretanto para os dois últimos casos, deve-se notar que ambos fazem parte de grandes projetos mínero-metalúrgicos, o primeiro com o Projeto Ferro Carajás e o segundo com a Usina Hidrelétrica de Tucuruí, que contribuem para um aumento significativo do PIB municipal em função do repasse de royaltes para as prefeituras, o que leva a certa distorção da situação real da arrecadação destes municípios. 


\section{Produto Interno Bruto dos Municipios do Estado do Pará - 2005}

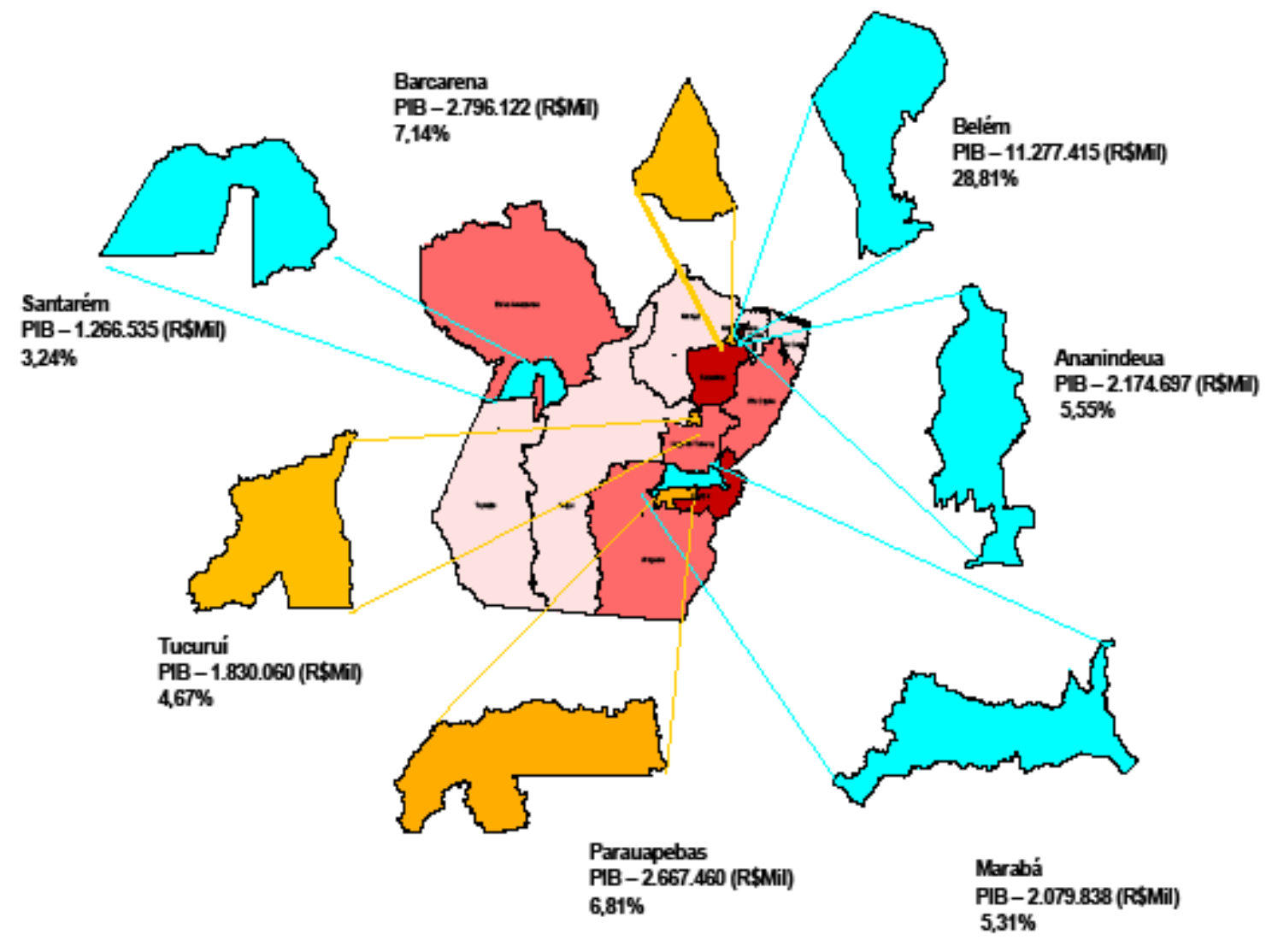

Gráfico 2: PIB do Estado do Pará - 7 maiores Fonte: GOVERNO DO PARÁ/ SEPOF, 2005.

Para o caso de Marabá o PIB concentra-se no setor de serviços e na indústria, mais especificamente na indústria siderúrgica ${ }^{14}$, conforme quadro a seguir.

\footnotetext{
${ }^{14}$ O parque industrial de Marabá no setor siderúrgico possui 11 indústrias sendo elas: Companhia Siderúrgica do Pará, D’ Terra Siderúrgica Ltda, Ferro Gusa Carajás, Ibérica Siderúrgica do Pará S/A, Marabá Gusa Siderúrgica Ltda - MARAGUSA, Sidenorte Siderurgia Ltda, Siderúrgica do Pará S/A - SIDEPAR, SINOBRAS Siderurgica Norte Brasil S. A, Terra Norte Metais Ltda, Usimar LTDA, Mineração Buritirama.
} 


\begin{tabular}{|c|c|c|c|c|}
\hline \multirow[b]{2}{*}{ Ranking } & \multicolumn{3}{|c|}{ Valor Adicionado } & \multirow[b]{2}{*}{ PIB } \\
\hline & Agropecuária & Indústria & Serviços & \\
\hline $1^{\mathrm{o}}$ & $\begin{array}{c}\text { São Félix do } \\
\text { Xingu }\end{array}$ & Belém & Belém & Belém \\
\hline $2^{\circ}$ & Medicilândia & Barcarena & Ananindeua & Barcarena \\
\hline $3^{\circ}$ & Paragominas & Tucuruí & Marabá & Ananindeua \\
\hline $4^{\circ}$ & Uruará & Parauapebas & Santarém & Tucuruí \\
\hline $5^{\circ}$ & Altamira & Ananindeua & Barcarena & Parauapebas \\
\hline $6^{\circ}$ & Santarém & Almeirim & Castanhal & Marabá \\
\hline $7^{\circ}$ & $\begin{array}{l}\text { Água Azul do } \\
\text { Norte }\end{array}$ & Oriximiná & Parauapebas & Santarém \\
\hline $8^{\circ}$ & Tucumã & Marabá & Tucuruí & Almeirim \\
\hline $9^{\circ}$ & Redenção & Redenção & Itaituba & Oriximiná \\
\hline $10^{\circ}$ & Dom Eliseu & Santarém & Paragominas & $\begin{array}{c}\text { São Félix do } \\
\text { Xingu }\end{array}$ \\
\hline
\end{tabular}

Quadro 2: Ranking do PIB dos municípios segundo setores de atividade econômica - Pará, 2002

Fonte: GOVERNO DO PARÁ/SEPOF, 2005.

No setor de serviços há presença de três centros de ensino públicos (Universidade Federal do Pará(UFPA), Universidade do Estado do Pará (UEPA) e o Centro Federal de Educação Tecnológica-PA (CEFET)), com cursos de educação superior e de pós-graduação, cursos de formação técnica, conforme quadro abaixo. 


\begin{tabular}{|c|c|c|c|}
\hline Instituição & $\begin{array}{l}\text { Cursos de } \\
\text { Graduação }\end{array}$ & $\begin{array}{l}\text { Cursos de Pós- } \\
\text { Graduação }\end{array}$ & $\begin{array}{c}\text { Cursos de Formação } \\
\text { Técnica }\end{array}$ \\
\hline $\begin{array}{l}\text { Universidade Federal } \\
\text { do Pará (UFPA) }\end{array}$ & $\begin{array}{l}\text { - Ciências Sociais } \\
\text {-Direito } \\
\text { - Licenciatura em } \\
\text { Letras (Habilitação } \\
\text { em Língua } \\
\text { Portuguesa) } \\
\text { - Licenciatura em } \\
\text { Pedagogia } \\
\text { - Licenciatura em } \\
\text { Matemática } \\
\text { - Sistemas de } \\
\text { Informação } \\
\text { - Engenharia de } \\
\text { Minas e Meio } \\
\text { Ambiente } \\
\text { - Engenharia de } \\
\text { Materiais } \\
\text { - Geologia } \\
\text {-Agronomia } \\
\text { - Ciências Naturais - } \\
\text { Química }\end{array}$ & $\begin{array}{l}\text { - Especialização em } \\
\text { Língua Portuguesa } \\
\text { - Especialização em } \\
\text { Educação Matemática } \\
\text { - Especialização em } \\
\text { Tecnologia Mineral e } \\
\text { Metalurgia } \\
\text { - Especialização em } \\
\text { Tecnologia, } \\
\text { Linguagem e } \\
\text { Educação Inclusiva } \\
\text { - História da } \\
\text { Amazônia } \\
\text { - Engenharia e } \\
\text { Segurança no trabalho }\end{array}$ & \\
\hline $\begin{array}{l}\text { Universidade Estadual } \\
\text { do Pará (UEPA) }\end{array}$ & $\begin{array}{l}\text { - Enfermagem } \\
\text { - Educação } \\
\text { Física } \\
\text {-Formação de } \\
\text { Professores } \\
\text {-Educação } \\
\text { Física } \\
\text {-Ciências } \\
\text { Naturais - Tecnologia } \\
\text { Agroindustrial } \\
\text { - Engenharia } \\
\text { Ambiental }\end{array}$ & $\begin{array}{lr}\text { - Especialização em } \\
\text { Epidemiologia } \\
\text {-Esp. em Psicologia } \\
\text { Educacional com } \\
\text { Ênfase } & \text { em } \\
\text { Psicopedagogia } & \\
\text { Preventiva } & \\
-\quad \text { Educação } & \text { Física } \\
\text { Escolar } & \\
\text { - Gestão Escolar } & \end{array}$ & \\
\hline $\begin{array}{ll}\text { Centro Federal } & \text { de } \\
\text { Educação } & \\
\text { Tecnológica-PA } & \\
\text { (CEFET) } & \end{array}$ & & & $\begin{array}{l}\text { - Informática } \\
\text { - Edificações } \\
\text { - Agrimensura }\end{array}$ \\
\hline
\end{tabular}

Quadro 3: Instituições de ensino superior e de formação técnica e seus respectivos cursos no Município de Marabá

Fonte: Universidade Federal do Pará (UFPA), Universidade Estadual do Pará (UEPA), Centro Federal de Educação Tecnológica-PA (CEFET), 2008.

Elaboração: Ribeiro, R. 2009. 
Ainda referente a este setor, em função de seu papel de confluência de eixos de circulação, Marabá apresenta um razoável movimento de rotas aéreas nacionais e internacionais, embora ainda pequeno em relação a outras cidades médias brasileiras, conforme demonstram os estudos de Sposito (2007), mais importantes do ponto de vista da dinâmica regional, tal como se pode observar na tabela subseqüente.

\begin{tabular}{|c|c|c|c|c|c|c|c|c|c|}
\hline & \multicolumn{3}{|c|}{ Aeronaves (unid.) } & \multicolumn{3}{c|}{ Passageiros (unid.) } & \multicolumn{3}{c|}{ Carga Aérea (Kg) } \\
\cline { 2 - 11 } Anos & Doméstico & $\begin{array}{c}\text { Interna } \\
\text { Cional }\end{array}$ & Total & Doméstico & $\begin{array}{c}\text { Interna } \\
\text { cional }\end{array}$ & Total & Doméstico & $\begin{array}{c}\text { Interna } \\
\text { cional }\end{array}$ & Total \\
\hline 2003 & 6.001 & 16 & 6.017 & 73.838 & 0 & 73.838 & 1.566 .196 & 0 & 1.566 .196 \\
\hline 2004 & 5.539 & 18 & 5.557 & 78.267 & 5 & 78.272 & 1.700 .038 & 0 & 1.700 .038 \\
\hline 2005 & 5.817 & 10 & 5.827 & 87.151 & 2 & 87.153 & 1.474 .846 & 0 & 1.474 .846 \\
\hline 2006 & 6.499 & 14 & 6.513 & 90.210 & 23 & 90.233 & 1.302 .954 & 190 & 1.303 .144 \\
\hline 2007 & 8.874 & 25 & 8.899 & 188.261 & 10 & 188.271 & 1.642 .913 & 205 & 1.643 .118 \\
\hline
\end{tabular}

Tabela 2: Movimento Operacional Acumulado do Aeroporto de Marabá (SBMA) - REDE INFRAERO (Janeiro a Dezembro de 2004 a 2007)

Fonte: Infraero, 2008.

Organização: Ribeiro, R. 2009.

A importância das indústrias, do comércio, dos serviços e de sua localização geograficamente estratégica, tende a gerar para Marabá, também, um fluxo populacional intenso, que se inicia na década de 1980, e que tem se reforçado ao longo dos anos, conforme a dinâmica econômica regional atraiu populações e agentes diversos em uma escala considerável nos últimos 40 anos, como se nota na tabela a seguir.

\begin{tabular}{|c|c|c|c|}
\hline Anos & População(Hab.) & Área $(\mathbf{K m 2})$ & $\begin{array}{c}\text { Densidade } \\
(\mathbf{H a b} . / \mathbf{K m} \mathbf{2})\end{array}$ \\
\hline 1980 & 59.915 & $37.373,00$ & 1,6 \\
\hline 1991 & 123.668 & $15.288,16$ & 8,09 \\
\hline 1996 & 150.095 & $15.157,90$ & 9,9 \\
\hline $1997\left(^{1}\right)$ & 156.685 & $15.157,90$ & 10,34 \\
\hline $1998\left(^{1}\right)$ & 162.236 & $15.157,90$ & 10,7 \\
\hline $1999\left(^{1}\right)$ & 167.795 & $15.157,90$ & 11,07 \\
\hline 2000 & 168.020 & $15.092,30$ & 11,08 \\
\hline $2001\left(^{1}\right)$ & 173.301 & $15.092,30$ & 11,48 \\
\hline $2002\left(^{1}\right)$ & 177.352 & $15.092,30$ & 11,75 \\
\hline $2003\left(^{1}\right)$ & 181.683 & $15.092,30$ & 12,04 \\
\hline $2004\left(^{1}\right)$ & 191.508 & $15.092,30$ & 12,69 \\
\hline $2005\left(^{1}\right)$ & 195.807 & $15.092,30$ & 12,97 \\
\hline $2006\left(^{1}\right)$ & 200.801 & $15.092,30$ & 13,3 \\
\hline $2007\left(^{1}\right)$ & 205.753 & $15.092,30$ & 13,63 \\
\hline
\end{tabular}

Tabela 3: População, área e densidade demográfica 1980/91/96-2007

Fonte: GOVERNO DO PARÁ/SEPOF, 2007.

(1) População Estimada. 


\subsection{As dinâmicas industriais e a centralidade de Marabá no eixo das horizontalidades e das verticalidades}

Para se entender a presença de indústrias em Marabá é preciso, antes, discutir o processo de desconcentração industrial vivenciado pelo Brasil depois dos anos 1970, pois foi a partir desse período que se iniciou uma reestruturação produtiva (e espacial) sem precedentes no País. De acordo com Sposito (2000), a rede urbana brasileira foi se estabelecendo e criando uma hierarquização de acordo com a integração da economia e da sociedade nacional ao modo capitalista de produção. Para a compreensão desse processo, a autora propõe três momentos.

O primeiro, entre 1930 e 1950, em que surgiram iniciativas públicas e privadas com o intuito de estabelecer bases materiais para o desenvolvimento da industrialização no País. O segundo, desencadeado a partir de 1955 até parte dos anos 1980, em que ocorreu a desconcentração de parte da produção de países de industrialização consolidada para países com a base de sua produção apoiada no setor primário. $O$ terceiro compreende o final do século XX, que, na passagem do sistema fordista para o sistema flexível de produção, desencadeia novas dinâmicas, como a ampliação da importância das grandes metrópoles com o aumento dos papéis de gestão empresarial e financeira do capital, descentralização da atividade produtiva, aumentando o papel de cidades grandes e médias.

Segundo Cano e Guimarães Neto (1986), o mapa da distribuição regional do valor de transformação industrial mostra, para o ano de 1970, uma forte concentração do parque industrial brasileiro, que chega a $80,66 \%$ na região Sudeste $(58,23 \%$ apenas em São Paulo), ficando as outras regiões com somente $19,34 \%$ (11,99\% no Sul, 5,74\% no Nordeste, $0,82 \%$ no Norte, e $0,79 \%$ no Centro-Oeste).

Ainda segundo esses autores, foi também a partir desse momento que a pressão da periferia começou a surtir efeitos sobre o Estado, que repensou seus investimentos para a indústria e o desenvolvimento do País, através de políticas de desenvolvimento regional, expressas, em grande medida, nos sucessivos PND’s (Planos Nacionais de Desenvolvimento) - I PND (1970-1974), direcionado à modernização da agricultura, II PND, voltado a redistribuição da indústria, III PND (1980-1985), para correção de rumos (MOREIRA, 2004). O resultado desse processo foi a localização do capital produtivo também na periferia do território, estabelecendo, assim, uma acumulação em nível nacional que beneficiou os grupos 
econômicos já consolidados do Centro-Sul por meio da venda de insumos e de bens de capital.

Para a Amazônia, o resultado dessas políticas foi a sua transformação, ainda nos anos 1970, em uma fronteira econômica, e, no caso de Marabá e do Sudeste Paraense, essa mudança ocorreu tanto do ponto de vista de sua estrutura produtiva, quanto de seu papel na rede urbana regional.

Segundo Coelho (2007), a mineração tem um papel fundamental nas novas dinâmicas empreendidas na região, de maneira que contribuiu para a penetração do povoamento, para a expansão das tensões sociais para o interior, para a interiorização do processo de urbanização e da hierarquização das cidades e, além disso, propiciou ainda, a formação de redes técnicas, que fomentaram o surgimento de forças produtivas de efeitos seletivos e gradativos.

A autora destaca, ainda, que os grandes empreendimentos mineradores geraram, nessa porção da Amazônia, um crescimento populacional e fragmentações territoriais que permitem elucidar uma questão mais recente: a da divisão do Estado e a criação do Estado de Carajás, com sedem em Marabá. Por fim, Coelho (2007) aponta a inserção de novos fixos - mina, ferrovias e hidrelétrica -, que garantem fluxos de exportação, e em menor escala, fluxos de importação, que se originam dessa nova dinâmica econômica.

Ainda de acordo com a autora, no caso específico de Marabá, que teve uma mudança de uma "economia extrativa" para uma "economia de produção", sua dinâmica socioespacial deve ser compreendida a partir do processo de transformação seletiva das economias regionais, estaduais e locais, permeadas, no caso da Amazônia oriental, pelo forte papel exercido pelos empreendimentos mineradores (COELHO, 2007).

\subsubsection{Marabá no centro das transformações socioespaciais}

No processo de desconcentração industrial no Brasil, Sposito (2007) aponta a relação da mudança espacial da indústria com a mudança do papel das cidades na rede urbana, em que cidades de porte médio passam a receber equipamentos para a estruturação de seus parques industriais e o conjunto de objetos e ações (SANTOS, 2002), desencadeadas por esse movimento, passam a redefinir os papéis dessas cidades na rede urbana de suas respectivas regiões.

Entretanto, deve-se atentar que o processo de desconcentração da indústria, tal como outras dinâmicas, devem ser compreendidas a partir das formações socioespaciais das realidades regionais em que se inserem. Isto se faz necessário em nossa análise, posto que, na 
região Sudeste, e particularmente no Estado de São Paulo, esse processo ocorreu no sentido da desconcentração e reconcentração espacial dos parques industriais (fixos) estabelecidos nas regiões metropolitanas para cidades de porte médio, sendo tais indústrias de grande porte e de alta tecnologia, mas, por outro lado, houve uma centralização espacial dos capitais produtivos e financeiros na metrópole paulista, conforme aponta Sposito (2000).

No caso da região amazônica, e particularmente do Sudeste Paraense e da cidade de Marabá, o que se nota é que esse processo não ocorreu no sentido de uma desconcentração industrial da metrópole para as cidades de médio porte. A indústria que se estabelece na região, por um lado, é proveniente de outras regiões brasileiras, sendo esta caracterizada por grandes empreendimentos econômicos de capital internacional e privado, com uma tecnologia nelas empregadas que corresponde apenas ao beneficiamento primário de seus produtos (caso da indústria siderúrgica). Por outro lado, estabelece-se uma indústria de pequeno porte, com capitais regionais e de baixa tecnologia, mas que também são importantes na dinâmica econômica de Marabá, no sentido de que fortalecem sua centralidade regional na distribuição de sua produção para atender a uma demanda local (caso das indústrias da construção civil, da indústria agropecuária - leiteiras e frigoríficos, e da indústria moveleira).

As transformações socioespaciais ocorridas nesse processo, em que a indústria se instala na região (através de um projeto de modernização e desenvolvimento regional) se refletiram na mudança da estrutura produtiva do Sudeste Paraense, e, nesse caso, também na cidade de Marabá, que passa de uma dinâmica econômica atrelada ao extrativismo (especialmente madeira e castanha) para uma dinâmica mais voltada à produção mineral. E, nesse processo, as ações do Estado contribuíram, não apenas para a transformação da paisagem regional, com a criação dos grandes projetos mínero-metalúrgicos (Programa Grande Carajás, com os projetos Ferro Carajás, Albras-Alunorte, Hidrelétrica de Tucuruí etc.), de projetos de assentamento e colonização agrícola (criação das agrovilas, agrópolis e rurópolis), bem como a criação de infra-estruturas de suporte a esses projetos, como a abertura de rodovias, ferrovias, portos e aeroportos, e a criação de cidades das companhias, as company towns, como as denomina Becker (1990a), para assentar os trabalhadores dessas empresas.

Mas, ao mesmo tempo, essa reorganização espacial, com um expressivo crescimento populacional, acabou gerando uma periferização das grandes cidades e cidades de médio porte, e, ainda, alterando um conjunto de ações e relações até então existentes na região, que estavam voltadas para uma cultura extrativa e um modo de vida atrelado ao rio, ao tempo 
lento, e passa para uma vivência da estrada, da rapidez, ao espaço da circulação mais fluida (SANTOS, 1996).

No caso específico da cidade de Marabá, essa reestruturação produtiva, que conduz, também, a uma reestruturação espacial da cidade, dá-se a partir de ações estatais, tendo em vista sua posição geográfica no entroncamento de vias de circulação regionais (especialmente as rodovias BR-230 - Transamazônica -, PA-150 e a estrada de ferro Carajás), conferindo a ela um papel de centralidade na convergência de investimentos de capitais, bens e serviços, e da infra-estrutura logística, voltada para atender a uma nova demanda de capitais, que não os regionais.

Esses empreendimentos contaram ainda com o benefício de recursos oriundos do Fundo de Investimento do Norte (FINAN) e do Fundo de Investimento do Nordeste (FINOR), repassados pelas então agências de desenvolvimento do Norte e Nordeste - Superintendência do Desenvolvimento da Amazônia (SUDAM) e Superintendência do Desenvolvimento do Nordeste (SUDENE), das quais receberiam até 75\% do valor para a implementação de seus parques industriais, bem como para a obtenção de terras para seus projetos de manejo florestal e reflorestamento, conforme afirma Monteiro (1997).

Essa nova dinâmica produtiva e espacial tem como elementos importantes, ainda, as contradições socioespaciais decorrentes desse processo, tendo em vista que a implantação da indústria siderúrgica na Amazônia, e neste caso na cidade de Marabá, ocorre, além dos elementos anteriormente apontados, através da "necessidade" de barateamento dos custos da produção desse tipo de indústria, de forma que, nesse processo produtivo, não há verticalização da produção, em decorrência da grande quantidade e do alto custo do carvão vegetal, utilizado na produção industrial (MONTEIRO, 1997).

Dessa maneira, essa reestruturação produtiva, através da indústria siderúrgica, originou ainda o aparecimento da atividade do carvoejamento (MONTEIRO, 1997), propiciando uma inter-relação entre a cidade e a região de entorno de Marabá Cidades como Dom Eliseu, Rondon do Pará, Jacundá, Tailândia, entre outras, incluem, na atividade da indústria madeireira, a produção do carvão vegetal ${ }^{15}$.

\footnotetext{
${ }^{15}$ Em princípio o processo de produção do carvão vegetal era feito apenas pelas indústrias madeireiras, o que se tem hoje é um crescimento dessa produção nas propriedades rurais destas cidades, que buscam atender à demanda das indústrias siderúrgicas (AMARAL, 2007). Para melhor compreensão deste tema ver estudos realizados por Amaral (2006 e 2007).
} 
Essa nova dinâmica econômica teve ainda como resultado, a geração e intensificação de conflitos de ordem fundiária, de modo que a aquisição contínua de terras por esses empreendimentos contribuiu para aumentar ainda mais as contradições da estrutura fundiária da região e constituiu relações de caráter conservador com os demais agentes sociais locais que também estabeleciam através do latifúndio suas relações de poder (MONTEIRO, 1997).

Ressalta-se, ainda, no que diz respeito à dinâmica industrial de Marabá, a importância da indústria da construção civil, especialmente a produção de dois dos seus principais insumos (o beneficiamento da madeira - portas e forros - e a fabricação de telhas e tijolos), conforme indica a Prefeitura de Marabá (2006). Além desta, há ainda a indústria de laticínios (beneficiamento do leite e produção de derivados) e a frigorífica, no setor agropecuário, bem como a indústria moveleira (beneficiamento de artefatos de madeira na produção de móveis).

Todavia, a reestruturação espacial da cidade, que tem como um de seus elementos principais a reestruturação produtiva e as ações estatais de desenvolvimento regional, mostram uma dinâmica urbana mais intensa a partir da implantação desses novos objetos espaciais, com um crescimento populacional muito rápido, que contribuiu para a expansão da cidade, a implantação de serviços anteriormente inexistentes e para a expansão da própria infraestrutura urbana, permitindo uma maior circulação de capitais, bens e serviços.

\subsubsection{A dinâmica industrial recente e a reestruturação do espaço}

No que se refere à dinâmica industrial recente, tem-se que o setor industrial desempenha um papel fundamental na economia da cidade de Marabá, partindo-se aqui da composição do PIB municipal, segundo dados do IBGE (2009), este setor é o segundo componente mais importante, com um valor adicionado correspondente a 1.012.952, depois do setor de comércio e serviços, com valor adicionado equivalente a 1.619.530, como demonstra o gráfico 3 . 


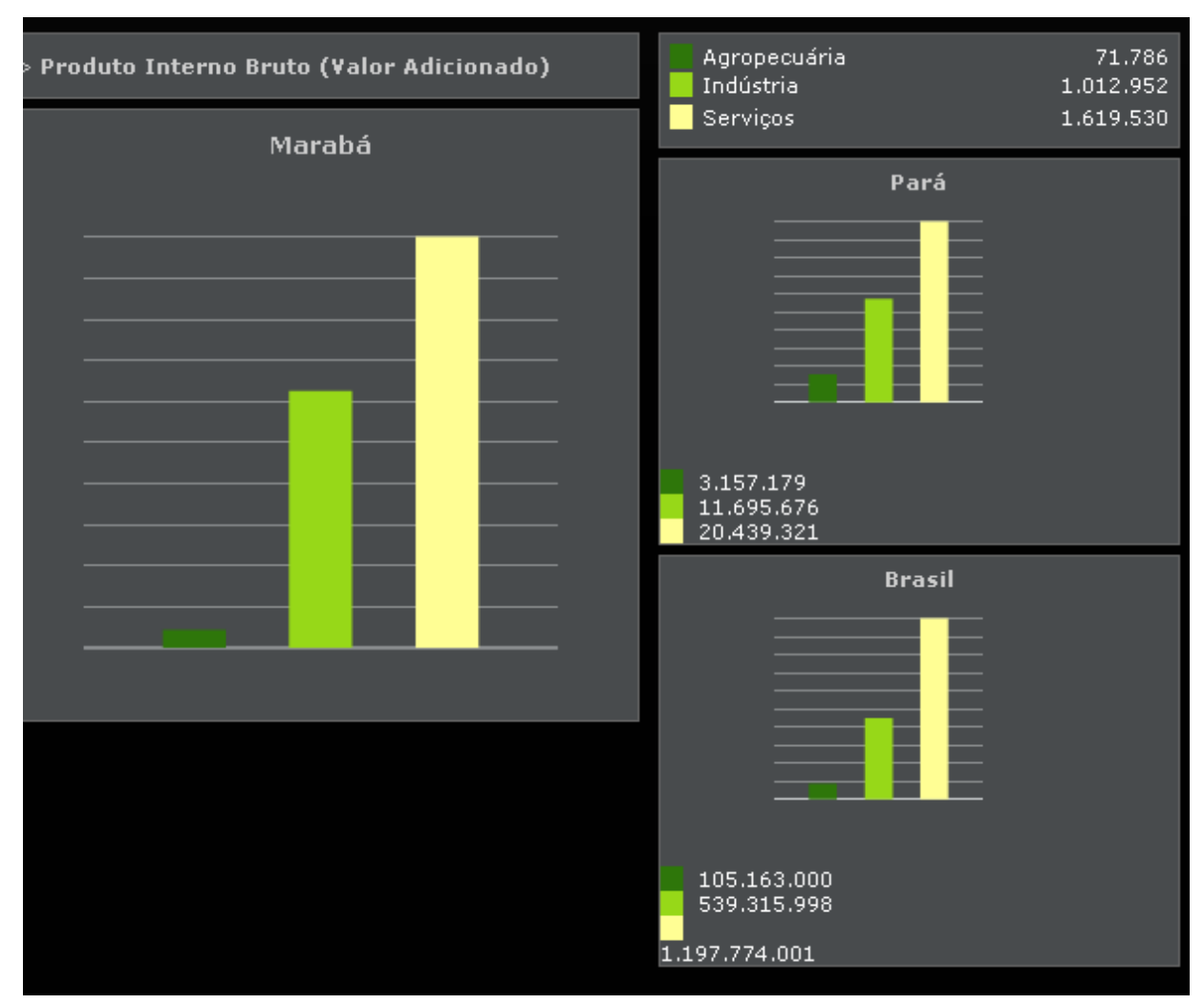

Gráfico 3 - Produto Interno Bruto (VALOR ADICIONADO)

Fonte: IBGE (2009)

O parque industrial de Marabá está localizado no Distrito Industrial, conforme mapa 8, área especificamente criada para sua instalação no final da década de 1980, e possui uma área total de 2.886 hectares.

O parque industrial possui um número significativo de siderúrgicas - 11 instaladas, mais uma em processo de instalação, a $\operatorname{SINOBRAS}^{16}$-, dentre as quais a maior produtora é a Companhia Siderúrgica do Pará (COSIPAR), com um valor correspondente a 46.560 toneladas por mês, número significativo quando se compara com o total da produção do conjunto das indústrias siderúrgicas que corresponde a 213.893 toneladas por mês, de acordo com os dados da Prefeitura Municipal (2006), apresentados na tabela 4.

\footnotetext{
${ }^{16}$ Implementada com recursos do governo federal e da CVRD, sendo até o presente momento a indústria com a mais avançada tecnologia do setor siderúrgico na região.
} 


\begin{tabular}{|c|c|c|c|c|}
\hline SIDERÚRGICAS & $\begin{array}{c}\text { NÚMERO } \\
\text { DE } \\
\text { FORNOS }\end{array}$ & $\begin{array}{l}\text { PRODUÇÃO } \\
\text { MÊS (TON.) }\end{array}$ & $\begin{array}{c}\text { PRODUÇÃO } \\
\text { ANUAL (TON.) }\end{array}$ & $\begin{array}{l}\text { EMPREGO } \\
\text { S DIRETOS }\end{array}$ \\
\hline \multicolumn{5}{|l|}{$\begin{array}{l}\text { INSTALADAS HÁ MAIS } \\
\text { TEMPO }\end{array}$} \\
\hline Cosipar & 5 & 46.560 & 558.720 & 760 \\
\hline Simara & 2 & 18.000 & 216.000 & 400 \\
\hline Usimar & 2 & 19.000 & 228.000 & 480 \\
\hline Ibérica & 2 & 27.000 & 324.000 & 200 \\
\hline Terranorte & 2 & 11.000 & 132.000 & 170 \\
\hline Sidepar & 1 & 18.000 & 216.000 & 150 \\
\hline Sidenor (início op. Ago. 2005) & 1 & 13.000 & 156.000 & 200 \\
\hline $\begin{array}{l}\text { Ferro Gusa Carajás (inicio op. } \\
\text { Jun. de 2005) }\end{array}$ & 2 & 30.000 & 360.000 & 200 \\
\hline Subtotal (1) & 17 & 182.560 & 2.190 .720 & 2.460 \\
\hline \multicolumn{5}{|l|}{$\begin{array}{r}\text { INSTALADAS } \\
\text { RECENTEMENTE } \\
\end{array}$} \\
\hline Da Terra (Grupo Revemar) & 1 & 15.000 & 180.000 & 350 \\
\hline Maragusa ( Grupo Leolar) & 1 & 15.000 & 180.000 & 350 \\
\hline Fermar (ferro-liga) & 2 & 1.333 & 16.000 & 135 \\
\hline Sub-total (2) & 4 & 31.333 & 376.000 & 835 \\
\hline TOTAL DA PRODUÇÃO ( $1+2)$ & 21 & 213.893 & 2.566 .720 & 3.295 \\
\hline
\end{tabular}

Tabela 4: Produção das Siderúrgicas Instaladas no Distrito Industrial - 2006

Fonte: Marabá (2006).

As siderúrgicas, conforme dito anteriormente, ocupam grandes áreas no parque industrial e propiciam uma grande circulação de pessoas e automóveis de grande porte (caminhões), em virtude da necessidade do abastecimento de sua principal fonte de energia no processo de beneficiamento do ferro (Fotos 13, 14 e 15).

Do ponto de vista da importância do capital industrial para a economia do Município, a produção industrial de Marabá possibilita uma arrecadação do IPI (Imposto sobre Produtos Industrializados) correspondente a R $\$ 682.675,20$, o que lhe coloca em quarto lugar entre os municípios do Estado que também possuem essa arrecadação, estando atrás apenas de Belém (capital do Estado), com R\$2.405.117,23, Parauapebas (onde se localiza a mina de minério de ferro da CVRD), com R\$ 1.051.436,50, e Barcarena (onde se localiza o parque industrial da Albras/Alunorte), com R\$ 750.359,23 (tabela 5). 


\begin{tabular}{|c|c|c|}
\hline MUNICÍPIOS & $\begin{array}{c}\text { TOTAL DO } \\
\text { SEMESTRE }\end{array}$ & \% QUOTA-PARTE \\
\hline Almeirim & $155.206,50$ & 1,33 \\
\hline Altamira & $189.048,52$ & 1,62 \\
\hline Ananindeua & $506.463,31$ & 4,34 \\
\hline Barcarena & $750.359,23$ & 6,43 \\
\hline Belém & $2.405 .117,23$ & 20,61 \\
\hline Canaã dos Carajás & $210.053,91$ & 1,80 \\
\hline Castanhal & $177.378,85$ & 1,52 \\
\hline Itaituba & $127.199,31$ & 1,09 \\
\hline Marabá & $\mathbf{6 8 2 . 6 7 5 , 2 0}$ & $\mathbf{5 , 8 5}$ \\
\hline Oriximiná & $316.247,83$ & 2,71 \\
\hline Paragominas & $159.874,36$ & 1,37 \\
\hline Parauapebas & $1.051 .436,50$ & 9,01 \\
\hline Santarém & $268.402,21$ & 2,30 \\
\hline Tucuruí & $547.307,12$ & 4,69 \\
\hline
\end{tabular}

5: Municípios com maiores repasses de IPI (PRIMEIRO SEMESTRE DE 2008)

Tabela

Fonte: GOVERNO DO ESTADO DO PARÁ. Secretaria de Estado da Fazenda, Diretoria do Tesouro Estadual, 2008.

A composição da base econômica de Marabá demonstra um crescimento favorável no que se refere ao setor industrial, no período entre os anos de 1997 a 2004. No primeiro ano de referência o setor industrial correspondia a R\$ 136.004, 00 (36,32\%), e em 2004 esse valor subiu para $\mathrm{R} \$ 748.516,00$ (52,01\%), sendo mais da metade do total da economia municipal, o que ratifica a importância desse setor para a dinâmica local (tabela 6).

\begin{tabular}{|c|c|c|c|c|}
\hline ANO & AGROPECUÁRIA & INDÚSTRIA & $\begin{array}{c}\text { COMÉRCIO E } \\
\text { SERVICOS }\end{array}$ & TOTAL \\
\hline 1997 & $33.128(8,85)$ & $136.004(36,32)$ & $205.267(54,83)$ & $374.399(100)$ \\
\hline 1998 & $35.739(8,49)$ & $158.105(37,56)$ & $227.071(53,95)$ & $420.915(100)$ \\
\hline 1999 & $40.159(8,42)$ & $192.369(40,35)$ & $244.272(51,23)$ & $476.800(100)$ \\
\hline 2000 & $41.445(7,46)$ & $252.929(45,55)$ & $260.927(46,99)$ & $555.301(100)$ \\
\hline 2001 & $50.663(7,40)$ & $274.301(40,07)$ & $359.586(52,53)$ & $684.550(100)$ \\
\hline 2002 & $83.254(11,44)$ & $262.896(36,12)$ & $381.763(52,44)$ & $727.913(100)$ \\
\hline 2003 & $94.790(10,13)$ & $378.921(40,50)$ & $461.813(49,37)$ & $935.524(100)$ \\
\hline 2004 & $148.499(10,32)$ & $748.516(52,01)$ & $542.105(37,67)$ & $1.439 .120(100)$ \\
\hline
\end{tabular}

Tabela 6: Base econômica do município (1997-2004) (Valores em R $\$$ mil/\%)

Fonte: IBGE, 2007.

Organização: Rovaine Ribeiro.

Outro elemento a ser considerado na dinâmica industrial é o papel do setor na geração de empregos, que, de acordo com os dados do Ministério do Trabalho e Emprego (MTE), entre 2000 e 2007, teve importância significativa e um aumento na oferta de empregos, 
especialmente no setor da indústria de transformação, principal atividade do parque industrial de Marabá, que teve uma variação entre 649 admissões em 2000, subindo para 2.569 em 2007 (tabela 7).

\begin{tabular}{|c|c|c|c|c|c|c|c|c|}
\hline & 2000 & 2001 & 2002 & 2003 & 2004 & 2005 & 2006 & 2007 \\
\hline $\begin{array}{l}\text { Atividade } \\
\text { Econômica } \\
\text { Extrativa Mineral }\end{array}$ & $\begin{array}{c}\text { Total } \\
\text { Admis. } \\
17\end{array}$ & $\begin{array}{c}\text { Total } \\
\text { Admis. } \\
20\end{array}$ & $\begin{array}{c}\text { Total } \\
\text { Admis. } \\
19\end{array}$ & $\begin{array}{c}\text { Total } \\
\text { Admis. } \\
41\end{array}$ & $\begin{array}{c}\text { Total } \\
\text { Admis. } \\
46\end{array}$ & $\begin{array}{c}\text { Total } \\
\text { Admis. } \\
155\end{array}$ & $\begin{array}{c}\text { Total } \\
\text { Admis. } \\
187\end{array}$ & $\begin{array}{c}\text { Total } \\
\text { Admis. } \\
49\end{array}$ \\
\hline Ind. Transformação & 649 & 977 & 1.049 & 1.154 & 1.540 & 3.208 & 2.661 & 2.569 \\
\hline Serv. Ind. Util. Pub. & 145 & 75 & 57 & 26 & 23 & 34 & 57 & 18 \\
\hline Construção Civil & 426 & 229 & 603 & 753 & 931 & 373 & 713 & 946 \\
\hline Comercio & 1.225 & 1.720 & 1.893 & 2.220 & 2.582 & 3.584 & 3.787 & 4.366 \\
\hline Serviços & 584 & 760 & 968 & 1.079 & 1.126 & 1.799 & 2.203 & 2.283 \\
\hline Adm. Pública & 0 & 1 & 0 & 0 & 1 & 3 & 1 & 2 \\
\hline Agropecuária & 81 & 112 & 187 & 723 & 1.414 & 1.932 & 1.198 & 696 \\
\hline Outros & 3 & 3 & 11 & 0 & 10 & 0 & 0 & 0 \\
\hline Total & 3.130 & 3.897 & 4.787 & 5.996 & 7.673 & 11.088 & 10.807 & 10.929 \\
\hline
\end{tabular}

Tabela 7: Evolução do emprego por setor de atividade econômica - 2000/2007*

Fonte: MTE - Cadastro Geral de Empregados e Desempregados - LEI 4923/65, 2009.

Elaboração: Rovaine Ribeiro.

*Os dados correspondem apenas aos trabalhadores admitidos nos setores de atividade econômica.

Os dados de evolução do emprego por setor de atividade econômica revelam ainda que, além da indústria de transformação (no caso a indústria siderúrgica), o setor da construção civil tem também um papel importante no tocante ao emprego formal, correspondendo, em 2000, a 426 admitidos e, em 2007, a 946.

Entretanto, deve-se ressaltar que houve algumas mudanças no setor industrial nos últimos anos em Marabá. De acordo com a ACIM (Associação Comercial e Industrial de Marabá), à Maragusa e à SINDIFERRO (Sindicato da Indústria de Ferro de Marabá) em 2010, existem na atualidade onze indústrias de produção de ferro gusa instaladas (COSIPAR, SINOBRAS, IBÉRICA, TERRA NORTE/CIKEL, DA TERRA, SIDENORTE, SIDEPAR, MARAGUSA, FERRO GUSA CARAJÁS, BURITIRAMA e USIMAR), mas, desse total, a metade está atualmente com sua principal produção (ferro-gusa) parada, em função da crise ocorrida no mercado internacional desde o final de 2008.

O impacto da crise internacional nesse setor ocorreu em função de que $80 \%$ da produção que se realiza no Município é exportada para os Estados Unidos da América (EUA) e ainda para o Canadá, o Japão e a China. Com a crise, a exportação de ferro-gusa baixou de 241.044 
(jan./2008) para 19.737 toneladas (jan./2009), o que refletiu também na redução de postos de trabalho desse setor ${ }^{17}$.

Esse processo reflete o alto grau de solidariedade organizacional e o grau de verticalidade $^{18}$ dos investimentos que foram realizados nas últimas décadas em Marabá, articulando-a de forma intensiva aos espaços de comando da economia mundial e que a colocam em forte dependência aos fluxos e às vulnerabilidades do mercado global, em uma lógica que representa o jogo das relações entre as "regiões que perdem" e as "regiões que ganham" (BENKO, LIPIETZ, 1994), ou ainda, para usar os termos de Santos (1994), das "regiões do mandar" e das "regiões do fazer". Essa vulnerabilidade tem também contribuído para ratificar a existência de contradições socioespaciais locais, reforçadas pela redução de postos de trabalhadores no setor industrial, por exemplo.

Trata-se de uma dinâmica bem característica do período atual, denominado por Santos (2006) de período técnico-científico informacional, cujas verticalidades passam a coexistir com as horizontalidades, definindo maior complexidade a determinadas realidades locais e regionais. Em outros termos, os nexos de energia são substituídos por nexos de informação, em que se definem recortes horizontais - espaços contínuos, formados de partes agregadas, condição e resultado das relações de produção propriamente dita -, e verticais - pontos separados uns dos outros que asseguram o funcionamento global da sociedade e da economia, e que resultam das novas necessidades de intercâmbio e de regulação (SANTOS, 1994).

No que concerne ao setor da construção civil, em estudo sobre a cadeia produtiva da construção civil no Estado do Pará, realizado para a composição do Diagnóstico do Plano Estadual de Habitação de Interesse Social (PEHIS), em 2009, identificou-se que os municípios que tiveram maior expressão nesse setor foram Marabá, com crescimento na ordem de 224,13\%; Parauapebas com 222,73\%; Ananindeua, com 165,93\%; Paragominas, com 76,14\%; e Belém que apresentou 58,98\%.

No que se refere à produção e circulação dos produtos dessa cadeia produtiva, na Região de Integração Carajás ${ }^{19}$ da qual Marabá é o Município pólo, constata-se que a fabricação de

\footnotetext{
${ }^{17}$ As informações foram obtidas através de entrevistas realizadas com o senhor Zeferino Abreu Neto - diretor da Siderúrgica Maragusa, com o diretor comercial da ACIM, e de dados levantados junto ao SINDIFERRO, realizados em trabalho de campo em janeiro de 2010.

${ }_{18}$ Para Santos $(1994,2006)$, essas noções expressam atributos do espaço no período técnico-científicoinformacional que vivemos, marcado pela menor rigidez do ponto de vista da continuidade e da contigüidade absoluta, que demarcaram em outros tempos maiores horizontalidades e solidariedades orgânicas do ponto de vista espacial. Diferentemente, hoje, convivendo com aquelas, mas ganhando cada vez mais notoriedade, as solidariedades organizacionais tendem a substituir as solidariedades orgânicas de outrora

${ }^{19}$ A partir da Resolução $\mathrm{n}^{\circ} 002$ de 5 de fevereiro de 2004, o Governo do Estado criou uma nova regionalização do território paraense e, com o Decreto $\mathrm{n}^{\mathrm{o}} 1.066$ de 19 de junho de 2008, tal regionalização instituída passou a denominar-se Regiões de Integração. Essa nova regionalização é composta 12 regiões de Integração, são elas:
} 
telhas e tijolos é realizada na região e distribuída para o mesmo mercado consumidor (PEHIS, 2009).

A tabela 8 demonstra a arrecadação de ICMS (Imposto sobre a Circulação de Mercadorias e Serviços) na atividade da construção civil no Estado do Pará, em 2006. Devido à concentração de muitas empresas no setor da construção civil na Região Metropolitana, esta atividade tende a arrecadar mais impostos. Para o caso específico do ICMS, 66,08\% dessa arrecadação se concentrou na Região Metropolitana, seguida das Regiões Carajás (4,86\%) e Araguaia (4,72\%), onde o mercado da construção civil está em desenvolvimento.

\begin{tabular}{l|c||c}
\hline \hline Regiões de Integração & $\begin{array}{c}\text { ICMS } \\
\mathbf{2 0 0 6}\end{array}$ & $\begin{array}{c}\text { PARTICIPAÇÃO } \\
(\mathbf{\%})\end{array}$ \\
\hline \hline Araguaia & $1.964 .030,70$ & 4,72 \\
\hline Baixo Amazonas & $2.021 .619,27$ & 4,86 \\
\hline Carajás & $\mathbf{2 . 5 0 5 . 1 0 1 , 8 6}$ & $\mathbf{6 , 0 2}$ \\
\hline Guamá & $1.925 .434,72$ & 4,63 \\
\hline Lago de Tucuruí & $923.676,33$ & 2,22 \\
\hline Marajó & $344.207,38$ & 0,83 \\
\hline Metropolitana & $27.500 .462,84$ & 66,08 \\
\hline Rio Caeté & $540.013,50$ & 1,30 \\
\hline Rio Capim & $1.379 .510,03$ & 3,31 \\
\hline Tapajós & $778.255,62$ & 1,87 \\
\hline Tocantins & $1.005 .370,44$ & 2,42 \\
\hline Xingu & $732.083,29$ & 1,76 \\
\hline \hline TOTAL & $41.619 .765,98$ & 100 \\
\hline \hline
\end{tabular}

Tabela 8: Arrecadação de ICMS na construção civil por regiões de integração - 2006 Fonte: SEFA, 2006.

Elaboração: PEHIS, 2009.

Nesse sentido, nota-se que a indústria da construção civil, também aparece com um papel significativo no que se refere à dinâmica industrial recente de Marabá, levando-se em conta que não se trata de um perfil de indústria de alta tecnologia, mas que, do ponto de vista econômico, é bastante representativo para o Município. Segundo informações da Secretaria Municipal de Meio Ambiente de Marabá (SEMMA), em 2010, esse setor passou a contar com 33 cerâmicas; 3 construtoras de artefatos de cimento; 94 empresas de extração de areia, cascalho, saibro e argila; 8 fábricas de peças, ornatos e estruturas de cimento e gesso; e 34 serralherias, presente no município, o que revela a importância do crescimento nesse setor, especialmente nos últimos dois anos, o que também se reforça com o crescimento do mercado imobiliário do município. 
No que concerne ainda ao mercado de trabalho, há uma preocupação na formação de uma mão-de-obra regional, voltada para atender às demandas das indústrias locais. No Município existem hoje alguns cursos de graduação especificamente voltados para as indústrias minerais, dentre eles destacam-se: a) graduação em Engenharia de Minas e Meio Ambiente, Engenharia de Materiais e Geologia, e especialização em Tecnologia Mineral e Metalurgia, da Universidade Federal do Pará; b) graduação em Engenharia Ambiental e Tecnologia Agroindustrial, da Universidade do Estado do Pará; e, c) graduação de Engenharia de Produção (EAD), da Faculdade Metropolitana. Além destas instituições de ensino superior, há ainda doze faculdades privadas com cursos de graduação e pós-graduação (especialização) de ensino à distância, em sua maioria voltados para a área de administração, ciências contábeis, direito, gestão de negócios imobiliários, produção industrial, saúde e educação ${ }^{20}$.

Entretanto, o que se observa é, ainda, a pouca absorção dessa mão-de-obra especializada local junto aos grandes empreendimentos mínero-metalúrgicos. A maior parte dos empregos formais nessas indústrias ainda se trata de uma mão-de-obra menos especializada, ou quando especializada, vinda de outros estados brasileiros, embora existam alguns projetos de parceria entre a Universidade Federal do Pará e a CVRD, para esses cursos.

O terceiro elemento a ser considerado em relação ao papel da indústria em Marabá diz respeito à indústria moveleira, que, de acordo com a SEMMA (2010), possui 54 empresas do setor no Município. Além disso, há ainda o projeto "Móveis e artefatos de madeira no Sudeste do Pará", desenvolvido pelo Serviço de Apoio às Micro e Pequenas Empresas (SEBRAE), que realiza trabalhos de capacitação da produção à comercialização dos produtos, em parceria com prefeituras, BASA, Associação Industrial Moveleira de Jacundá, Associação das Indústrias Moveleiras de Marabá (ASSIMA), COOPMASP (Cooperativa da Indústria Moveleira e Serradores de Parauapebas), Governo do Estado do Pará e Instituto Brasileiro do Meio Ambiente e dos Recursos Naturais (IBAMA), promovendo uma articulação regional com Rondon do Pará, Parauapebas e Jacundá, Municípios envolvidos nesse projeto.

Por fim, destacam-se, ainda, as indústrias voltadas para o setor agropecuário, que aparecem como o terceiro setor produtivo em relação ao valor adicionado do PIB municipal, conforme dados do IBGE, no gráfico 3. Nesta área destacam-se os frigoríficos e a indústria leiteira. No primeiro caso, existem três frigoríficos no município, conforme informações da Secretaria de Agricultura de Marabá (SEAGRI, 2010), ambos pertencentes a grupos locais.

\footnotetext{
${ }^{20}$ Informações obtidas durante os trabalhos de campo em Marabá (2008 e 2009) junto à Universidade Federal do Pará (UFPA), Universidade Estadual do Pará (UEPA), Centro Federal de Educação Tecnológica-PA (CEFET) e Secretaria de Educação do Município. Os cursos das instituições públicas estão mais bem explicitados no quadro 3.
} 
No segundo caso, a indústria leiteira apresenta uma dinâmica central neste setor econômico na região. De acordo com o diretor executivo do Sindicato das Indústrias de Laticínios do Estado do Pará (SINDLEITE), com sede em Marabá, senhor Jorge Alcides da Silva Rocha, existem 27 empresas no Município; destas, apenas 17 são sindicalizadas, sendo elas de médio porte, algumas sob inspeção federal, outras sob inspeção estadual.

Essas empresas encontram-se ao longo das rodovias PA-150, em direção ao Município de Goianésia do Pará; da BR-222, em direção a Rondon do Pará; e da PA-273, em direção a São Félix do Xingu - todos são municípios do entorno de Marabá. Dentre as empresas deste setor, as maiores são a LEBOM e a Pará Leite, que atuam somente na região sudeste do Pará, além da Manacá, que se localiza nas proximidades de Belém, mas que também é associada. Os produtos beneficiados por essas empresas, são queijos (mussarela, prato, provolone e coalho), manteiga, iogurte e o leite longa vida UHT, produzido pela Manacá, que é beneficiado no Município de Mãe do Rio, cidade mais ao sul do Estado, mas cuja captação é feita nos municípios dos eixos anteriormente citados, tendo em vista que esta área é a maior bacia leiteira do Estado, em virtude da importância da atividade pecuária na região. Os municípios produtores são: Rondon do Pará - laticínio CNA (produtor de queijos), posto de coleta de leite (Manacá); Abel Figueiredo - laticínio Montanhês e capitação do leite ao longo da rodovia (BR-222) com tanques de resfriamento. Na PA-150, o Laticínio Ouro Bom, no Município de Jacundá; e a Vitolac, no Município de Nova Ipixuna, com vários postos de captação de leite e presença de tanques de resfriamento espalhados às margens da mesma rodovia.

O destino da produção é, em sua maioria, voltado ao mercado da região Nordeste Recife, Fortaleza, Natal, João Pessoa, Teresina -, especialmente no caso das indústrias que produzem os queijos do tipo mussarela e prato. Além destes locais, os produtos beneficiados destinam-se também para os estados de São Paulo e Rio de Janeiro. Apenas vinte por cento (20\%) da produção fica no Pará, devido ao fato de que a cidade de Marabá e as cidades vizinhas são abastecidas, sobretudo, de queijos de produção artesanal.

Em relação à produção e beneficiamento do leite, o consumo é do tipo $\mathrm{C}$, em torno de sete mil litros de leite por dia (em Marabá), que é um leite sem inspeção e fiscalização. A Lebom e a Pará Leite compram a matéria-prima dos Municípios de Marabá, São Domingos do Araguaia, Brejo Grande do Araguaia, Nova Ipixuna, Jacundá e Bom Jesus do Tocantins. A Lebom produz queijo mussarela, queijo prato, queijo qualho, queijo tropical ralado e manteiga. A Pará Leite produz os queijos mussarela, ricota e tropical ralado. Essas duas empresas atuam pouco no mercado local. A Pará Leite volta-se para São Paulo e a Lebom 
para o mercado do Nordeste, tendo em vista que o proprietário da Lebom é do estado do Ceará, e da Pará Leite é de São Paulo. Ambas estão em Marabá há bastante tempo, a Lebom há mais de quinze anos e a Pará Leite em aproximadamente dez anos, são elas que acabam promovendo, nesse setor, os fluxos inter-regionais.

A importância dessas indústrias para a cidade e para a região se dá no sentido de que elas estimulam o crescimento da bacia leiteira e geram empregos, contribuindo para o desenvolvimento do setor na região e garantindo a compra da produção. $O$ número de funcionários dessas empresas é em média de oitenta trabalhadores diretos e duzentos indiretos, no caso da Lebom. A Pará Leite possui cerca de cinqüenta funcionários diretos e cento e cinqüenta indiretos. A cadeia produtiva do setor leiteiro abrange a fazenda, o transporte e a industrialização.

O transporte do leite captado nas propriedades rurais é realizado de duas maneiras. No primeiro caso, o transporte se dá por meio de "latão", situação em que o produtor tira em média cinqüenta mil litros de leite que é recolhido todos os dias em "latão" pelo caminhão em sua porta, para posterior entrega na empresa. Na segunda situação, os produtores trabalham com tanques de resfriamento, e o produto sai direto da fazenda para o beneficiamento na indústria. No tanque, o leite é resfriado, e, em intervalos de dois em dois dias, o caminhãotanque da indústria faz a coleta do produto e transporta até a indústria. O volume de leite industrializado no Estado está em torno de dois milhões de litros por dia, envolvendo cerca de quarenta mil produtores. As duas empresas que estão em Marabá, a Lebom e a Pará Leite, beneficiam por dia, estimadamente, cinqüenta mil litros, e trinta e cinco mil litros, respectivamente.

Em termos de faturamento, a média em reais da Lebom é em torno de um milhão e meio, e da Pará Leite em torno de oitocentos e cinqüenta mil - estimativa calculada pelo preço do queijo e pelo volume de leite recebido, por cada uma delas. A produção não tem nenhuma relação com a capital Belém, senão do ponto de vista da fiscalização, em função de que as sedes dos órgãos fiscalizadores estão concentradas nessa cidade.

Além da atuação do sindicato, SEBRAE também tem um projeto neste setor é o "Leite e Derivados no Sudeste do Pará”, com o objetivo de aumentar a produção e a produtividade de leite nas pequenas propriedades, buscando qualificar o produto e seus derivados. Atualmente o projeto atende a 150 produtores dos Municípios de Canaã dos Carajás, Rondon do Pará, Parauapebas, Eldorado dos Carajás e Jacundá, tendo como parceiros as prefeituras municipais, a Empresa Brasileira de Pesquisas Agropecuárias (EMBRAPA), o Serviço Nacional de Aprendizagem Rural (SENAR), a Empresa de Assistência Técnica e Extensão 
Rural do Estado do Pará (EMATER) e o Ministério da Integração Nacional (MI) (SEBRAE, $2010)^{21}$

Dessa maneira, aponta-se que a dinâmica industrial de Marabá, mais recentemente, temse apresentado com uma configuração socioespacial que nos permite visualizar dois aspectos principais. O primeiro refere-se ao plano das verticalidades e das horizontalidades (SANTOS, 2002). Nesse aspecto, partimos da indústria siderúrgica, que estabelece relações diretas, no plano político e econômico, com agentes e capitais externos (nacionais e internacionais) com pouquíssimo vínculo com a dinâmica regional, refletindo as verticalidades que se criam na economia local. No que se refere às horizontalidades, tem-se as indústrias da construção civil, leiteira e moveleira, de capitais regionais, voltadas a atender às demandas de mercados locais e nacionais.

O segundo movimento diz respeito ao fato de que essas duas dinâmicas propiciam, do ponto de vista espacial dos fluxos, dois movimentos contrários e complementares, no sentido de que a produção siderúrgica estabelece uma rede local, com os municípios do entorno de Marabá, de absorção de insumo para a sua produção (o carvão vegetal), mas que, por outro lado, gera um fluxo extra-local de mercado consumidor dos produtos por ela beneficiados. De outro modo, a indústria da construção civil e a indústria leiteira, especialmente, estabelecem fluxos de escoamento da produção para um mercado consumidor local e nacional, propiciando o surgimento de redes regionais e nacionais, mas que mantêm capitais apenas internos nos seus investimentos.

Essas duas dinâmicas de fluxos mostram que a indústria também propicia um papel de centralidade regional para Marabá. A indústria siderúrgica reforça uma centralidade anterior, no estabelecimento de um conjunto de objetos e ações que se inserem na dinâmica socioespacial da cidade a partir dessa reestruturação produtiva regional. Por outro lado, as indústrias da construção civil e do setor agropecuário, criam uma centralidade mais recente, através da oferta de produtos que atendem a demandas locais e nacionais.

\footnotetext{
${ }^{21}$ Informações obtidas em entrevista realizada em janeiro de 2010 com a senhora Maria Luzineuza Alves G. da Maia, coordenadora do projeto, no escritório regional do SEBRAE em Marabá.
} 


\section{CONSIDERAÇÕES FINAIS}

Analisar a urbanização da Amazônia e o papel assumido pelas cidades médias na configuração de sua rede urbana, tomando como referência a realidade da Amazônia oriental, mais especificamente a cidade de Marabá, no sudeste paraense, nos impôs a necessidade de pensar, de um lado as transformações econômicas vivenciadas pela região, seguindo aquilo que na abordagem de Sposito $(2000 ; 2004)$ tem sido denominado de "reestruturação urbana", e que na leitura de Santos (1994) é chamado de "economia política da urbanização"; e de outro lado, as implicações dessas transformações na dinâmica intra-urbana, ou seja, naquilo que a autora supracitada tem denominado de "reestruturação da cidade", e que o autor anteriormente mencionado, chamou de "economia política da cidade".

Partindo dessas abordagens, procurou-se verificar como, ao longo do tempo, a região do sudeste paraense foi sendo modificada a partir das dinâmicas econômicas em que esteve envolvida, e como isso foi sendo implicado na estrutura interna da cidade de Marabá. Desse modo, fazendo uso da formação socioespacial, mostramos que a inserção de Marabá e do que à época era mais conhecido como médio Tocantins, no contexto amazônico, se deu num primeiro momento por atividades extrativas, tais como o caucho, a castanha e os cristais de rocha, que sob a égide do capital comercial mercantil de relações de trabalho baseadas na prática do aviamento e de uma estrutura de poder oligárquico, produziram uma cidade cujos limites são hoje definidos pela chamada Marabá Pioneira ou Velha Marabá, principalmente na porção imediatamente próxima à confluência dos rios Tocantins e Itacaiúnas. A Marabá desse período, era uma cidade que apresentava uma estrutura funcional pautada numa lógica econômica da comercialização de produtos extrativos, principalmente a castanha, não passando de uma cidade que durante muito tempo foi formada basicamente de "barracas" (DIAS, 1958) e sujeita às enchentes, que constantemente assolavam a região.

É somente depois da década de 1960, e principalmente 1970, que a cidade começa a se expandir além do núcleo da Marabá Pioneira. Dando origem, de um lado a um núcleo urbano planejado, a Nova Marabá, cujo traçado em forma de folhas de castanheira, sob intervenção direta do governo militar, por meio da SUDAM, teve grande dificuldade de ser efetivamente realizado; de outro lado, um núcleo mais "espontâneo", chamado de Cidade Nova, cuja origem está relacionada a implantação dos projetos de colonização agrícola, desenvolvidos pelo INCRA, na região, que transformaram a cidade de Marabá em uma das bases logísticas desse processo, mas também, a presença de um antigo bairro, o Amapá, que surgiu como suporte da Velha Marabá nos períodos, das grandes enchentes. 
Ainda nesse contexto em que a cidade funcionou como base logística para a implementação das políticas de desenvolvimento regional, cabe destacar o forte impacto sofrido pela cidade em função de atividades econômicas que mais uma vez atingiram a região depois de 1980. Dessa forma, ressalta-se o Projeto Ferro Carajás, os pólos siderúrgicos, a construção da Estrada de Ferro, os eixos rodoviários, a descoberta do ouro de Serra Pelada, entre outros, que impactaram diretamente a estrutura urbana municipal, que passou de 14.585 para 41.657 habitantes na década de 1970, e para 171.291 habitantes em 1988 (TOURINHO, 1991).

Por fim, no início dos anos 1990, a região é impactada mais uma vez por projetos de desenvolvimento regional, dessa vez fundado por um vetor tecno-ecológico (BECKER, 2005), e principalmente pela expansão de novas atividades econômicas, tais como, a ampliação da indústria siderúrgica articulada com os vetores da globalização que atingem mais fortemente a região, e as indústrias de base mais regional. Além disso, a cidade tem sido atingida por políticas voltadas à consolidação e ampliação do papel dessa cidade como um pólo na rede urbana regional. O resultado disso, tem se manifestado na instalação na cidade de infra-estrutura urbana, como saneamento, de habitação social, principalmente, nas áreas de risco da cidade, de desenvolvimento tecnológico, como o Parque de Ciência e Tecnologia (voltado ao desenvolvimento de tecnologia para produção) e o Projeto Navega Pará (voltado à instalação de redes de comunicação via internet de alta velocidade voltada a formação de banco de dados sobre a região e da cidade e facilitação do acesso a esse tipo de serviço), de ampliação e melhoria do Distrito Indústria da cidade, da instalação da empresa de aços e laminados da Vale (ALPA), da presença de empreendimentos imobiliários horizontais e verticais dentre outros.

Ao final de toda essa discussão a respeito da formação socioespacial de Marabá, chegamos a conclusão de que, a cidade passou de uma estrutura mononuclear à policentralidade, manifestada em seus três núcleos principais (Marabá Pioneira, Nova Marabá e Cidade Nova) e nos três secundários (São Félix, Morada Nova e Km 6), e cuja explicação deve ser buscada na articulação entre as dinâmicas intra-urbanas e interurbanas, ou na relação entre urbanização e cidades, que fez com que ela assumisse centralidade urbano-regional, observada no papel por ela desempenhado na atualidade.

Face a esta constatação, buscamos, no segundo momento do trabalho, analisar um dos aspectos da centralidade regional desempenhada por Marabá, as dinâmicas industriais e as conexões horizontais e verticais por elas propiciadas. Assim, analisamos ao longo do trabalho, dois tipos de centralidades, produzidas por essa dinâmica, a partir dos três principais setores 
industriais presentes na cidade de Marabá. A primeira, produzida pela indústria siderúrgica, acaba por estabelecer relações diretas com os agentes e os capitais exógenos, e com baixo nível de articulação regional, no que se refere à tomada de decisões. Desse modo, essas conexões verticais acabam reforçando as abordagens que vêem o papel da cidade média restrito ao aspecto puramente técnico, a exemplo de Santos e Silveira (2001). A segunda, resultado de dinâmicas mais horizontais, e que tem como suporte as indústrias da construção civil, moveleira e leiteira, mobilizadas em grande parte por capitais regionais, e voltadas para $\mathrm{o}$ atendimento de mercados locais e nacionais, propiciam a formação de redes cujo comando nem sempre é dado externamente, o que nos leva a avançar nas discussões sobre cidades médias, no sentido de pensá-las como desempenhando, também, papéis de natureza política, e não apenas técnica.

Recentemente, porém, devemos ressaltar o aparecimento de dois movimentos inversos na dinâmica industrial da cidade. O primeiro, da indústria siderúrgica, que após a última crise do mercado mundial, teve um refreamento de sua produção e de suas demandas junto ao mercado externo. O segundo, da indústria da construção civil, que teve um incremento significativo, a partir da nova política habitacional do Governo Federal, que subsidiou esse setor com a retirada do IPI sobre esses produtos, gerando um aumento na demanda dos produtos desse ramo; e a indústria leiteira, que atende a uma forte dinâmica produtiva regional.

Munidos dessa discussão a respeito do papel da indústria na formação da centralidade urbano-regional de Marabá, é importante notar que, para essa experiência, a indústria tem um peso significativo do ponto de vista de sua participação na composição da economia, mas também, do ponto de vista da estruturação socioespacial da rede urbana e do papel de centralidade dessa cidade; processo esse que se dá por relações diversas e complementares na região através de verticalidades e horizontalidades que aí se estabelecem.

Depois de discutir o processo de reestruturação urbana da Amazônia e o papel de Marabá enquanto uma cidade média do sudeste paraense, considerando a centralidade urbanoregional por ela assumida a partir da dinâmica de produção industrial, podemos ao final dessa dissertação afirmar que a realidade estudada apresenta algumas contribuições para o entendimento do tema das cidades médias, quando se considera a realidade brasileira. A primeira delas refere-se ao caráter polinucleado de sua estrutura urbana, revelado pela presença de diferentes centros, sendo três deles, principais (Marabá Pioneira, Cidade Nova e Nova Marabá), e três secundários (São Félix, Morada Nova e Quilômetro 6), cujo entendimento de sua produção exige do pesquisador o uso de abordagens que coloque como 
centro da análise o processo de formação socioespacial, e também o papel desempenhado pelas atividades comerciais e de serviços que estão voltados para atender tanto a dinâmica da cidade, propriamente dita, quanto a região em que ela se insere ${ }^{22}$. A segunda diz respeito ao papel político por ela exercido dentro da região, e que se revela, dentre outras formas, a partir da consolidação da dinâmica industrial de Marabá, principalmente aquela correspondente ao plano das horizontalidades, conforme discutido anteriormente.

\footnotetext{
${ }^{22}$ Ainda que não tenha sido o foco deste trabalho discutir o papel do comércio e dos serviços na centralidade urbano-regional de Marabá, essa afirmação pode ser feita com segurança, uma vez que está sustentada em dados que compõe relatório de pesquisa, elaborado sob a coordenação do Prof. Dr. Saint Clair Cordeiro da Trindade Junior, do qual ajudamos a escrever.
} 


\section{REFERÊNCIAS}

ALMEIDA, F. S. O entroncamento como forma espacial no urbano em área de fronteira: caso do km 6, Marabá-Pa. (Graduação em Licenciatura e Bacharelado em Geografia) Colegiado de Geografia, Universidade Federal do Pará, Marabá, 2002.

ALMEIDA, J. J. A cidade de Marabá sob os projetos governamentais. (Mestrado em História Econômica) - Faculdade de Filosofia, Letras e Ciências Humanas, Universidade de São Paulo, São Paulo. São Paulo, 2008.

AMARAL, M. D. B. O carvoejamento e sua insustentabilidade em Rondon do Pará. (Especialização em Formação de Especialistas em Desenvolvimento de Áreas Amazônicas) Núcleo de Altos Estudos Amazônicos, Universidade Federal do Pará, Belém, 2007

BECKER, B. Redefinindo a Amazônia: o vetor tecno-ecológico. In: CASTRO, I.E.; GOMES, P. C. C.; CORREAA, R. L. (Orgs.) Brasil: questões atuais de reorganização do território. $3^{\mathrm{a}}$ Ed. Rio de Janeiro: Bertand Brasil, 2005. (pp. 223-244)

Amazônia: geopolítica na virada do III milênio. Rio de Janeiro: Garamond, 2004.

. Amazônia. São Paulo: Ática, 1998.

. Fronteira e urbanização repensadas. In: BECKER, B; MIRANDA, M. MACHADO, L. O. (Orgs.) Fronteira amazônica: questões sobre a gestão do território. Brasília: Editora da Universidade de Brasília; Rio de Janeiro: Editora da Universidade Federal do Rio de Janeiro, 1990. (pp. 131-144)

CANO, W.; GUIMARÃES NETO, L. A questão regional no Brasil: traços gerais de sua evolução histórica. Desarollo Regional, Nuevos Desafios. Pensamiento Iberoamericano, Economia Política, n 10, Madri, Instituto de Cooperation Iberoamericana , p. 167-184, 1986.

COELHO, M. C. N. A CVRD e a (re) estruturação do espaço geográfico na área de Carajás (PA). In: CASTRO, I.E.; GOMES, P. C. C.; CORRÊA, R. L. (Orgs.) Brasil: questões atuais de reorganização do território. $3^{\text {a }}$ Ed. Rio de Janeiro: Bertand Brasil, 2005. (pp. 245-281)

COELHO, M. C. N. A CVRD e o processo de (re) estruturação e mudança na área de Carajás (PA). In: COELHO, M. C. N.; COTA, R. G. (Orgs.) Dez Anos da Estrada de Ferro Carajás. Belém: NAEA/UFPA, 1997. (pp. 51-78) 
COELHO, M. C. N.; MONTEIRO, M. A. (Orgs.) Mineração e reestruturação espacial na Amazônia. Belém: NAEA, 2007.

COELHO, M. C. N.; SIMONIAN, L.; FENZL, N. (Orgs.). Estado e políticas públicas na Amazônia: gestão de recursos naturais. Belém: Cejup: UFPA-NAEA, 2000.

COMPANHIA VALE DO RIO DOCE; DIAGONAL URBANA. Diagnóstico integrado em socioeconomia para o sudeste do Pará. Belém: CVRD, 2007.

CORREAA, R. L. Estudos sobre a rede urbana. Rio de Janeiro: Bertrand Brasil, 2006.

DIAS, C. V. Marabá: centro comercial da castanha. Revista Brasileira de Geografia, Rio de Janeiro, ano 20, n. 4, p. 383-425, 1958.

EMMI, M. F. A oligarquia do Tocantins e o domínio dos castanhais. Belém: UFPA/NAEA, 1999.

EMMI, M. F.; ACEVEDO MARIN, R. Crise e rearticulação das oligarquias no Pará. Revista do Instituto de Estudos Brasileiros. São Paulo, nº 40, pp. 51-68, 1996.

FERNANDES, B. M.; MARTIN, J. Y. Movimento socioterritorial e globalização: algumas reflexões a partir do caso do MST. Lutas Sociais (PUCSP), São Paulo, v. 12, 2004.

GODELIER, M. Formação econômica social. In: Enciclopédia Einaudi. Vol. 7. Portugal: Imprensa Nacional/Casa da Moeda, 1986.

GOVERNO DO PARÁ. Secretaria Executiva de Estado de Planejamento, Orçamento e Finanças (SEPOF). Estatística Municipal de Marabá. Pará, 2007.

MACHADO, L. O. Urbanização e mercado de trabalho na Amazônia brasileira. Cadernos IPPUR, Rio de Janeiro, Ano XIII, Nº 1, 1999.

MARTINS, J. S. Fronteira: a degradação do Outro nos confins do humano. São Paulo: Hucitec, 1997.

MONTEIRO, M. A. A siderurgia e a produção de carvão vegetal no corredor da estrada de ferro Carajás. In: COELHO, M. C. N.; COTA, R. G. (Orgs.) Dez anos da estrada de ferro Carajás. Belém: UFPA/NAEA; Editora: Gráfica Supercores, 1997. (pp. 183-221) 
MORAES, A. C. R. Território e história no Brasil. São Paulo: Annablume, 2005

. Território, poder e justiça: comentários a partir da experiência brasileira. In: Kritsch, Raquel; Ricupero, Bernardo. (Org.). Força e Legitimidade: novas perspectivas? São Paulo: Humanitas, 2005, p. 113-129.

. Bases da formação territorial do Brasil: o território colonial brasileiro no "longo" século XVI. São Paulo: Hucitec, 2000. (Estudos Históricos; 41)

MORAES, A. C. R; COSTA, Wanderley Messias da . Geografia Crítica. A Valorização do Espaço. 4a . ed. São Paulo: Hucitec, 1999. 197 p.

OLIVEIRA, J. A. Espacialidades urbanas como urbanização da sociedade: as cidades e os rios na Amazônia brasileira. OLIVEIRA, M. P; COELHO, M. C. N; CORRÊA, A. M. O Brasil, a América Latina e o Mundo: espacialidades contemporâneas (II). Rio de Janeiro, 2008.

PEREIRA, J. C. M. Importância e significado das cidades médias na Amazônia: uma abordagem a partir de Santarém (PA). (Mestrado em Planejamento do Desenvolvimento) Núcleo de Altos Estudos Amazônicos, Universidade Federal do Pará, Belém, 2004.

PREFEITURA DE MARABÁ. Diagnóstico do Plano Diretor de Marabá. Marabá, 2006.

RIBEIRO, M. A. A rede urbana amazônica - da rede dendrítica à configuração de uma rede complexa. In: SPOSITO, Maria Encarnação B. Urbanização e cidades: perspectivas geográficas. Presidente Prudente (SP): UNESP, 2001.

SANTOS, M. A urbanização brasileira. $5^{\text {a }}$ ed. São Paulo: Edusp, 2005. (Coleção Milton Santos; 6)

. Da totalidade ao lugar. São Paulo: Edusp, 2005a. (Coleção Milton Santos; 6)

Por uma economia política da cidade: o caso de São Paulo. São Paulo: Educ, 1994 
SANTOS, M.; SILVEIRA, M. L. Brasil: território e sociedade no início do século XXI. Rio de Janeiro: Record, 2001.

SILVEIRA, M. L Globalização, trabalho, cidades médias. GeoUERJ, Revista do Departamento de Geografia da UERJ, Rio de Janeiro, nº 11, pp. 11-17, 2002.

SOJA, E. Geografias pós-modernas: a reafirmação do espaço na teoria social crítica. Rio de Janeiro: Jorge Zahar Editor, 1993.

SPOSITO, M. E. B.Cidades médias: reestruturação das cidades e reestruturação urbana. In: SPOSITO, M. E. Cidades médias: espaços em transição. São Paulo: Expressão Popular, 2007. (pp. 233-253)

O chão em pedaços: urbanização, economia e cidades no Estado de São Paulo.

Presidente Prudente: [s.n.], 2004. (Tese de Livre Docência)

As cidades médias e os contextos econômicos contemporâneos. In: SPOSITO, M. E. B. (Org.). Urbanização e cidades: perspectivas geográficas. São Paulo: Expressão Popular, 2000. (pp. 609-643)

TOURINHO, H. L. Z. Planejamento urbano em área de fronteira econômica: o caso de Marabá. (Mestrado em Planejamento do Desenvolvimento) - Núcleo de Altos Estudos Amazônicos, Universidade Federal do Pará, Belém, 1991.

TRINDADE JR., S. T. C. Grandes projetos, urbanização do território e metropolização na Amazônia. In: X Encontro de Geógrafos da América Latina, 2005, São Paulo. Anais... São Paulo: USP, 2005.

TRINDADE JR., S. C.; RIBEIRO, R. Marabá: novos agentes econômicos e novas centralidades urbano-regionais no sudeste paraense. In: TRINDADE JR., S. C. et al. (Orgs.) Pequenas e médias cidades na Amazônia. Belém: Federação de Órgãos para Assistência Social e Educacional/FASE; Instituto de Ciências Sociais Aplicadas/UFPA; Observatório COMOVA, 2009. (pp.333-359)

TRINDADE JR., S. C.; PEREIRA, J. C. C. Reestruturação da rede urbana e importância das cidades médias na Amazônia oriental. In: SPOSITO, M. E. Cidades médias: espaços em transição. São Paulo: Expressão Popular, 2007. p. 313-342.

VICENTINI, Y. Cidade e História na Amazônia. Curitiba: UFPR, 2004. 
YOSHIOKA, R. Avaliação de implantação de núcleo urbano na Amazônia: exemplo de Nova Marabá-Pará. (Mestrado em Geografia Humana) - Faculdade de Filosofia, Letras e Ciências Humanas, da Universidade de São Paulo, São Paulo, 1986.

http://www.ibge.gov.br/mapas_ibge/ (acessado em 22 de abril de 2009) 